\title{
TRANSNATIONAL SPACES, TRANSITIONAL PLACES: MUSLIMNESS IN CONTEMPORARY LITERARY IMAGINATIONS
}

\author{
A Dissertation \\ presented to \\ the Faculty of the Graduate School \\ at the University of Missouri-Columbia \\ In Partial Fulfillment \\ Of the Requirements for the Degree \\ Doctor of Philosophy \\ by \\ NERIMAN KUYUCU \\ Prof. Karen Piper, Dissertation Supervisor \\ MAY 2020
}


(C) Copyright by Neriman Kuyucu 2020

All Rights Reserved 
The undersigned, appointed by the dean of the Graduate School, have examined the dissertation entitled

\section{TRANSNATIONAL SPACES, TRANSITIONAL PLACES: MUSLIMNESS IN CONTEMPORARY LITERARY IMAGINATIONS}

presented by Neriman Kuyucu

a candidate for the degree of Doctor of Philosophy

and hereby certify that, in their opinion, it is worthy of acceptance.

Professor Karen Piper

Professor Nathan Hofer

Professor Christopher Okonkwo

Professor Lynn Itagaki 
To all the souls who have found home in spaces in between 


\section{ACKNOWLEDGEMENTS}

I am deeply indebted to everyone who has contributed to this dissertation over the past few years. To my supervisor and mentor, Karen Piper, I am forever grateful. Thank you for the patience, care, and intelligence with which you have read and discussed several drafts and chapters. I would also like to extend my deepest gratitude to my committee, Christopher Okonkwo, Nathan Hofer, and Lynn Itagaki for their assistance and suggestions throughout my project.

This dissertation would not have been completed without the support of my friends and family near and far. To Aylin, Burçin, and Radka, I am grateful for all the invaluable moments of laughter, reflection, and fun. Thank you for always being there for me, no matter how many miles separate us. Thank you to Kristin, Carley, Becky, and Burcu for your companionship, support, distraction, and commiseration.

Special thanks to Tristan who has kept me grounded and adventurous. Thank you for believing in me even when I did not.

To my parents and my brother Mehmet, I am exceedingly grateful for your unlimited support. To my father, thank you for always believing in me and supporting all the decisions I've made. To you, I owe everything.

To my cat Venus, I am thankful for all the cuddles and the constant love.

To my younger self, I am eternally grateful for working relentlessly to make all my dreams a reality. 


\section{TABLE OF CONTENTS}

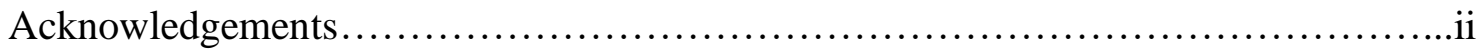

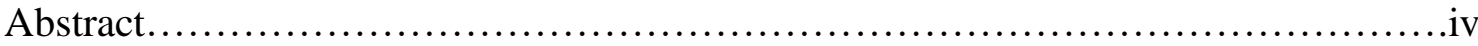

Introduction: The Intersections of Muslim Writing and Muslim Diaspora..............1

Chapter 1. Towards a New Mode of Reading Muslim Diasporic Writing:

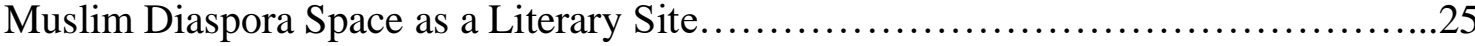

Chapter 2. Recovering Voices and Creating Muslim Spaces in Laila Lalami

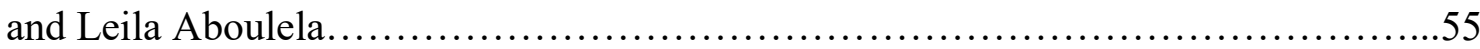

Chapter 3. Muslimness and The Politics of a Homing Desire: Abu-Jaber, Shafak, and Jarrar....

Chapter 4. The Convergence of Islam, Feminism, and Queerness in Muslim Diasporic Writing: Aboulela, Janmohamed, and Tanaïs.

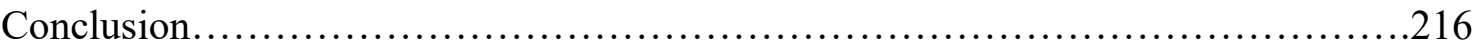

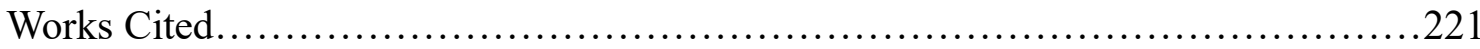

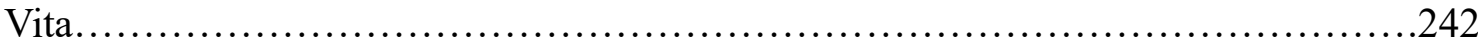




\begin{abstract}
This dissertation focuses on contemporary literature in English produced by writers of Muslim origin. My study analyzes Laila Lalami's The Moor's Account (2014), Leila Abuela's The Kindness of Enemies (2015), Diana Abu-Jaber's Crescent (2003), Elif Shafak's The Saint of Incipient Sanities (2004) and Randa Jarrar's A Map of Home (2007), and Leila Aboulela's Minaret (2005), Shelina Janmohamed's Love in a Headscarf (2009), and Tanwi Nandini Islam's Bright Lines (2015) to explore and illuminate the ways in which Muslim diasporic subjectivity is being reconfigured in contemporary literary imaginations. Guided by developments in Muslim literary studies, postcolonial and diaspora theories, this dissertation examines, from an interdisciplinary perspective, the particular conjunctures of literature, Muslimness, displacement, and belonging within the new analytic framework of Muslim diaspora space. This project seeks to move beyond the set of discourses - radicalization vs. secularization; Islamism vs. liberalism - that have defined Muslimness to highlight alternative positionalities in between. My analyses of the chosen texts through the lens of Muslim diaspora space, I argue, shift the focus from the preconceived notions about the authors' positionality as Muslim to the ways in which they create complex characters that represent the variety of Muslim discourses and practices. Rather than focusing on such over-asked questions as "Is the text Islamic or secular?" and "Western or Muslim?," Muslim diaspora space as a mode of analysis highlights how the writers negotiate the concepts of Islamic vs. secular and Muslim vs. citizen by redefining "Muslimness" as well as "western-ness."
\end{abstract}


Introduction: The Intersections of Muslim Writing and Muslim Diaspora Immediately after the current U.S. administration's executive order on the travel ban that restricted immigration from seven Muslim countries in 2017, more than fifty literary agents from various agencies in North America issued a collective open call for submissions from Muslim writers. "Like so many of you," their statement read, "we are gravely alarmed by the present administration's recent broad ban on refugees and immigrants from Muslim countries [...] fear[ing] the message sent by these bans to people within our country and to those outside of our borders." The literary agents openly acknowledged the impact of the market forces on cultural production, consumption, and circulation. "This is our open call for stories that will bring increased understanding, tolerance, empathy and compassion in the world," they added, "We all agree that the current political climate demands a need for a greater presence of authors of Muslim heritage in the book marketplace" (Gore 2017). The concerns of the literary agents speak to the various ways in which Muslim populations have, since $9 / 11$, have wrestled with the discursive constructions of Muslimness, what it means to be Muslim in the Global North: a key concept that underpins the entirety of this project that examines the intersections of contemporary Muslim writing and Muslim diaspora.

"The Muslim ban" has gone into effect at a time when Muslims are becoming the fastest growing segment of the diasporic population in the Global North.1 The executive order has demonstrated once again that as the Muslim diaspora in the United States and Europe continues to grow, so do political and legislative efforts to resolve the "problem"

\footnotetext{
${ }^{1}$ See Lipka (2017) and Mohamed (2018) for recent estimates.
} 
of Islam. To this end, the complexity of the issues surrounding Muslim identities, including Islamist extremism, the flux of refugees, integration, flows of labor, resistance, and the incompatibility of Islam with Western democratic principles, has frequently been covered by mass media and investigated in academic circles. However, broader theoretical questions about the formation of Muslim subjectivity2 in the diaspora and about literary engagements with the notions of Muslimness in particular remain understudied. This project broadens the perspective of the various ways in which "Muslim diaspora" can be theorized and used as an analytic tool to read narratives produced by writers of Muslim origin from the Muslim Middle Eastern/South Asian/North African3 diasporas.

While the bulk of the studies on the notions of Muslim diaspora have examined its usefulness as a conceptual tool through a social science perspective, this project conceptualizes Muslim diaspora space through a postcolonial cultural studies method. It acknowledges the limitations of data-based research on the Muslim diaspora and explores the ways in which literature can contribute to our understanding of Muslim diaspora and the positionality of Muslims within it. In doing so, it seeks to remedy the conceptual and

\footnotetext{
2 I use "subjectivity" in Brah's terms as "the site of processes of making sense of our relation to the world" which can also be "the modality in which the precarious and contradictory nature of the subject-in-process is signified or experienced as identity" (Brah 1996, p. 123).

3 The term "the Muslim Middle Eastern/South Asian/North African diasporas" refers to the geography of Islam as explored in Alsultany and Shohat's Between the Middle East and Americans (2013). Alsultany and Shohat use the term "the Middle East" to "echo this common usage of the term, however inaccurate, to include North Africa as well, since within the public sphere 'the Middle East' does tend to 'cover' the region of North Africa, including in academic organizations, for example, The Middle East Studies Association." Alsultany and Shohat's use of "the Middle East" thus "alludes to the idea of the Middle East as signifying a broad geographical spectrum, while acknowledging that it is a problematic rubric." "In this sense," they add, "while South Asia might appear to be outside the scope of a volume dealing with Middle Eastern / North African diasporas, the current cultural politics make it necessary to address the ways in which Islamic Asia (Pakistan, Bangladesh, Kashmir, Indonesia, etc.) and the Middle East become conflated" (21). I use "Muslim diaspora" in this context throughout this project.
} 
methodological gaps in diaspora studies, as well as literary studies. This study thus analyzes the current scholarship on diaspora and Muslimness, specifically investigating questions of who can represent and can speak for Muslims in the current political climate, along with concerns with cultural racism, anti- immigration rhetoric, and the notion of Muslimness that is currently synonymous with threat and terror.

\section{From Data-Based Research to Literary Analysis}

The role of imagination and self-representation has not been fully articulated in studies on diasporic Muslim populations. In Writing Across Worlds (1995), Paul White argues that literary sources in migration and diaspora studies have often been perceived as "tangential sources," sources that have often been relegated to the periphery. "Such an endeavour," he explains, "has traditionally made social scientists uneasy" because "much of the research has been operated at an objective level with a concentration on statistical data sources" (9). In Modernity at Large (1998), Arjun Appadurai, too, is concerned with the scholarly tendency to view literary texts as secondary sources in studies of diaspora and migration. "Like the myths of small-scale society as rendered in anthropological classics of the past," he writes, "contemporary literary fantasies tell us something about displacement, disorientation, and agency in contemporary world" (58). In other words, imagination and self-representation serves as a tool through which we can illuminate the cultural processes of globalization and diasporization. In a similar vein, Françoise Král (2009) emphasizes identity as a conceptual and analytical framework that can be studied "rather scientifically and quantified in terms of integration." Self-representation, however, is acknowledged as an essential parameter of identity definition and is more 
subjective and therefore difficult to grasp (3). Drawing on Benedict Anderson's concept of imagined communities, Joel Kuortti (2007) develops the term "imagined diasporas" to explain: "that a given diaspora comes to be seen as a community is the result of such a process of imagining, at the same time creating new marginalities, hybridities and dependencies" (4). In this spirit, literature shapes theoretical formations and the world and is also simultaneously shaped by these elements.

As Azade Seyhan (2001) aptly puts it, "ultimately, every theory of postcolonial, transnational, or diasporic literature and art is most convincingly articulated and performed by works of literature and art themselves" (7). Following Seyhan, Kuortti notes, "in conferences on post-colonial literatures, it has always been most rewarding to hear and talk with writers of those literatures." He underscores imagination as a key social force. "The same goes for diaspora," he adds, "[which] does not emerge as a mere sociological fact, but it becomes what it is because it is said to be what it is" (5). In the same vein, literary expressions of contemporary Muslim diasporic formations offer critical insights into complex narratives of dislocation/location and Muslim diasporic experience in the twenty first century.

The paucity of scholarship on Muslim diasporic writing directly reflects the complexity of the concepts of "diaspora," "Muslim diaspora," and "Muslimness." Thus, I situate Muslim writing in two significant ways: in relation to the notions of Muslim diaspora, which I will re-conceptualize as "Muslim diaspora space," a framework of analysis that transgresses the nationalist and religious methodologies commonly used in studies on Muslim diaspora and Muslim writing; and in relation to "Muslimness" as a 
contradictory field of meaning. I argue that Muslim diaspora space, like all diasporic spaces, 4 can refer to a social formation in process and be used as a helpful theoretical lens that can highlight a literary site that Muslim writes are creating within the current politics of representation. As an analytic tool that is theoretically embedded, Muslim diaspora space highlights the role of imagination and the ways in which the works of literature by Muslim writers inform and are informed by the sociopolitical context.

\section{The Terrain of Diaspora Studies}

In the last two decades, "diaspora" has become a catchword in the fields of political science, sociology, anthropology, and literary studies. Originally used in reference to historical Jewish, Greek, and Armenian dispersions, scholarly discussions have, since the postmodern turn in the 1990s, presented a shift in focus from historical studies of diaspora as a site of exile and yearning for the homeland towards a more heuristic interpretation of the concept. This shift from historicity to narrative, deterritorialization, and identity as a fluid construct has revolutionized diaspora studies, paving the way for an exploration of diasporas as dynamic processes that reflect a wider shift in the experience of displaced subjects. However, scholarship on the Muslim diasporas has predominantly examined its scope and limitations through a historical, social science perspective.

Although studies on Middle Eastern diasporas 6 have increasingly used a postcolonial and cultural studies lens, little work has approached the notions of Muslim

\footnotetext{
4 Werbner (2000) examines the close link between diaspora as a social formation and its representation and how the reality of diaspora is both "representational" and "material."

${ }^{5}$ See Cohen (1971), Tölölyan (1991), and Sheffer (2003).

6 As seen in Alsultany and Shohat (2013) and Gorman and Kasbarian (2015).
} 
diaspora from a pluralistic cultural studies approach that transgresses the dichotomy between the homeland and the host society, and between the religious and the secular. While much of the literature examines the categories of Muslim writing and Muslim diaspora as disparate fields, my project examines the particular conjunctures of literature, Muslimness, displacement, and belonging within the context of diaspora. As an interdisciplinary project, this study thus contributes both to the field of literary studies and diaspora studies by interrogating the literary and sociopolitical implications of making meaning of a Muslim self in the diaspora in the post- 9/11 context.

"Muslim diaspora" has been widely used in discussions in media and academic discussions, often with little reflection on its analytic value and theoretical implications. As sociologists and anthropologists Sarah Albrecht, Tobias Boos, and Veronika Deffner (2016) state, "such a blithe use of the label makes two major hazardous assumptions: first, it implicitly states an ontic category of self-description; and second, it supposes the existence of a scholarly consensus on the appropriateness of its use. Yet neither of these assumptions is accurate" (1-2). In mass media, Muslim communities are often defined within the confines of an ethno-religious framework that highlights Muslim identity as an anomaly, a perpetual marker of otherness that needs to be erased for full integration whereas scholarly discussions have predominantly used descriptive modes of data-based research. Many excellent empirical studies 7 have investigated how the Muslim diaspora populations carve out a niche for themselves in western public spheres as contemporary 
citizens. These studies, however, use the terms "Islamic" and "Muslim" diaspora in reference to various forms of religious expressions and offer little theoretical discussion on the concept as a useful framework of analysis.

Moreover, the small number of studies that examine the potentialities of Muslim diaspora has focused either on the axis of political Islam or on the traditional model of diaspora that places the epistemological emphasis on ethno-national categorizations, historicity, and traumatic realities of dispersion from a given homeland. Political scientist Gabriel Sheffer (2002; 2006), for instance, frames Muslim diaspora as a concept that is overstretched and thus has become devoid of importance. In Sheffer's formulation, "Muslim diaspora" by definition does not correspond to the main features of diasporas: "the homeland, the host society and the ethno-national cluster," (Safran 1991) as primordial constituents of the process of diasporization. Since Muslimness as a marker of identity does not imply a shared sense of ethno-national consciousness in this context, Sheffer suggests that "there is no doubt that [Muslims'] main connections are with their countries of origin rather than with an abstract Muslim World or a Muslim Diaspora" (9). In this context, Muslim communities as a group cannot form a cohesive diaspora; instead, they can only be organized in terms of their ethno-national characteristics, i.e., "Palestinian diaspora," "Lebanese diaspora," "Turkish Diaspora."

However, other sociologists such as Peter Mandaville (2001), Rivka Yadlin (2002), and Christopher Schumann (2007) have explored possible meanings for Muslim diaspora by placing transnational Islam and the ummahs at its center. For instance, Yadlin

8 The Arabic term for "community." The term ummah appears in the Koran in discussions of the 
discusses the notion of Muslim diaspora as an "adopted nationality" (224) and connects it with transnational Islam, which undergirds the politicization of the ummah to demand an Islamic state (226), a state that is theologically Islamic. This type of a unified Muslim identity has its roots in the decolonization efforts that followed political independence in the Middle East and South Asia. As Arun Kundani (2014) writes:

For the Muslim brotherhood in Egypt and the JI in Pakistan, the answer [during the postcolonial period] was to be found in turning Islam into a form of identity politics. It was as Muslims, rather than nationals of a colonially defined territory, that a sense of shared belonging was to be established and a more fundamental breach with European cultural domination. (36)

The notion of a global Muslim identity maintains the politicization of the ummah, often framed by the prescriptive and restrictive Islamic order. As sociologists have demonstrated9, Islamist movements have spread quickly in the Global North due to the increasing number of transnational networks and activities, including migration and the internet. Since The Satanic Verses controversy in particular, radical groups such as alMuhajiroun and Hizb ut-Tahrir (HT) have targeted young Muslims who live in western countries for recruitment for whom, as Kundnani explains, "the idea of identifying with the global ummah proved an attractive third alternative to either assimilating into a racist society or following the inherited religo-cultural traditions of their parents" (37). Up until the first and only special issue on Muslim diaspora "Conceptualising Muslim Diaspora" unity. 
was published in Journal of Muslims in Europe in 2016, these politically charged diasporic networks and movements have drawn the most attention in the studies on Muslims in the diaspora.

From Matthias Gebauer and Shadia Husseini de Araújo's case studies in South America that examine transnational Muslim Blackness to Patrick Eisenlohr's reflection on "diaspora" as a category of both practice and analysis, the collection of essays in “Conceptualizing Muslim Diapora" successfully broadened the scope of Muslim diaspora studies and built on the few theoretical discussions on the concept.10 These theoretical engagements, albeit small in number, reveal the potentialities of Muslim diaspora as a framework of analysis that can contribute to our perception of what it means to be a Muslim in the Global North, particularly in the current political climate when diasporic Muslim subjectivity has taken on critical dimensions.

\section{The Genealogy of Muslim Writing}

The semantic ambiguity that characterizes the discourse on Muslim diaspora in the twenty-first century shapes the contours of contemporary Muslim fiction. Studies that examine works of literature produced by writers of Muslim origin tend to use the terms "Muslim" and "Islamic" interchangeably, without little to no theoretical reflection on the usefulness and/or implications of the concepts. Without a doubt, discussions on Islamic fiction offer critical insight into the trends and patterns that are emerging within the field of contemporary Muslim literary studies. The debate on Islam and fiction, however, often 
uses heritage and origin as a way to preserve ethnic and national identity, raising a set of critical questions and concerns regarding Muslimness and diasporic Muslim subjectivity. What is constituted as Muslim writing? How can we define Muslim fiction? Can nonMuslim writers such as Don DeLillo, Ian McEwan, and John Updike contribute to the genre of Muslim fiction? Is it only practicing Muslims who can be studied under the rubric of Muslim writing? What is the pertinence of branding disparate texts produced by writers of Muslim origin as "Muslim narratives"? What can be gained from a discussion of the emergence of "a global Muslim literary imagination"? This project addresses these interlocking questions within the framework of Muslim diaspora space in order to demonstrate the ways in which Muslim diaspora space as a mode of analysis shifts the focus to how migrants and citizens of Muslim origin make sense of chaos and ongoing shifts that characterize contemporary experience. Such crucial questions that inform the construction of diasporic Muslim subjectivity are understudied today.

In her collection of interviews with contemporary "writers of Muslim heritage" British Muslim Fictions (2011), Claire Chambers asks British Bengali writer Tahmima Anam about the emerging category of Muslim writing, as well as about Muslim Writers Awards. "I really don't know a lot about Muslim writing," Anam responds, "I know Muslim writers and I know writers who write about Islam, but I really don't know what 'Muslim writers' means, and I've never been to any of the Muslim Writers Awards events." Reflecting on the debate about which countries the Man Asian Literary Prize should include, she notes, "All of these are concepts or categories that we have which need to be questioned, but they can also be useful (165). Similarly, when asked the same 
question, writers such as Leila Aboulela, Laila Lalami, and Robin Yaqin-Kassab who are often branded as Muslim writers underline the urgency to investigate the meaning(s) of Muslim writing, pointing to the burden of representation the category itself implies. In this context, Chamber's anthology proves to be crucial, as it provides insight into the constituents of Muslim writing as a literary category. Her collection brings together a wide range of writers, "from a broadly imagined, absorbent 'Muslim World' to shed light on each other," (14) from Tariq Ali and Hanif Kureishi to Abdulrazak Gurnah and Fadia Faqir. In their insightful interviews with Chambers, the British writers discuss their work, intertextuality, their relation to Muslimness, as well as media and literary representations of Muslims. A study of the interviews highlights both the challenges and limitations of defining "Muslim writing" in the current sociopolitical context where "Muslim" is conflated with "terror," "foreign," and "oppressed."

Since Muslim Writers Awards was founded—in partnership with Penguin Books, Puffin Books, and the Institute of English Studies - in 2006, many scholars and critics have offered various theories of what constitutes the broad canvas of Muslim writing. Three major trends dominate the discourse on Muslim narratives today. The first and perhaps most prominent trend "Islamic fiction" is characterized by commitment to Islamic theological tradition. Islamic Writers Alliance, a literary Muslim organization founded in 2005 in the U.S., defines Islamic fiction as "creative, imaginative, nonpreachy fiction books written by Muslims and marketed primarily to Muslims," which "may be marketed to mainstream markets, too." The works of Islamic fiction are guided by didacticism in that the purpose is to teach the reader "something positive about Islam." 
Moreover, Islamic fiction writers, according to IWA, refrain from using "harmful content" which includes "vulgar language, sexually explicit content, unIslamic practices that are not identified as Islamic, or content that portrays Islam in a negative way." In this sense, Islamic fiction is similar to, what The Muslim News calls, "halal writing" (qtd. In Chambers 103): a form of creative writing that avoids content that can be deemed as unIslamic. Novels such as The Echoes Series (2006) by Muslim American writer Linda Jamilah Kolocotronis, Many Poetic Voices, One Faith written by the members of IWA, Leila Aboulela's Minaret (2005) all of which present a deeper level of spiritual and theological connection to Islam are included under the rubric of halal Islamic fiction. While Islamic fiction principally excludes non-Muslim writers, the second trend subsumes narratives about Muslims written by non-Muslims under the category of Muslim writing. Texts that engage with representations of Muslims produced by nonMuslim writers such as Don DeLillo, Ian McEwan, and Martin Amis or by neo-orientalist writers such as Ayaan Hirsi Ali, Irshad Manji, and Ibn Warraq are studied as an integral part of Muslim narratives. The last, and the most favorable for my own purposes in this project, trend moves away from the emphasis on Islam as religion and towards Islam as culture and heritage, thereby bringing into focus an insider's perspective. Mohja Kahf's term "literary Muslimness" as well as Claire Chambers's reference to "writers of Muslim heritage" emerge out of this trend with its emphasis on a shared Islamic heritage. This approach to Muslim writing is relatively new and certainly requires more exploration. Fundamental in this trend is the shift in focus from Muslim writing that is either purely Islamic or purely secular towards a perception of Muslim writing that prioritizes the 
plurality of an insider's perspective without overlooking broad contextual differences. Unlike Islamic fiction and the second trend that is too broad in its definition, Muslim writing as a category that emerges out of a shared cultural and religious heritage allows us to examine Muslim narratives as complex texts rather than a mere scale of piety and religiosity as well as to privilege the diverse voices of those who identify as Muslim.

The aforementioned trends point to the proliferation of discussions on Muslim writing in the last decade, but Amin Malak's study Muslim Narratives and the Discourse of English (2004) was the first to offer a coherent exploration of Muslim writing as a broad literary category. Muslim Narratives was groundbreaking in that it decentralized non-Muslim writers who write about Muslims for the first time within the discourse of English literary studies. Malak prioritizes authors who "have experienced Islam firsthand for an extended, formative period... who have been influenced by it to such a degree that it has represented a significant inspirational source for them... who are producing their narratives in English." Malak's definition is premised on Islam as a primary identity signifier that "could rival, if not supersede, their class, gender, race, or ethnic affiliation" (3). This repositioning of the term "Muslim" allows him to set forth a case for a concept of Islam that is shaped and reshaped by writers' idiosyncratic relations to their Islamic heritage. Following Malak, Claire Chambers (2011) employs the term "writes of Muslim heritage" to draw a distinction between Muslim writing and, what she aptly calls, "the schoolteacher's term Islamic literature" (10). Unlike Malak, however, Chambers is not concerned with the religiosity of the writers; instead, her interest lies in the ways in which writers of Muslim heritage are to an extent influenced by "Islamicate civilizations" (11) 
defined as cultural aspects of Muslimness. She uses the term, "writers of Muslim heritage" to highlight and deconstruct "stereotypical representations of 'Muslimness' as a unitary, unchanging identity, and to eschew problematic judgements about whether or not writers are sufficiently religious" (10). In this context, the discursive emphasis moves away from Islam as an ideology towards the processes by which individual writers who feel a connection to their Muslim heritage make meaning of their multifaceted identities. In Writing Muslim Identity (2012), Geoffrey Nash further builds on Malak's formulation. Unlike Chambers, however, Nash takes a historicist approach to draw a trajectory of Muslim writing in a global context to show Islam's positioning as "the Western's Other" in contemporary diasporic writing. He defines Muslim writing as a form of prose "that takes Islam or Islamic religious belief and cultures as its focus" (5). He thus broadens the canvas of Muslim writing through his examination of the myriad ways in which Muslim identity has been represented by a wide array of writers, from non-Muslim writers such as Don DeLillo, Ian McEwan, and John Updike to neoorientalist writers like Irshad Manji and Taslima Nasreen, as well as writers who identify as Muslim, e.g., Laila Halaby, Mohsin Hamid, and Naguib Mahfouz. Nash does not intend to develop a working definition of Muslim writing per se. Instead, he offers an indepth synthesis of various representations of Muslim identity in contemporary global literature. Rehana Ahmed, Peter Morey and Amina Yaqin in their introduction to Culture, Diaspora, and Modernity in Muslim Writing (2012) follow a similar trajectory and pose critical questions about the epistemology of Muslim writing that warrants emphasis. "Cannot Muslim writing be understood also being produced by authors hailing from a 
Muslim cultural background," they ask, "for whom God and faith may have receded entirely from their sense of themselves and their affiliations in the world?" (3). Although Ahmed, Morey, and Yaqin emphasize that a wide range of positions "combining faith and doubt, materialism and spirituality, individualism and community" lie between secular Muslim writers, i.e., Salman Rushdie and Leila Aboulela, their primary goal is to investigate the discursive power of texts rather than authorship.

In particular, Ahmed, Morey and Yaqin highlight the ways in which Muslim and non-Muslim texts that offer representations of Muslims are intertwined within the context of diasporic writing. "Muslim and non-Muslim texts are mutually shaping and cannot be sealed off from one another," they write, and non-Muslim texts "define the territory for much Muslim identified writing and so have earned their place in the story (5). While the importance of studying all literary representations of Muslims, whether positive or negative, cannot be challenged, I find it problematic to ascribe any power and agency to the narratives about Muslims written by non-Muslims that essentially work to reduce Muslim identity into a fixed object.

The majority of literary texts about Muslims by celebrated non-Muslim writers such as Don DeLillo, Ian McEwan, and John Updike operate within a paradigm that, as Nash (2012) claims, "does not have the semantic tools to penetrate the mysteries of Muslim identity" (108). The separatist ideologies that underpin such texts are pervasive and already entrenched in the hegemonic discourse. For instance, Ian McEwan's protagonist in Saturday (2005) ponders on the threat of Islam that Euro-American society encounters, imagining the ways in which the society would have to operate differently 
under the Islamic State. "As a Londoner," the protagonist narrates, "you could get nostalgic for the IRA[...] Radical Islamists [...] want the perfect society on earth, which is Islam [...] If everyone is sure to end up happy for ever, what crime can it be to slaughter a million or two now?" (34). It is clear that McEwan's novel hinges on the post 9/11 fear and anxiety surrounding Islam. John Updike's The Terrorist (2006) slightly diverges from McEwan's approach in that it is predominantly concerned about the construction of the Muslim figure as fundamentalist.

Although both texts operate within the hegemonic discourse that circulates the clichés about Islam, Ahmed, Morey and Yaqin argue that external perspectives of nonMuslim writers contribute to the category of Muslim writing because "whether sympathetic or hostile" such works "serve[d] to fix and establish a way of seeing—one might almost call it a structure of feeling-Muslims in the West" (5). The claim that narratives that center on Islam and Muslims frame the discourse on Muslimness is certainly valid. However, the important question that I ask in this project is this: How can we shift the discursive focus from the perception of Muslims that perpetuates the stereotypical image of the Muslim figure to how Muslim writers are defining and redefining the notions of Muslimness?

Writer and activist Tariq Ali aptly refers to neo-orientalist writers that revive the orientalist tropes as "belligetari" who merely capitalize on anti-Muslim stereotypes (qtd. In Chambers, 45-6). These neo-orientalist narratives tend to underscore Islam as the tyrannical force behind the supposed dehumanization, oppression, and backwardness of Muslims. As I explore throughout this project, the proliferation of representations of 
Muslims in literature speaks to the direct correlation between media trends that follow terror-related incidents like 9/11 and 7/7, as well as western readership's desire to "decode the mysteries" of Muslims. The hostile representations that have dominated the literary discourse appeal to a certain western audience, in Chambers's words (2010), "saying things about Islam that the mainstream wants to hear" ("Multi-Culti" 3891). Within this context, neo-orientalist and non-Muslim writers who play on the reductive tropes about Islam tend to achieve marketplace success and thus shape the discourse. However, writers who identify as Muslim_ - Leila Aboulela, Kia Abdullah, Laila Lalami, Elif Shafak, and Tanwi Nandini Islam, among others - investigate the multifaceted nature of Muslimness, but "they do not enjoy equal exposure" (Morey 28).

The popularity of neo-orientalist narratives about Muslims also runs the risk of feeding into the culturalist approach that views Muslims as "the problem." As Peter G. Mandaville argues in Traditional Muslim Politics (2001), the confrontation between Islam and the west, though critically significant, has "overdetermine[d] our perceptions of Islam" to an extent that "crucial contestations and negotiations within Islam go unnoticed" (2-3). If we continue to highlight narratives that construct an image of Muslims as oppressed and/or fundamentalist, the complexity of the processes by which Muslims make sense of their Muslimness in the diaspora goes unnoticed. The field of literary studies then is in need of a new mode of reading Muslim narratives that can fuel a shift in focus from the debate on Islam as a theologized vision to lived and/or imagined experiences of Muslimness as narrated by those who, in Malak's words, "project the culture and civilization of Islam from within" (2). As briefly discussed earlier, Mohja 
Kahf acknowledges the urgency to explore this shift and offers an alternative to the various definitions of Muslim writing explored here thus far - an alternative, if expanded on, can introduce a new way of reading and studying texts about Muslims.

In "Teaching Diaspora Literature: Muslim American Literature as an Emerging Field," (2010) Mohja Kahf poses a challenging question: "Is there such a thing as Muslim American literature (MAL)?” (163). In this brief exploratory essay, Kahf seeks to delineate the contours of what could be called Muslim-American Literature. In doing so, she offers an overview of the literary trends that have characterized, what she calls, "literary Muslimness" in the U.S. At the core of Kahf's term "literary Muslimness" is a significant shift in focus from "levels of commitment or practice" towards a notion of "Muslim authorship" that highlights an individual approach to Muslim writing. Kahf underscores the interplay of the notions of Muslimness and literature in her definition of literary Muslimness as "a cultural, not religious, notion of Muslim that is relevant" (167). She divides the concept of literary Muslimness into four different categories: The Prophets of Dissent, Multi-ethnic Multitudes, New American transcendentalists, and New Pilgrims. In doing so, she narrows the scope of Muslim writing as a category while simultaneously broadening the spectrum of Muslimness.

Like Salah Hassan (2012), Mohja Kahf locates the origins of Muslim American literature in the Muslims of the Black Arts Movement (1965-75), presenting The Autobiography of Malcolm X(1965) as one of its formative texts. She offers a broad definition of the first grouping, "the Prophets of Dissent," which includes a wide array of texts from the foundational works of the Black Arts Movement to contemporary Muslim 
writing that is inspired by the BAM. Poets such as Marvin X (Fly to Allah 1969) 11, Sonia Sanchez (A Blues Bookfor Blue Black Magical Women 1974) and playwrights such as Amiri Baraka, who in A Black Mass (1966) renders the Nation of Islam's Yacoub genesis theology into drama, serve as excellent examples of the first category. The salient characteristics of "Prophets of Dissent" are their critique of mainstream American values, and their "prophetic" and "visionary" voice (164).

While the Prophets of Dissent are positioned as "outsiders" within U.S. literatures, writers of the second category "Multi-Ethnic Multitudes" are an integral part of the American literary landscape, i.e., MFA programs, the publishing industry, and literary journals. Members of the Multi-Ethnic Multitudes include Kashmiri American poet Agha Shahid Ali, an influential figure in the mainstream American poetry scene with a literary prize named after him at the University of Utah, Palestinian American poet Naomi Shihab Nye, Sam Hamod, an Arab Midwesterner who was publishing poetry in journals at the same time as Marvin X, novelist Nahid Rachlin, Mustafa Mutabaruka, Khaled Hosseini, and Michael Muhammad Knight. These writers, Kahf argues, often enjoy insider status as their texts and interviews are circulated within the literary market. The third category "New American Transcendentalists" is characterized by a mélange of broad Sufi aesthetics and forms such as Arabic, Farsi, Turkish, and Urdu and the nineteenth century American transcendentalist philosophy. Here, writers such as Daniel 
(Abd al-Hayy) Moore, a Beat poet who converted into Sufism, illustrate the salient characteristics of this grouping in his Ramadan Sonnets (City of Light 1986).

Lastly, Kahf refers to the fourth group as "New Pilgrims," devout Muslim Americans that are committed to an Islamic way of life. Muslim American writers in this category, Imam Yusuf, Samantha Sanchez, Umm Zakiyya and so forth, use religiosity and piety as a thematic anchor in their creative works. Kahf compares "New Pilgrims" to the conservative Puritans of early American history such as Ann Bradstreet and Cotton Mather. She explains that their piety "does not prevent them from being capable of producing great literature, any more than it prevented the great Puritan writers" (164). The premise of Kahf's thematic categorizations of disparate texts under the umbrella of literary Muslimness is quite clear: to create a space where Muslims harmonize as writers who mitigate their identities as Muslims and Americans. The historical analogy she draws between the first settlers and the contemporary immigrants within the context of literary Muslimness aptly challenges not only the literary canon but also the sociopolitical discourses that brand Muslims as outsiders. Literary Muslimness is also inclusive in that, unlike the category of Islamic fiction, it does not seek to place writers of Muslim heritage as well as their characters on a scale based on their level of piety12.

As Kahf concludes her article, she stresses that the majority of the texts produced by writers who identify as a Muslim can be read in other categories than Muslim writing such as African American, Arab American, Turkish American, and South Asian

12 But works of Islamic fiction are one of the subcategories of Muslim writing in this schema. 
American. "But," she adds, "something is gained in reading them together as part of an American Muslim cultural landscape" (163). What that "something" is, however, left unexamined in her essay. She writes that "There are pleasures and patterns that emerge from reading this profusion of disparate texts under the rubric of Muslim American cultural narrative." "It is time!" she states, "I hope, as this field emerges, that others will do work in areas I have left aside in this brief initial exploration" (167). Kahf's call for a comprehensive study that explores the interplay of Muslimness, literature, and diaspora is one of many. Her initiative in offering a conceptual framework for a Muslim American cultural and literary landscape that still is in a formative stage is crucial and forms a reliable basis for rethinking the intersections of literature and Muslimness in the Global North through Muslim diaspora space.

While Kahf is concerned about diaspora literature in the context of the U.S., this project contextualizes the link between Muslimness and literary practices within a transnational perspective. There is certainly merit in studying further the notion of literary Muslimness and its position within the context of American letters and cultural narratives. However, at a historical moment when Muslimness itself has been in the limelight as a global phenomenon, or rather a "problem," I suggest that a shift in focus from the American context towards a Euro-American context reveals common trends, patterns, and thematic reconfigurations in the works of literature by writers of Muslim origin, which I seek to investigate through the concept of Muslim diaspora space throughout this project. 
I introduce this new way of reading in the following four chapters. In Chapter 1, I present a discussion of the concepts "Muslimness" and "diaspora space" that are at the heart of this project. This chapter offers a theoretical exploration of "Muslim diaspora" as an analytical framework that foregrounds the dialectic of movement and dwelling, location and dislocation, and difference and sameness as a crucible for the formation of Muslim subjectivity. In this chapter, I demonstrate that Muslim diaspora space as a mode of analysis takes its impetus from, what Olivier Roy (2004) calls, "the Western Approach," that systemically reinforces Muslim identity as a monolith on both sides of the Atlantic. Although Muslim immigration to the Global North is not a recent phenomenon, I suggest that the stigmatization of Muslims and Islam in the diaspora today is unparalleled, with dire consequences for domestic and global peace. Thus, Chapter 1 shows that the starting point for Muslim diaspora space is the ways in which Muslim experiences, as well as Muslim narratives, are perpetually rendered "diasporic" and "Islamic" through "the Western approach" that views them through the lens of cultural exclusion, defamation, constant surveillance, and so forth.

Chapter 2 uses the lens of Muslim diaspora space to present a contrapuntal reading of two works of historical fiction penned by Muslim writers, The Moor's Account (2014) by Laila Lalami and The Kindness of Enemies (2015) by Leila Aboulela. This chapter is invested in studying how historically important Islamic figures-Esteban the first Muslim to arrive at the North America in the 15th century and Imam Shamil the Islamic leader of Caucasian resistance to Russia in the 19th century-are re-imagined in respectively The Moor's Account and The Kindness of Enemies. My analysis focuses on 
the curious ways in which the texts link the diasporic experiences of the revered Islamic figures into the exigencies of Muslim diaspora today. Both novels, I argue, are revolutionary within the field of Muslim narratives, for they do not situate the historical figures merely within the political context of their resistance but rather emphasize their contradictory subject positions through the intricacies of their lived experiences.

Chapter 3 explores the shifting notions of home within the framework of Muslim diaspora space through close readings of Diana Abu-Jaber's Crescent (2003), Elif Shafak's The Saint of Incipient Sanities (2004), and Randa Jarrar's A Map of Home (2007). In this chapter, I study the ways in which the novels negotiate the notions of Muslimness and western-ness through Avtar Brah's notion of "a homing desire” (1996). This negotiation, I argue, speaks to the paradoxical processes of uprootedness and migration in the transcultural context that stipulates a starting point, a sense of what it might mean to be "at home" in cross-cultural circumstances.

In Chapter 4, I use the lens of Muslim diaspora space to shift my focus to the controversial concepts of Islamic feminism and queer Muslimness. In an effort to highlight the importance of merging Muslim literary studies with feminist and queer theories in my final chapter, I offer analyses of Leila Aboulela's Minaret (2005), Shelina Janmohamed's Love in a Headscarf (2009), and Tanwi Nandini Islam's Bright Lines (2015). I suggest that these three texts break new ground by placing alternative modes of Muslim womanhood at the heart of Muslim diasporic experience.

\section{Conclusion}


Above the open call for submissions from Muslim writers published after the "Muslim ban," stands a drawing by artist Mari Andrews that expresses the urgency of the literary agents' statement. Andrews's artwork houses a strikingly enormous grey torch with vibrant bursting flames spluttering from its fire. The word, "Hope," is inscribed on the torch in capitals. The torch is surrounded by three smaller human figures which Andrews labels as respectively, "Musician," "Artist," and "Writer." The figures carry their own miniature torches in hand and ladders that would evidently allow them to reach out to the torch of hope. The artwork speaks to the ways in which hope and resistance can be cultivated in the face of cultural ostracism and the rise of global nativist movements. The pairing of the collective statement with Andrews's drawing may seem too idealistic to some but nonetheless conveys a crucial message about the role of the artist and what cultural and literary representations can offer in the ongoing debates about the so-called "problem" of Muslims in the Anglophone North Atlantic. 
Chapter 1: Towards a New Mode of Reading Muslim Diasporic Writing: Muslim Diaspora Space as a Literary Site

The circulated images of Muslims in mass media reflect the ways in which Muslims have, yet again since 9/11, come under the critical gaze of Euro-America13 with renewed force since the global rise of nativist movements in the U.S. and Europe. Two main modes of thinking pervade the current discourse on Muslimness. The first is characterized by Eurocentric discourse and its propensity to define "the secular" in contradistinction to Islam. The secular is reimagined as the opposite of Islam, masking "the religious shape and content of Western public life and its imperial designs" (Brown 10). The second is the Islamist discourse that propagates a prescriptive and restrictive mode of Islam, perpetuating the dichotomy between a good Muslim and a bad Muslim, a devout and a secular Muslim. Despite the differences in their motivations and objectives, both lines of thinking foreground Muslimness as a singular entity and fundamentalism as its essential condition.

The "question" of Islam as a theological corpus dominates the polarizing debates on Muslim identity, lending itself to a paradoxical invisibility of the diverse voices of Muslims. Despite endless debates and discussions on Islam and Muslims in media and academic circles, alternative ways of being a Muslim and the processes by which Muslims make meaning of their subjectivity are perpetually rendered invisible. A discussion on representations of Muslims in the hegemonic discourse thus necessitates 
exploring a seemingly simple question: What exactly is "Muslimness"? Or in Olivier Roy's words (2004):

Whom do we call a Muslim? A mosque-goer, the child of Muslim parents, somebody with a specific ethnic background (an Arab, a Pakistani) or who shares with another a specific culture? What is Islam? A set of beliefs based on a revealed book, a culture linked to a historical civilization? A set of norms and values that can be adapted to different cultures? An inherited legacy based on a common heritage? (21)

In other words, if we shift our focus to the diversity of Islam(s) and Muslims, who is then considered a Muslim? How is Muslimness defined by western ideology? How do Muslim individuals define it? In the light of this study's concern about Muslim diasporic subjectivity, this chapter seeks to clarify the terms and concepts that I use throughout this project to lay the groundwork for a far deeper understanding of Muslim diasporic cultural production in general and Muslim writing in particular. I offer an exploration of the terms "Muslimness" and "diaspora space" to suggest that the intersections of cultural studies and literary analysis can provide us with a conceptual tool that highlights the paradoxical nature of Muslimness rather than Muslimness as a mere theologized vision. Although "Muslimness" is used in popular culture simply to refer to the qualities and markers that to a certain extent make us look Muslim, the complexities of the term must be unpacked to better comprehend its shifting meanings within the framework of Muslim diaspora space as I will explore throughout this chapter. 


\section{Muslimness and Its Discontents}

The few studies that offer a theoretical reflection on the meanings of

Muslimness 14 emphasize the socially constructed nature of the term. Muslimness as a preconceived notion is often linked to traditional Islamic values, thereby suggesting homogeneity across Muslim countries whose lived experiences of Islam may greatly vary. This widely circulated definition of Muslimness reinforces the essentializing tropes through which Muslim identity has been constructed. The implications of the definition of the term cut two ways. First, Muslimness and religiosity are conflated in a way that aligns with the traditional Islamic school of thought that casts Muslimness as purely theological. In "Policing Gender, Sexuality and Muslimness" (2012), Anissa Helie discusses the ineluctable consequences of this approach that deems "alternative visions of what it may mean to be a Muslim [...] as culturally irrelevant; they may even be denounced as blasphemous" (4). The rigid conflation of Muslimness and traditional Islamic principles may lead to the labelling of non-practicing Muslims as "not Muslim enough." Second, Muslimness is reduced to a single entity that evokes a sense of threat and terror, corroborating the representation of Muslims "as unified and [of] Islam as monolithic in order to establish a set of totalizing "truths"" (Helie 4) about Muslims in the wider society. Both perceptions of Muslimness run the risk of endorsing a narrative that wraps Muslim identity in a single ideological cloak, reducing the multiple subjectivities of Muslims to a monolith. The polarizing rhetoric that characterizes the discourse on Muslimness constructs all Muslims as intrinsically radical and/or Islamist. Although the 
majority of Muslims in the Global North are western citizens and, as Tariq Ramadan (2013) famously argues, Islam is an irrefutable part of western identity (14), the question of integration as a security measure underpins the public discourse on Muslimness.

In the current political climate, the overwhelming amount of interest in Muslim populations seldom lends itself to an investigation of the complex, multifaceted nature of Muslimness. Instead, such impactful events as The Satanic Verses controversy, 9/11, 7/7 in London, 14/3 in Madrid and 2015 Paris attacks have shaped the terrain of Muslimness, establishing the prevailing narrative that positions all terrorists as Muslims and even at times all Muslims as terrorists. In "Lost in Translation: Writing Back from the Margins" (2008), Jasmin Zine writes that these incidents have played a pivotal role in justifying "draconian state security policies, racial profiling and closed borders"- the processes that "make being 'Muslim by name only' impossible." "All Muslims," she notes, "face being 'guilty by association' with a Muslim name" (112). Muslims are often labeled as "unenlightened outsiders who, while they may live in the West, still have an allegiance to values different from those recognized in Europe and North America" (Morey \& Yaqin 1).

This inflammatory rhetoric of othering, or what Stuart Hall (1997) calls "repertoires of representation" (225), speaks to the paradoxical ways in which Muslims, unlike other citizens of the Global North, "have been called upon to prove their citizenship and commitment to the secular nation state" (Chambers and Herbert 2015;2). Although the complexity of the term Muslim is not completely lost on policy makers (i.e. Runnymede Trust 1997 and the U.S. Congressional Research Service 2005), as Haideh 
Moghissi, Saeed Rahnema, and Mark J. Goodman (2009) demonstrate Muslims "are the only diaspora population in which character, behavior, attitudes, inclinations, and normative conduct still continue to be defined by religion alone" (85). They underline the key role that religion plays for other immigrant populations "whether they be Argentine or Russian Jews in Tel Aviv, or Salvadorian, Puerto Rican, or Haitian Catholics who have recently made their way to Latino communities in Queens, Brooklyn, or the Bronx" and argue how "it is understood that religion in these communities plays one role among many, and it does not draw as much attention on the part of social commentators" (85). The overemphasis on religiosity when Muslims are under discussion assumes that secularism and irreligiosity can be used interchangeably, resulting in a discourse that disregards the existence of a large number of Muslims who identify as both secular and religious, practicing and secular, or non-practicing. The stereotypical image of the Muslim figure as fundamentally radical is implicated in, as Morey and Yaqin (2011) discuss, "an agenda that simultaneously announces its desire to 'engage' with them [Muslims] while at the same time forcing debate into such contorted and tenuous channels as to make a meaningful flow of cross-cultural discussion almost impossible" (2). The discursive focus on radical Islamists, who make up a small percentage of diasporic populations, particularly in media representations further obfuscates that diasporic Muslim communities, like other communities, are comprised of atheists, skeptics, secular individuals, practicing members, as well as orthodox believers. For instance, Moghissi, Rahnema, and Goodman (2009) emphasize that there are around seventy-two sects within Islam itself, "each considering itself the 'saved sect' and 
the others as misguided. Apart from the major division between the majority, Sunnis and the minority Shi'as, there are major subsects and divisions within each sect" (8). The heterogeneity of Muslim communities undoubtedly reflects the complex history of the Middle East and Islam, which is rarely addressed in discussions on Muslimness. Given the diversity of Muslim populations, the question here is: How can a Michigan Lebanese, a Nuremberg Turk, a London Pakistani, a California Iraqi or a French Algerian possibly share a singular identity? It is highly problematic to state that they do. However, prevalent social categories of Muslims in the U.S. and Europe reify the essentializing process where cultural, sectarian, and political discrepancies fall between the cracks. According to Naser Meer and Tariq Modood (2009), this process is instantiated by the conflation of the age-old Orientalist discourse and, what he calls, "cultural racism." The racialization of religion, in this context Islam, can be viewed as an intriguing convergence of cultural and genetic determinisms; ideals of culture and religion are considered to be reproduced irrespective of time, space, lived experiences, local and global influences.

Kundnani (2014), too, writes that "since all racisms are socially and politically constructed rather than reliant on the reality of any biological race, it is perfectly possible for cultural markers associated with Muslimness (forms of dress, rituals, languages, etc.) to be turned into racial signifiers" (11). Similarly, in Making the British Muslim (2014) Nicole Falkenhayner discusses the ways in which the term "Muslim" has become deeply linked with color in Britain since the turn of the century. "To give somewhat a drastic example from a historical perspective on English thug violence," she explains, "whether 
you wanted to bring to bear physical violence to Blacks in the 1970s, to Pakis in the 1980s or to Muslims in the 2000 s - the victims could potentially have been the same individuals in every case" (11). She then aptly remembers writer Hanif Kureishi's famous interview with Independent in 2009, where "he recounts how one of his sons touched his skin and asked him: 'Am I a Muslim?' (14). This shift to a common perception of Muslimness as a quasi-ethnic marker of difference is crucial, for the racialization of culture and faith is at the center of the Islamophobic discourse that dates back to the Iranian Revolution (1979) and The Satanic Verses controversy of the late 1980s, the two historical incidents that had already raised questions about the politics of Muslim subjectivity in the pre-9/11 context.

The Satanic Verses controversy is perceived as the historical moment in which Muslim identities were first constructed as political. Modood (2010) defines "the Rushdie Affair" as "a crisis that led many to think of themselves for the first time as Muslims in a public way" (2). Although the novel had received positive reviews on western platforms right after its publication, its ban in India in October 1988 altered its reception. Through the Islamic opposition's agenda, the government of Rajiv Gandhi banned the book on account of "a direct attack on Islam" (qtd. In Falkenhayner 26) against which Rushdie defended his right to freedom of expression. The controversy in India had rapidly become widespread in the Indian, Pakistani, and Bangladeshi communities in Britain, prompting for the first time their collective organization. The intellectual meaning of the passages quoted and circulated in the circle of Muslim organizations may have provoked the protestors; however, it was the ways in which Muslims often felt insulted and 
disrespected by Euro-centric culture that fueled the protests 15 . The tension rapidly escalated with the Iranian leader Ayatollah's fatwa and the Bradford book burning in 1989 that brought into focus the polarizations between the British national public/its western liberal values and the British Muslim minority/its Islamic values. Mass media's reactions to the "emerging" Muslim minorities, according to Falkenhayner, mark the historical specificity of The Satanic Verses controversy, which is "precisely that the clustering of images of Islam/Islamism/terrorism concerning not only public knowledge of majority Muslim countries but, more importantly the perception of Muslim migrant communities within the West was evolving in these years" (34). In other words, the controversy quickly became a symbol of the east against west paradigm, unmasking the supposed backwardness of Islam and its incompatibility with western liberal values.

In his discussion of The Satanic Verses, Edward Said emphasizes the novel's "instant historicity and ongoing significance," viewing the controversy as "reflecting the history of the modern relationship between Islam and the West" (qtd. In Falkenhayner 35). Following Said, writer Aamar Hussein, too, retrospectively stresses the historicity of the controversy, stating that it was "the first event that made me identify as Muslim rather than South Asian." "Until then," he continues, "we were all in it together, and we didn't make overt differentiations between, or amongst ourselves. After the Affair, a whole rhetoric of Otherness emerged around The Satanic Verses" (77). Media narratives and representations of Muslims during the controversy marked the beginning of anti-Muslim sentiments in the Global North. It was not until 9/11, however, that the frequency of

${ }^{15}$ As Falkenhayner (2011), Modood (2010), and Santesso (2011) have studied in detail. 
Islamophobic incidents increased drastically. As novelist Nadeem Aslam states, The Satanic Verses controversy made people "aware that something was going on, but it wasn't a pressing concern to mainstream society until 9/11 (qtd. In Chambers 2011; 145). Drawing on Modood's argument on the politics of being Muslim, Moghissi, Rahnema, and Goodman (2009) discuss the increasingly discriminatory nature of perceptions about Muslims since The Satanic Verses controversy:

So entrenched are perceptions about Muslim cultural values, religious institutions, and traditional mindsets that it is assumed they are shared by all members of the various communities; this gives these institutions a quasi-natural or biological character that is taken to be inherited, automatically reproduced, and unchangeable. (151)

Despite the wide range of beliefs, traditions, and cultures that constitute diasporic Muslim groups, Muslims are still increasingly marginalized as fundamentally incompatible with the values of their societies. The War on Terror and the Islamophobic rhetoric of conservative right-wing parties in the Global North have since worked to further otherize Muslim populations and to designate them as "the problem" that complicates the process of integration.

Olivier Roy in Globalized Islam (2004) aptly refers to the hostile attitude and rhetoric towards Muslim populations as "the Western approach." Acknowledging the contextual distinctions between Europe and the U.S., he highlights in Europe "a conjunction between Islam, colonial history, a territorial frontier with the south, 
immigration, and the contemporary spaces of social exclusion" that shapes the representation of Muslims, which was not the pattern in the U.S. He explains:

The debate on Muslim public religious expression is rather different [in the U.S. and Europe]. European-Christian churchgoers share the same reluctance as secularists toward the inscription of Muslim religious practices in the public sphere $[\ldots]$ while in the U.S. the debate is not about public expression of religiosity but about sharing common values, in religious and ethical terms. (17) Although Roy does not discuss the varying immigration patterns, immigration in Europe has been characterized by the guest-worker programs, which brought in temporary workers who eventually settled down in the host society. Unlike the U.S., immigration has not been constructed as the core of the nation in Europe. Despite such major historical and political discrepancies, however, as Roy adds "the same clichés regarding Islam have been at work in the intellectual debate on both sides of the Atlantic," and that "in the sociological composition of the Muslim population in those regions, now we can speak of a common Western approach to Islam" (17). Of course, Roy was writing in 2004, and "the Western approach" to Muslim groups since then has increasingly been marked by anti-Muslim policies, as well as by a rehash of the age-old controversies over the construction of minarets and mosques ,and the hypervisibility of hijabs and burkas. Although Muslims, Arabs, Middle Easterners, and others who bear physical resemblance to the members of these groups have already been wary of potential hostility from the larger society since $9 / 1116$, the common western approach used by state leaders to 
"control" and "contain" Muslim populations has assumed new dimensions recently under the current administration in the U.S. — which has brought into focus a global rise in neonationalism, the revival of the xenophobic rhetoric in the name of nationalism.

Following the U.S. executive order on the select Muslim-majority countries and the British Referendum on Brexit, the right-wing "Europe of Nations and Freedom" coalition organized an official meeting in Prague in 2017 to discuss the creation of a united Europe without the European Union. The gathering was attended by far-right members of the European Parliament, including Marine Le Pen of France, Geert Wilders of the Netherlands, and Tomio Okamura, leader of Czech far-right "Freedom and Direct Democracy" party. Wilders, the leader of the Netherlands' Freedom party (PVV), called for a "Donald Trump-style" travel ban in Europe to resolve the issue of "Islamization." He urged European nations to "adopt a totally new strategy" and to "have the courage to restrict legal immigration instead of expanding it, even if we sometimes have to build a wall." Following Wilders, Janice Atkinson, the independent British MEP, emphasized the pressing need for "a Czexit referendum," encouraging the Czech Republic to follow Britain's exit out of the European Union. Invoking conservative sentiments of the Thatcherist era, Atkinson stated that "Europe is stronger precisely because France is France, Spain is Spain, Britain is Britain and, just as important, Czech is Czech.” She added, "Long live the Europe of nations. Long live the Czech Republic" (Heijmans and Goeij 2017).

In another rally in Germany where the leaders of the conservative right gathered, Le Pen declared: "In 2016, the Anglo-Saxon world woke up. In 2017, I am sure that it 
will be the year of the Continental peoples rising up." Right before the rally, she had wasted no time seizing on the fatal shooting of a police officer on the Champs-Élysées, claimed by ISIS, and transformed the French elections into a referendum on, what she called, "radical Islam." Geert Wilders, whose anti-Muslim party led the polls for spring elections in the Netherlands, added that "The world is changing. America is changing. Europe is changing. It started last year with Brexit, yesterday there was Trump and today the freedom-loving parties gathered in Koblenz making a stand" (Smale 2017). To be sure, these disturbing flare-ups in xenophobia target all immigrant and refugee populations. It is, however, evident that the anti-Muslim rhetoric remains at the heart of the conservative political agenda.

The "threat" that Muslims perpetually pose to the French nation, the English nation, the German nation, the Italian nation, and so forth, echoes throughout the continent. Donald Trump's campaign motto, "Make America Great Again," with its implications of "greatness" in morphing the society into one that is predominantly white and Christian, for instance, reverberates in the Catholic Northern League's Islamophobic rhetoric in Italy ("Europe must be Christian again") as well as in the Polish PM Mateusz Mowawiecki's recent call to "Make Europe Christian again" (Bartyzel and Strzelecki 2017). Similarly, the reaction to the Syrian refugee flow in the majority of European countries mirrors initiatives immediately taken by the new U.S. administration, increasing the security regulations that were already strict for visitors arriving from Muslim countries. More alarming is that these overtly Islamophobic attitudes and policies 
are continually used as justifications for social, economic, symbolic, and physical violence against migrants and citizens of Muslim heritage.

In Sweden, despite the implementation of the Law against Ethnic Discrimination in 1994, Muslims as immigrants and refugees per definition still live in ghettoized suburbs — as Anne Sofie Roald and other scholars suggest — not because Muslims refuse to integrate; rather, it is the Swedish social structure that does not allow them to do so (qtd. In Moghissi, Rahnema, and Goodman 150). Early in 2017, a citizens' initiative was launched in Finland to amend a bill that would outlaw wearing a headscarf in public. Terhi Kiemunki, a former member of the Finns Party, who was convicted of incitement to hatred was among the initiators. Jukka Ketonen, current chairman of the Finnish Defense League (FDL), too, who claims to be battling 'Islamic extremism,' helped launch the program (Bayrakli and Hafez 2017; 20). In the U.K., Tell MAMA (Measuring AntiMuslim Attacks), a non-profit organization that monitors anti-Muslim hostility, has called attention to the growing tide of Islamophobia in its latest review report. In 2017, Tell MAMA revealed the highest number of anti-Muslim incidents across the U.K — with 1,201 verified incidents of anti-Muslim hatred. 70 percent of these incidents occurred offline, face-to-face, representing a 30 percent rise in offline reports; the verified online reports demonstrate a 13.6 percent increase (4-5). Tell MAMA's 2018 report confirms the increase in anti-Muslim incidents online and offline17. Furthermore, the 2017 and 2018 European Islamophobia Reports (EIR), prepared by forty researchers from thirtycolumn referring to veiled Muslim women as 'letterboxes' and 'bank-robbers' [...] anti-Muslim incidents increased by $375 \%$ - from 8 incidents the previous week, to 38 in the following" (Tell MAMA 2019). 
three European countries, reveal a drastic increase in hostility against Muslim populations around the continent.

The EIR demonstrates that Plataforma Ciudadana contra la Islamofobia reported around 546 hate crimes committed against Muslims in Spain. According to the DITIB (The Turkish-Islamic Union for Religious Affairs), in Germany there were 101 attacks on mosques throughout 2017. The official government records further indicated that nearly 908 hate crimes were committed against German Muslims in the same year, ranging from verbal to physical attacks and murder attempts. In Sweden, three members of the national socialist Nordic Resistance Movement were convicted of bombing of two refugee housings. In London, a man drove his van deliberately into a crowd of Muslim worshippers leaving the north London Finsbury Park Mosque. In Poland, a Pakistani Muslim man was severely beaten by a group of men in Ozorków (23). By the numbers, the increasing Islamophobia looks like a trend across the Atlantic too.

The Council on American-Islamic Relations (CAIR), a Muslim civil rights and advocacy organization, reported a 17 percent rise in anti-Muslim incidents across the U.S. in 2017. This was accompanied by a 15 percent increase in hate crimes targeting Muslim-Americans. Moreover, CAIR's quarterly 2018 report shows an 83 percent and a 21 percent increase in, respectively, anti-Muslim bias and hate crimes - as compared to the first quarter of 2018. The FBI and U.S. Customs and Border Protection, too, have reported a 60 percent increase in anti-Muslim incidents. The list is long, and the current surveys solely reflect the incidents that were officially reported. These numbers point out to the tip of the iceberg - revealing that even though Muslim immigration to the U.S. and 
Europe is not a recent phenomenon, the stigmatization of diasporic Muslims today is unparalleled, with dire consequences for domestic and global peace. The recent mass shooting at two mosques during Friday prayers in Christchurch, New Zealand in March 2019 certainly attests to the urgency of addressing the proliferation of Islamophobia across continents18. As the reports demonstrate, the legitimacy of Muslims' status as citizens and migrants, as well as their safety are alarmingly contingent on the sociopolitical climate.

Despite the drastic increase in anti-Muslim violence in the U.S. and Europe, the sociopolitical discourse has yet to shift to constructive discussions that highlight the diverse voices of Muslims. Conversely, Muslim identity continues to be homogenized as fundamentally orthodox and threatening. The perpetuation of flattened, reductive notions of the Muslim figure overlooks the large number of non-practicing and/or practicing secular individuals of Muslim cultural background who are often directly influenced by the Islamophobic rhetoric. Moghissi, Rahnema, and Goodman (2009) point out to the double alienation of the vast majority of Muslims who, "identified on the basis of cultural heritage, are recognized neither by devout Muslims nor by average citizens or mainstream media in the West” (9). In an interview, writer Kamila Shamsie poignantly reflects on the positionality of Muslims as sociopolitical objects rather than agents in the discourse on Muslimness. "It is hard to be a Muslim in a post-9/11 world," she states, "and not be aware of 'Muslimness." She explains that current debates on "the Muslim 
problem" tend to construct a monolithic Muslim identity, compelling Muslims to perform a certain type of Muslimness:

You get asked: are you a Muslim? Yes! And you hear all kinds of things being said about Muslims. And you start to feel yourself being Muslim in a way you never felt before. People will say: So what is it about Islam that makes people turn to violence? And so, on the one hand, there is the assumption that this religion is deranged and on the other, there is the assumption that you must speak up for it. Both of these situations are uncomfortable. (Kramatschek 2009)

Shamsie argues that a very particular ontology of Muslimness is inscribed onto Muslim subjectivity, centering the perception of Muslims as opposed to the multiple ways in which Muslims make meaning of their subjectivities. Shamsie's commentary speaks to the pressure that is placed on Muslims to perform a type of Muslimness that affirms their loyalty to the larger society. In an attempt to fight against Islamophobia, for instance, most Muslims feel compelled to denounce and apologize for several violent acts committed in the name of Islam around the globe. They are expected to explain and defend the peaceful philosophy of Islam and its ancient feminist ontology to correct the anti-Muslim rhetoric.

In the same vein, writer and journalist Haroon Moghul interrogates the social, political and historical baggage behind a Muslim identity in his memoir How to Be a Muslim (2017). Like the majority of Muslims living in the U.S. and Europe, Mogul straddles two seemingly different paradigms, Muslim and western, which are positioned in contradistinction to one another. In an interview, he discusses the ways in which his 
identity as a Muslim bears indelibly those marks that have been perpetually used to otherize Muslims:

Every time something bad happens you're called upon to apologize, to explain. It means that your entire identity is pegged to events in other parts of the world usually and almost exclusively negative events — and your entire religious life becomes the articulation of why your community is not a problem or should not be perceived as a problem to wider America. (Gross 2017)

Both Moghul and Shamsie point out to the construction of Muslimness in a fixed ontology regulated by the anti-Muslim discourse. What is unsettling here is that the type of Muslimness that Muslims are asked to portray through their solicited apologies and explanations instantiate and affirm the assumptions that underlie the Islamophobic rhetoric. Such narratives of clarification, elucidation, or justification focalize the questions and concerns posited by the biased group, decentering Muslim agency. If Muslim migrants and citizens do not present an "acceptable" Muslimness—often referred to as "moderate" Muslimness that somehow suggests "active assimilation into mainstream culture," as Morey and Yaqin (2011) claim, "they can find themselves threatened with the potential loss of their legal right" as American or European citizens (68). This predicament, what Moghul aptly calls, "being a professional Muslim," as opposed to Muslimness as a lived experience is, of course, one with which most diaspora writers of Muslim heritage grapple.

Within a milieu where Muslim individuals are anticipated to carry the burden of representation, writing is seldom an act of creating a mere story. In her essay "Writing 
Muslims” (2011), Laila Lalami discusses the pressure placed on writers of Muslim heritage to portray a unified, religious Muslim identity. "To write about European Muslims, to write for European Muslims, to write as a European Muslim is to write in a state of invisibility," she notes, "which whether wished for by right-wingers or piously denounced by left-wingers, is nonetheless stubbornly real" (145). Lalami's emphasis on the paradoxical invisibility of Muslim writers, often challenging to negotiate, speaks to the complexities of the matrix against which one's Muslimness is measured. Signifiers such as the burka, the hijab, beard, and skullcap are overt markers of Muslimness that indicate strong tries to Islamic tradition. Then, other subtler markers- one's name and country of heritage — are sometimes associated with Muslim identity. Yet still other measurements such as socioeconomic status, gender, and class, too, dictate whether a Muslim can be identified and/or profiled (or not). In her article, "I'm Not Your Muslim," wittily titled in reference to Baldwin's "I'm Not Your Negro," Nesrine Malik calls this prevalent system of measurement, "the Identity Matrix," and "The Privilege Scale."

"In order to predict how likely it is that a Muslim will be discriminated against," Malik writes, "jobs, wealth, education and other markers of status interplay with the degree of perceived Muslimness that can confer or deny immunity." She then adds: "This is pretty much how identifiers are leavened with social status (or lack thereof) across minority groups in most parts of the world" (2017). The complexity and simplicity of the process of stereotyping (as well as of profiling) Muslims is important to note - though it is beyond the scope of this project. But the overwhelming prevalence of "the sliding scale" system within the publishing industry should not be overlooked. Writers who can 
be "categorized" as Muslims are often asked to "come out" and render their Muslimness — as already defined by the dominant discourse — visible within the cultural domain where unlike "whiteness," Muslimness is often capitalized on. The demands of the literary marketplace for Muslim writers tend to limit their artistic engagement, requiring them to prioritize their trials and tribulations as outsiders and/or native informants.

For instance, Lalami (2011) discusses that her readers often ask her to "reflect more specifically on the place of Islam in [her] writing process." "This is an interesting turn of phrase," she suggests, "one that seems to presuppose that, before I begin writing every morning, I consult my copy of the Qur'an. At the risk of disappointing some people, I do not. And I doubt if any Muslim novelist does" (146). Lalami's response points out to the ghettoization of postcolonial and diasporic writers as Rosemary Marangoly George studies in The Politics of Home (1999). George shows that diasporic writers are often formed into particular clusters in which they are anticipated to emphasize political issues at the expense of formal concerns in literary texts. Ghettoization of diasporic Muslim writers in this context arises as a direct result of the divide between aesthetic and politics deriving, as Král (2009) argues, "from a failure to see that aesthetics is never about aesthetics alone but also about politics and the inclusion and exclusion of postcolonial [diasporic and transnational] writers into the canon" (21). It is against the backdrop of such demands and social tragedies that writers and artists of Muslim origin in the Global North are creating a resistant diasporic discourse, which, I argue, can be highlighted through the lens of Muslim diaspora space. 
As I will demonstrate in the following chapters, this creative collectivity does not differ greatly from the emerging social trends and patterns within Muslim communities across North America and Europe. As Moghissi (2006) argues, "Muslim individuals and communities do not necessarily mobilize around a Muslim identity based on historical commonalities founded in the values, religious affiliations and languages of heritageating countries." The sense of connection and solidarity that emerges in the diaspora today is rather a consequence of "the urgent contemporary and common concerns and grievances that these diasporic communities experience in relation to the receiving societies" (x). It is precisely this shift in the patterns of diasporization from articulations of a common ethnicity and homeland to a heightened Muslimness that is contradictory, paradoxical, and diverse that explicates the contours of Muslim diaspora space. In this light, from a social science perspective, the concept of Muslim diaspora space can be used to study social formations in diasporas; however, this project is concerned with Muslim diaspora space as a mode of reading that challenges the mainstream Eurocentric expectations of Muslimness. Muslim diaspora space as a conceptual tool can shift the overemphasis from Muslimness as a religious ideology to Muslimness as a process of meaning-making. Although my focus in this project is on Muslim literary production, Muslim diaspora space as a concept, which is slightly different from "Muslim diaspora," can be better understood through the theoretical discussions on "diaspora space" and "spaces in between difference." 


\section{Towards Muslim Diaspora Space: A Theoretical Look}

Diasporas are, without a doubt, heterogeneous and contested spaces. The diasporization of various groups is contingent on the specific economic, political, and social structures that they encounter in the host society. In her discussion of South Asian diasporas in Britain, Pnina Werbner (2004) addresses the complexity of modern diasporas. Unlike the archetypal Jewish, Armenian and Greek diasporas that share a territorial origin and a unique history, regional diasporas like South Asian, Middle Eastern, and Latin American, she argues, should be examined as "segmented" diasporas whose members "may unite together in some contexts and oppose each other in other contexts." Werbner highlights a shared sense of "a rich material culture of consumption" and "a dominant religion (e.g. Islam, Catholicism)" amongst the members of regional diasporas that can "create public arenas and economic channels for cooperation and communal enjoyment, which cut across the national origins or religious beliefs of performers and participants" (900). Despite possible internal conflicts, a sense of belonging to a shared culture can transgress polarizing national, ethnic, and sectarian clashes in the diaspora. This does not counter the fact that "diaspora" invokes a notion of locus, a homeland from which one is dispersed. It does, however, emphasize the coexistence of "here" and "there" and its articulation with an anti-teleological temporality, as James Clifford (1994) famously suggests. In diaspora, “a shared, ongoing history of displacement, suffering, adaptation, or resistance" as well as culture is as important as "the projection of a specific origin" (306). Following Clifford, Avtar Brah (1996) discusses the politics of locality and the pivotal role that economic, political, 
sociocultural processes, bureaucracies, and state policies play in how a group comes to be positioned in the diaspora.

Brah interrogates the question of relational positioning through the concept of diaspora space, which, as opposed to "diaspora," acknowledges "the configurations of power that differentiate diasporas internally as well as situates them in relation to one another." The starting point for diaspora space is not only the historical experience of displacement, but also "the entanglement, the intertwining of the genealogies of dispersion with those of "staying put'" (209). Diaspora space unsettles the established notion of a neutral public sphere as it is the point of convergence in which "arrival" and "departure" are equally significant forces for the formation of diasporic subjectivity. Diaspora space then is not only inhabited by those who "arrive" but also by those who have already "settled down." Brah's point is this: inhabited by immigrants, refugees, and international students, as well as by long-settled populations, diaspora space unmasks the complex processes of cultural formation and the intersectionality among various diasporic groups. In other words, all who inhabit a diaspora space are deeply transformed by the encounter- albeit on different levels depending on the various configurations of power mobilized by this contact. Diaspora space as a particular form of migration can be illuminating in understanding the shifting notions of Muslimness.

If we perceive "the Global North" as a diaspora space where Muslim Middle Eastern/South Asian/North African segmented diasporas intersect among themselves, along with the entity "hegemonic western-ness," these complex encounters re-inscribe the constructed notion of Muslimness and western-ness in the process. It may seem 
counterintuitive to discuss the corporeality of a diaspora space that is specifically and collectively Muslim — due to the heterogeneity of Muslim groups in the Global North. Yet it is precisely the representation of Muslims as an inherently singular religious group that activates the cultivation of a collective consciousness in the context of Muslim diaspora space. The production and reproduction of the clichés about Muslims, as Moghissi, Rahnema, and Goodman (2009) suggest, "has turned an imagined attribute into a social reality." Moreover, Muslim diaspora space fosters a deeper connection that brings Muslims in the Global North together not only in "in various averts of protest" but also "in an expressive sense of connection and solidarity" (11) — and more importantly for my purposes in oppositional re-narrations of Muslimness in creative texts.

It is important to remember here that even ethnic and national kinship within various diasporic groups is maintained through a mere acknowledgement of connection to the peoples whom the members have not and, most likely, will never meet. Muslim diaspora space is imagined in a similar way the members of a nation imagine and maintain a sense of belonging to their national community in Benedict Anderson's (1991) terms. Those inhabit Muslim diaspora space, like "the members of even the smallest nation," perhaps will never receive the opportunity to "know...meet...or even hear of other members," but nevertheless, "in the minds of each lives the image of their communion." As Anderson famously suggests, the question of fallacy, whether a community qualifies as one or not, is not relevant in terms of distinguishing communities. Rather, communities are recognized through "the style in which they are imagined" (6). This imaginary space, "a substance that is relatively immune to the workings of time 
through memory," Caren Kaplan (1996) argues "is not completely fictional and fantasized because it is anchored on reality" (147). "Reality" in the context of the Muslim diaspora, however, is muddled and mediated by Eurocentric discourse. The diverse communities of Muslim heritage can be established as a diasporic group not necessarily because the community itself conforms to the traditional features of diaspora such as cultural nostalgia and yearning for the homeland. Rather, as Moghissi, Rahnema, and Goodman (2009) note:

the formation of a collective identity and solidarity in the diaspora more often manifests a response to political frustration and blossoming of deep-seated resentment to the continuing colonial and neocolonial aggression against Muslim societies, accentuated an inhospitable climate in the new country. (14)

A collective consciousness develops in this space, not as a reflection of yearning for a homeland, but as a reaction to the current sociopolitical realities that profoundly affect their lived experiences. Muslim diaspora space then points specifically to, what Susan Friedman theorizes as, "the spaces in between difference" (1998) that emphasizes overlaps and commonalities, the merging as well as clashing that occur in the contact zones.

Like Brah, Friedman emphasizes contradiction as a crucible to the formation of subjectivity and the phenomenological experience of identity. In this light, Muslim diaspora space as a lens draws attention to the Muslims who are positioned within these spaces in between difference through their collective effort to resist absolutes-identity, culture, religion, and tradition as pure entities — despite their ethnic, linguistic and racial 
differences. The point of encounter between various types of Muslim identities and the hegemonic discourse may engender a sense of unsettling ambiguity, loss, and bifurcated belonging. These sentiments, however, cannot be imagined with no reference to a dialogic engagement in cultural translation. That is to say, as opposed to the dichotomies between home and the host society and between Islam and the west that permeates the discourse on "Muslim diaspora," Muslim diaspora space highlights Muslim diasporic experience as mediated by stability and instability, movement and suitedness, location and dislocation, and more importantly Muslimness and western-ness — both of which are re-inscribed in the spaces in between difference. This understanding of a fluid relational Muslim subjectivity helps to dissolve the fixity that undergirds Muslim identity as the ultimate other in the Manichean sense (Said 1978). It is in this space of dynamic encounter where negotiation of "contradictory and antagonistic instances" in Homi Bhabha's terms (1994) between different ethno-nationalities, languages and levels of religiosity lends itself to a Muslim collectivity in the face of new sociopolitical realities. Muslimness in diaspora space in this context emerges not as a marker of ethnic difference but as a fluctuating narrative of formation, moving across time and space, developing, evolving, and changing.

In this context, returning to Laila Lalami's argument on the invisibility of Muslim writers proves to be illuminating. Lalami discusses the paradox that characterizes the invisibility of Muslimness: "It may seem odd that I am speaking of invisibility in an age when one cannot turn on the radio or the television, or pick up a newspaper, or go online without hearing some sort of news about Islam.” Lalami underscores the repercussions of 
the overwhelming amount of attention Islam as a religion receives in western media. To Lalami, Islam is often omnipresent in three specific variations: oppression, violence, and poverty. She explains further:

How did I go from omnipresence to invisibility? Because the news is always about Islam, not about Muslims. ... The word "Islam" can be used to describe the Abrahamic religion, with its holy text, its rituals, its laws, and its dogma; the geographical region that extends from Morocco to the East and Indonesia to the West; the historical civilization that began in the 7th century AD; and the many individual cultures, cultures as widely different as Azerbaijan and the suburbs of Rotterdam, as clearly distinct as the Sudan and the Maldives...One hears about Islam and the West, Islam and democracy, Islam and human rights — in the same way one used to hear about communism and the West, communism and democracy, communism and human rights. Muslims, however, in their large and incredibly diverse numbers, cannot be simplified. So, while Islam may be omnipresent in Europe, Muslims in Europe are, in my view, invisible. (145) Lalami's call for a shift in focus from Islam to Muslimness draws on the nuanced ways in which scholars 19 have demonstrated that conflating Muslimness and Islamic theological tradition empties the notion of Muslimness of its ontological depth. Roy (2004), for instance, draws attention to the debate on Muslims which centers on a single question: What is Islam?:

${ }^{19}$ See Kahf (2010), Hassan (2012), and Ahmed (2015). 
Most events involving Muslims are related to Islam as such: what does Islam say about jihad, suicide bombers, violence, Judaism, Christianity, democracy, secularisation, and so on? Islam is seen as a discrete entity, a coherent and closed set of beliefs, values and anthropological patterns embodied in a common society, history and territory, which allows us to use the term as an explanatory concept for almost everything involving Muslims. (9)

Like Roy (2004), others stress the overlooked distinction between Islam as religion, encompassing the Quran, the Sunnah, fatwas, etc., and Muslim culture including art, literature, history and cuisine. The current debate on Muslims privileges the complex Islamic theological order, which occludes the broad spectrum of expressions, lifestyles and beliefs of Muslims. As Shahab Ahmed (2015) contends, the monolithic perception of Islam as a religious doctrine leads us to “...ineluctably enter[ing] into a conceptual order(ing) — into a taxonomy of ideas, actions, and objects - that assumes the universality of the Modern Western religious-secular binary" (197). In other words, the mainstream understanding of Islam conflates the secular- concerned with aesthetics, cultural elements, pleasure, and arts - and the religious whose interests lie in the prescriptive and restrictive domain.

The binary of secular vs. sacred in this context axiomatically lends itself to the normative definition of Islam in which the two paradigms are perpetually locked in tension. Ahmed explains that when "religion," rather than "truth or meaning" is the primary lens (193) through which we understand Muslimness, we tend to overlook "central ways in which Muslims have conceptualized being Muslim" (201). Ahmed 
presents a mode of Islam(s) where philosophical, cultural, and communal trajectories of Muslimness - typically relegated to the periphery — are conceived as important as the prescriptive and restrictive discourses, i.e., the law and classical texts. His theorization comprises the larger system and context of Islamic thought as well as the individual human agent (259), bringing the importance of explorative and creative Muslim discourses such as literature, art, and music to the fore. Intrinsically paradoxical and polyvocal, Islam can be viewed as a human and historical phenomenon "whereby and wherein truth and meaning are constituted and distributed in particular ways" which, Ahmed claims, "are not adequately captured or apprehended by the concept of religion" (197). Islam as a hermeneutical engagement then serves as a discursive process where the production and accommodation of internal contradiction is fundamental.

In this specific context where the heterogeneity of Muslim populations in the Global North is still overlooked, Muslim diaspora space then emerges as a conceptual tool that magnifies the ways in which Muslims re-inscribe the notions of Muslimness as well as the dominant discourses and ideologies of the western countries in which they reside. It allows for the easing of the grip on ethnic, national, and sectarian origin emphasized within the older framework of "Muslim diaspora" and includes transnational movements of not only people but also of commodities, information, ideas, and cultures. In the following chapters, I will use the lens of Muslim diaspora space to demonstrate how alternative forms of Muslimness find their articulations in the diaspora. 


\section{Conclusion}

In this chapter, I have provided a literature review of the theoretical concepts that guide Muslim diaspora space as a mode of reading. In addition to offering background, I have also argued that the starting point for Muslim diaspora space is the recognition that cultural exclusion, social categorization, Islamophobia, and its socioeconomic ramifications are amplified in the face of today's political realities - and that the antiMuslim rhetoric of othering remains relevant to migrants and citizens of Muslim heritage, no matter how actively they participate in civic projects. However, it is helpful to remember that, like not all Muslim individuals, not all Muslim writers respond to social pressures and cultural racism uniformly. So, what exactly are the characteristics of Muslim diaspora space as a mode of reading?

In short, I suggest that using the analytical framework of Muslim diaspora space as a lens for reading Muslim narratives:

- allows for a reading of Muslim narratives that is not shaped by the author's level of piety; it foreshadows the collapse of all dichotomies that dominate the discourse on Islam and Muslims in the twenty-first century;

- highlights the productive commonalities that contemporary Muslim narratives share despite their differences in style including, but not limited to, complex Muslim characters and a conscious effort to not rely on the stereotypes that have come to define the Muslim subject;

- points to a supra-national space of belonging that escapes the confines of ethnicity, nationality and religiosity through an emphasis on the processes by which Muslim characters, like the writers themselves, reclaim their identity as Muslims and rightful 
citizens of the Global North;

- $\quad$ shifts the discursive focus towards the intersecting subjectivities that fall between the discursive cracks, their existence framed by a rigid dichotomy between fundamentalist and infidel, or secular and pious;

- emphasizes the intersections of Muslimness and "homing desires" in the diaspora-the myriad ways in which Muslim characters redefine Islamic norms as it relates to their desires to feel at home;

- Last but not least, opens up intellectual and critical areas of inquiry by bringing to light how writers of Muslim origin diversify and queer Muslim writing.

The point here is that Muslim diaspora space can generate more nuanced readings of diasporic Muslim experience. Rather than focusing on such over-asked questions as "Is the novel Islamic or secular? western or Muslim? Hybrid or not?” which fundamentally reinforce the dichotomies that we seek to deconstruct, we need to think beyond narratives of singular subjectivities. This discursive shift has in turn the potential to counter the current wave of anti-Muslim rhetoric that has a profound impact on the lived experiences of Muslims in the Global North. Even though the point of departure for Muslim diaspora space is the anti-Muslim, anti-immigration sociopolitical discourse, as I will show in the following chapters, this discriminatory rhetoric is not privileged in this project. Instead, this project brings to focus the ways in which Muslim writers are reclaiming the discourse on Muslimness, undoing the invisibility that the hegemonic discourse perpetually inscribes on the name "Muslim." 
Chapter 2: Recovering Voices and Creating Muslim Spaces: Laila Lalami and Leila Aboulela

\section{Introduction}

Laila Lalami, born in Rabat, had lived in Morocco and the U.K. before she became a naturalized U.S. citizen following her doctorate in linguistics. Her debut Hope and Other Dangerous Pursuits (2005) recounts the untold stories of North African refugees who cross the Strait of Gibraltar in an attempt to start anew in Spain - a theme that anticipated her following novels. Secret Son (2009), The Moor's Account (2014), and her latest novel The Other Americans: A Novel (2019) explore the intersection of immigration, exile, and identity construction, along with sociocultural, political, and economic factors that impact these processes. "Migration is the oldest story of all," Lalami states, "My work is concerned with the transformation of identity, and how migration contributes to that transformation" (Hankir 2009). In a similar vein, Leila Aboulela's work is concerned with the phenomenon of immigration from the Global South to the Global North, along with the cultural, spiritual, and ideological shifts that the process of migration brings forth.

Born in Cairo to an Egyptian mother and a Sudanese father, Leila Aboulela's constant move across the globe - Sudan, Indonesia, Abu Dhabi, the U.K., and Qatarhave informed her writing. In fact, she recognizes "homesickness" as the impetus for her writing (Akbar 2010). In her collection of short stories and novels, The Translator (1999), Coloured Lights (2001), Minaret (2005), Lyrics Alley (2010), The Kindness of Enemies (2015), Elsewhere, Home (2018), and Bird Summons (2019), Aboulela investigates 
shifting meanings of home, belonging and Islam in the diaspora. Aboulela's short story "Museum," which explores preservation of imperial memory in museums, won the inaugural Caine Prize for African Writing in 2000. Without a doubt, Lalami and Aboulela's success is rooted in their curiosity about immigration as a human condition. Moreover, the various ways in which they interrogate Muslimness- rituals, practices, everyday life, history — within the framework of migratory movement reflect a paradigm shift in the context of diaspora from the discourse on assimilation and inclusion to notions of belonging. Reading Lalami's The Moor's Account (2014) and Aboulela's The Kindness of Enemies (2015) through the lens of Muslim diaspora space magnifies precisely this shift. Muslim diaspora space as a framework of analysis puts Lalami and Aboulela in conversation, highlighting their positionality as writers of literary Muslimness, along with their contributions to the emerging literary trends and patterns that unsettle the problematization of Muslims' place in the Global North. A detailed study of the two writers who are shaping the landscapes of Anglophone Arab fiction, transnational American and British writing, and Muslim immigrant narratives is rewarding in itself, and, as I will demonstrate throughout this chapter, is also helpful in highlighting the need to shift our focus from orthodox Islam to how the notions of Muslimness take center stage in various ways within contemporary diasporic texts. In The Moor's Account, Lalami rewrites the failed Narvaez expedition from the perspective of Mustafa, the first African Muslim to enter La Florida in 1527. Álvar Núñez Cabeza de Vaca, the treasurer of the expedition, mentions Esteban only few times, describing him as "the black man," "el negro" in his account that was published as the 
official narrative of the expedition. Lalami moves beyond the rudimentary images of Esteban in her novel while simultaneously calling into question the hegemony of Eurocentric narratives. Like Mustafa, Leila Aboulela's narrator Natasha, the historian, in The Kindness of Enemies (2015) interrogates the construction of history "which could be milked out for this cause or that" (The Kindness 43). Through an emphasis on the myriad ways in which history could be appropriated, Leila Aboulela retells the story of Imam Shamil, the imam of Dagestan and the leader of the tribes of the Northern Caucasus, who became a legend in North America and Europe during his historic battle against Russia in 1839. The Kindness contests the west's exoticization of Shamil as an object that simultaneously signifies "savagery" and "civility," along with "humility" and "pride." Unlike The Moor's Account, which is strictly set in the sixteenth century, The Kindness presents two parallel narratives alternating between modern-day Scotland and the nineteenth-century Caucasus during the Crimean War. However, reading Lalami and Aboulela's works of historical fiction comparatively through the lens of Muslim diaspora space demonstrates how both novels maintain an acute self-consciousness about intertextuality, the master narrative, and re-presentation while simultaneously offering alternative notions of Muslimness that transcend regional and ethnic loyalties.

Both Lalami and Aboulela have received much scholarly and popular attention for bringing forth a much-needed refreshing perspective on the questions of identity, diasporic experience, and belonging. Although it has been acknowledged that their writing transgresses the exigencies of the diasporic condition that prevail in early diasporic literature: anguish, despair, unyielding nostalgia, and so forth, less work has 
been done to analyze Lalami and Aboulela's writing in conversation with one another within the context of Muslim diasporic writing. This chapter is thus invested in studying The Moor's Account and The Kindness of Enemies as part of an emerging literary discourse that resists the ongoing polemicization of Muslim identity in the Global North. Through a close analysis of the novels, I demonstrate the ways in which reading the two texts through the framework of Muslim diaspora space highlights the stereotypical representations of Muslims as part of a historical and political continuum of Eurocentrism and its hierarchal dichotomies.

This reading of the novels reveals that the novels contest such rudimentary representations of Muslims by using imaginative empathy as a trope to rewrite not only history but also the notions of Muslimness. Lalami and Aboulela reimagine history from the perspective of marginalized characters who are pushed to the fringes of history. As they retell their stories, the discursive focus, I suggest, shifts from radical Islam and its history to its shifting construction and reconstruction within the hegemonic discourse. When read through the framework of Muslim diaspora space, this shift, I suggest, unearths a diaspora space in the Global North that is simultaneously Muslim and western - a diaspora space that transgresses the binaries between inclusion and exclusion —and us and them - bringing to light instead the spaces in between difference where "the minority" and "the majority" meet.

\section{Lalami and Aboulela as Writers of Literary Muslimness}

Lalami's protagonists are predominantly immigrants who either identify as a Muslim or were raised in a Muslim culture. However, Lalami (2011) discusses that she 
does not intend to create works of "Islamic fiction" that serve to teach moral lessons to her readers. In fact, "Muslim duties, concepts and aesthetics," she reiterates, "do not uniquely and exclusively affect my writing process" (147). In her reflections on Muslimness and writing, Lalami challenges the assumption that all writers of Muslim origin refer, for instance, to their copies of the Quran and theological texts during the writing process. Instead, she explains that her writing process is ignited by the powers of imaginative empathy — it begins with building a character. She is not concerned with creating halal or haram—good or bad — characters; rather, her writing process focuses on cultivating empathy that allows her to create complex characters who are human and flawed. As she emphasizes, "What makes a good Muslim character is what makes a good character: emotional complexity" $(2011 ; 148)$. Lalami's writing is thus not characterized by a political agenda; on the contrary, her versatile characters render visible the lack of emotional, intellectual and spiritual complexity in Muslim characters in some of the popular neo-orientalist narratives on Islam.

Lalami highlights the connection between this lack of emotional complexity in Muslim characters within popular narratives and the stereotypical representations of Muslims in the media. "In order to reach that emotional complexity," she argues, "the writer must first convince the reader, any reader, through the sheer power of words and fiction, to let go of the perceptions she has about Muslims." The writer's task, according to Lalami, is to tell "the most specific, the most complex, the most truthful story she can tell." However, this is by no means an easy task because it is "that complexity, and that truth which eludes us so much in our perceptions of the Muslim, the ultimate Other of our 
age" $(2011 ; 148)$. Here, Lalami maps out the complex interrelations between the prevalent representations of Muslims in the wider society and how these representations shape readings of Muslim narratives. She points to the tendency to readily politicize Muslim narratives and how the question of aesthetics and subjectivity often recedes into the background - the two important issues that also dominate Leila Aboulela's discussions on writing.

Although Aboulela does not perceive herself or her writing as particularly political, like Lalami, given her topic, she recognizes why and how her work has been received as a form of resistance. If she deemphasizes personal and emotional reasons as to why she writes, Aboulela states, she cannot write at all: "always the characters, their thoughts and emotions interest me more than the political themes" ("On Writing Islamic Identity" 2016). Aboulela seeks to anchor her narratives within an Islamic paradigm, often articulating a sense of heightened Muslimness. However, her writing process begins with creating a character that is emotionally and intellectually complex. Paradoxicallyas the works of literary Muslimness examined in this project demonstrate - this emphasis on imaginative empathy appears to be a key ingredient to the practice of writing as resistance that effectively and successfully transgresses cultural stereotypes that permeate the sociocultural and literary discourses.

Unlike Lalami, Aboulela's Muslimness directly shapes her process of writing fueled by a conscious choice to present Islam as a faith (Chambers 106). In Aboulela's writing, Muslimness does not emerge merely as "part of the culture" or "the social norm," but "it has to do with the individual and their faith, beliefs, and aspirations" 
(Chambers 109). Aboulela is then specifically concerned with the question of religious subjectivity in the Global North and the extent to which it operates as a means of empowerment and liberation for the Muslim woman. However, she emphasizes her characters as flawed individuals who "are not role-model Muslims, but they struggle to make choices using 'Muslim logic"' (Kushkush 2014). As Nash (2012) writes, "the western metropolis is the site from which Aboulela draws her aliment $[\ldots]$ the forces diffused from the globalizing West act so as to draw populations from the East and in the process re-birth them" (47). In other words, the metropolis emerges as an empowering space that allows Aboulela's characters to question and challenge the dominant categories of both Islam and the larger culture.

Even though aesthetics of Muslimness appears in different styles and in different layers in Aboulela and Lalami's works, as writers of literary Muslimness they both engage in the act of rewriting and undoing the prevailing discourse on Muslimness. Aboulela and Lalami are also conscious of their positioning both as "native informants" in Spivak's phrase and model Muslims. For instance, in "Writing Muslims" (2011) Lalami remembers a conversation with a French writer whom she encounters at a literary festival. Their conversation about literature, Lalami recounts, lends itself to a conversation about Moroccan literature, immigration, and Moroccan immigrants in France20. Consequently, the French writer tells Lalami, "if they [Moroccan immigrants] were all like you, there wouldn't be a problem" (144). Lalami finds the fellow writer's

\footnotetext{
20 Lalami emphasizes that "in that specific order," which once again emphasizes the importance of looking
} at the intersection of diaspora and literature and how interlinked they are. 
comment troubling, since the French writer's statement reflects the reductive tropes of "good" or "bad" immigrants_ “ "good" or "bad" Muslims. "Was this man really suggesting that I was a more desirable immigrant because I did not look Muslim?” (144) Lalami asks. She points to the position in which most writers of Muslim origin find themselves: "we had started out our conversation as two equals, two potential friends, two writers discussing literature, but we had ended it as a judge and defendant - the former telling the latter whether or not she would make a suitable immigrant" (144). Lalami's interaction with the European writer is representative of the power dynamics that shape the literary marketplace, underscoring the ways in which the "Muslim" label can be used to define what a Muslim writer should look like, what a Muslim narrative should read like, and so forth. Her anecdote further emphasizes the complex intersection of diaspora literature and the question of Muslimness that has been overlooked within the field of contemporary literature. As Lalami explains, Eurocentric discourse operates on two levels for writers of Muslim origin - it seeks to define not only their identity but also their texts.

A reader's note that Lalami shares in her essay published in The Nation is most telling in this context. "What are you?" the reader asks Lalami in an email, "MUSLIM OR HUMAN BEING. IT'S IMPOSSIBLE TO BE BOTH AT THE SAME TIME” (2012). The misperception that Muslimness negates citizenship and belonging, and in some extreme cases one's fundamental human rights, is still prevalent in the Global North. As discussed in the previous chapter, the stereotypical portrayals of Muslims in mass media shape the modern/western readers' expectations from Muslim writers. In an 
interview, Leila Aboulela specifically addresses the role of literary discourses in this context. "You get books about very fundamentalist characters or you get characters who are atheists and have rejected religion," she states, "In reality there are a lot of people in the middle. But in fiction, there is a lack of representation of the average person of faith" (Clifford 2019). The overwhelming representation of a polarized Muslim identityfundamental (devout) or atheist (liberal) — erases all the alternative Muslim positionalities in between. Reading The Moor's Account and The Kindness through Muslim diaspora space puts a magnifying glass on the Muslim subjectivities that often fall between the discursive cracks in the debates on Muslims and Islam.

It is pertinent to note here -I do not intend to argue that the point of departure for the two texts is the notion of Muslimness, as this would be a reductive reading that dismisses their engagement with a wide range of themes from the paradoxical reality of the past to colonial-postcolonial experiences. Lalami's statement in an interview that The Moor's Account uses Islamic motifs primarily because "that's what the character demanded" (Bady 2014) illuminates why I choose to focus on the construction of diasporic Muslim subjectivity in the novels. Lalami's statement is compelling, but writers who produce neo-orientalist texts about Islam and Muslims could readily make a similar argument, claiming that the development of their Muslim characters, e.g. a terrorist character, an abusive Muslim father, and a Muslim woman who is forced to wear the hijab, requires the frequent use of stereotypical images. My goal here is to demonstrate that The Moor's Account and The Kindness question the established notions of faith, 
identity, and culture — unlike the neo-orientalists texts — without playing on the stereotypical portrayals about Muslims.

By drawing on historiography, Lalami and Aboulela shift the focus from the significant historical events to the nuanced experiences of Esteban and Imam Shamil whose historical representations have been manipulated by the master narrative. The novels offer a de-centered view of Esteban and Imam Shamil by deemphasizing the events that defined them, respectively the Narvaez Expedition and the Caucasian War. This departure from the great historical events recorded and preserved by Eurocentric colonial history then allows for a well-developed and nuanced characterization of Esteban and Imam Shamil as Muslim immigrants who seek to make meaning of their Muslimness and experiences in the diaspora. Lalami-through her narrator Mustafaand Aboulela — through her protagonist Natasha and her complex relation to Imam Shamil - emphasize the relevance of the past in studying the positionality of Muslims in the current political, economic, and cultural settings of the Global North. In doing so, the novels, I argue, concentrate on the fictionality of the historical record while opening up space for alternative notions of Muslimness through the use of Islamic spatial expressions.

\section{Contextualizing Lalami's The Moor's Account: The Politics of Representation}

"When I set out to write The Moor's Account," Laila Lalami states in an interview, "I knew right away who would be telling the story: it had to be Mustafa, in the first person. The conceit here is that he is finally getting a chance to tell us what really happened to the Narvaez expedition" (MacDonald 2015.). Since the novel came out in 
2014, Lalami's retrieval of Esteban's voice has prompted a wave of deserving praise. Deserving, indeed, as it is a crucial intervention in the colonial appropriation of history. Lalami successfully rewrites the Narvaez expedition from the perspective of Mustafa Ibn Muhammad Ibn Abdussalam al-Zamori, the Black Muslim slave who, along with his Castilian companions, survived the quest. Lalami thus offers an alternative to Álvar Núñez Cabeza de Vaca's testimony of the unfortunate incidents that had led to the epic failure of the expedition.

The treasurer of the expedition Cabeza de Vaca penned his narrative, considered the official account of the Narvaez expedition, in 1542 - fifteen-years after the Narvaez expedition set out to the New World from Spain. By 1536, out of six hundred men that made up the fleet, only three Castilians and "the black man" survived: Alonso del Castillo, Andrés Dorantes, Esteban's master, and Álvar Núñez Cabeza de Vaca, and "Esteban," the first Moor to enter La Florida. Cabeza de Vaca and his two Spanish companions endured starvation, illness, and tragedy in most part with the help of the Muslim slave who took on the role of interpreter between the three men and the Indian tribes that they would encounter along the way. Cabeza de Vaca writes:

We had a great deal of authority and influence over [the Indians]. And in order to conserve this we spoke to them but few times. The black man always spoke to them and informed himself about the roads we wished to travel and the villages that there were and about other things that we wanted to know. (153)

Even though Esteban had been an integral part of their harrowing adventure for eight years of exile, Cabeza de Vaca's record of the expedition overpraised the heroic survival 
of the three Spanish gentlemen, relegating Esteban to the periphery despite his pertinent position as a mediator.

In fact, Cabeza de Vaca in his account does not mention Esteban's name at all until the second half of the narrative - although Esteban's master Dorantes is portrayed as an important character in the first half. De Vaca recognizes Esteban for the first time when he recounts the survivors' names after the majority of the fleet disappears: "Alonso del Castillo, Andres Dorantes, and Diego Dorantes, Valdivieso, Estrada Tostado, Chaves, Gutierrez, the Austrian cleric, Diego de Huelva, the black man Esteban, and Benitez" (96). Although it is highly likely that Esteban was able to act as an agent after the unexpected failure of the expedition, Cabeza de Vaca discursively secures the hegemony of the Castilians over both the Indians and Esteban. Esteban in particular is continually referred to as "the black man," and "the Moor" for the rest of the narrative, a nameless slave who merely fulfills his duties to his masters through the act of translating. As Cassender L. Smith (2012) writes, de Vaca's “reference to Esteban's blackness fixes him in an easily identifiable and subordinate position." "No matter what Esteban does in the text, no matter how vital his actions in helping the others survive," Smith emphasizes, "he will always be the 'black man"”(278) as well as the Moor, the exotic Muslim man as represented in the viceroy Marcos de Niza's account of the expedition to the Southwest21. Lalami's retrieval of Esteban's voice thus has incited much debate among readers who 
were curious to read an alternative narrative of the expedition from the perspective of the Black slave mentioned in De Vaca's account.

The popularity of the novel has also raised significant questions about the western production, the politics of reception, and the consumption of Muslim narratives by the western/modern reader. The novel's reception by the reviewers and western readers has revealed the myriad ways in which the desire to read a Muslim writer's text as a sociological artifact is ever so present. My goal in this section is to emphasize the importance of a new mode of reading like Muslim diaspora space by unpacking some of the simplistic readings of the novel, particularly book reviews, that perceive the narrative as part of Lalami's pro-Islamic political agenda against the west. I argue that reading The Moor's Account as purely political and/or as a mere postcolonial project of recuperation of the subaltern figure's agency reduces the intricacy of the narrative. Without a doubt, Lalami masterfully engages in a reconstructive project - a project of excavation of what is omitted from the grand narrative. She further seeks to contest the dichotomies that dictate the space of encounter, in this context the colonial space, introducing a constant shift in power relations between the colonized-the colonizer and the slave-the master. This strategic destabilization of power dynamics in the historical context of the novel opens up the discursive space in which the role of Muslim heritage in the construction of diasporic Muslim subjectivity is underscored. The shift in emphasis on Mustafa within the framework of Muslim diaspora space, as I demonstrate, brings into focus a Muslim space shaped through the ways in which Mustafa makes meaning of his shifting positions and his Muslimness in the diaspora. Lalami does not offer a solution to the current 
sociopolitical climate, but she decries the significance of questioning the histories of systemic colonial/imperial dominance towards the historically marginalized groups, Native peoples, Africans, and other minorities.

Some of the book reviews published immediately after The Moor's Account came out attest to the tendency to place upon the Muslim writer and the narrative the task of politicizing and resolving historical conflicts. One reviewer in The Economist complained about Lalami's unjust treatment of the Castilians. In a book on slavery, the reviewer stated, "almost all the blacks are victims, almost all the whites villains." The review was eventually withdrawn after Lalami’s immediate response. "In ten years of publishing," Lalami responded in a tweet, "I have never once complained about a review. A review is an opinion [...] But I could not let such an egregious misreading of my work go unanswered"(@LailaLalami). The following day, however, another review by Jeffrey Renard Allen for The New York Times critiqued Lalami's portrayal of the Castilians.

In his review, Allen chides Lalami for her predilection for a silenced subject, since he finds the novel "simplistic in its construction of heroes and villains": "The villain always has white skin. Europeans conquer, enslave and erase and are beyond redemption, while the Moors and Native Americans are a people apart." Lalami's depiction of the Castilians, according to Allen, is biased: "The Castilians are greed-driven materialists, while the Moors and Native Americans are, at their core, spiritual beings." "Lalami," he continues, "wants us to understand that storytelling is a religious act." Allen's use of the term "religious" refers unmistakably to the particulars of Islam: "The erasure that Lalami is most concerned about is historical. Namely, how the official accounts have done away 
with the African, Arab, and Islamic role in the construction of the New World" ("His Manifest Destiny" 2014). Allen habitually analyzes the novel through Manichean binaries: colonizer vs. colonized, black vs. white, and Muslim vs. non-Muslim. Lalami's positionality as a Muslim immigrant writer allows Allen to dismiss the complexity of not only the characters within the novel but also of Lalami's multiple positionalities. Moreover, Allen's reading readily ascribes an anti-European/western agenda, which in Allen's formulation is synonymous with a pro-Islamic and radical agenda, to Lalami's writing, revealing that "Islamic," "Muslim," and "anti-western" are all intertwined in the dominant discourse about Muslims and Muslim writing.

Allen's (mis)reading of the novel with a focus on the binary oppositions is one of the many. In her interviews and essays, Lalami discusses the paradoxical ways in which The Moor's Account has been read as a historical document. For instance, she recounts when a disappointed reader asked at a book reading why her portrayal of Esteban is different from his portrayal in Cabeza de Vaca and Marcos de Niza's versions. The image of "the Estebanico we know," to quote Lalami's reader, is directly a product of not only the Orientalist imaginary but also the neo-orientalist exploitation of stereotypes in the context of the western publication industry, circulation, and customer demand. Lalami addresses this cycle of production and demand in her discussion about Marcos de Niza's depiction of Esteban as an exotic ornament. She states:

When you look at Marcos de Niza's version, you hear that Estebanico loved women, and he wanted all these women, and I thought, Oh my God! That is so clichéd. Are you 
kidding me? I'm supposed to take as historical fact that the three Christian men had remained celibate for 8 years but the Muslim guy, oh no, he had to have his harem. As she explains further, "[There is still] this expectation that this guy, because he was Muslim, had to have a harem. And I think there's a little bit of disappointment at that" ("Post45" 2014). Lalami's statement further speaks to the fact that neither the constructed-ness of the historical record nor the stereotypes that construct it are questioned by the majority of popular western readership. Moreover, there is often resistance to the nuanced representations of Muslim characters in literary texts if their portrayal contradicts the master narrative. The Moor's Account and its reception thus raise important questions about the politics of representation. It gives rise to the question: What does it mean to re-write a historical narrative when history itself is "fiction"? To be sure, the ambiguity of fiction vs. history is a pertinent question in the novel. As Mustafa writes at the beginning:

I had journeyed through the Land of the Indians and had witnessed many things that my companions had preferred to revise, embellish, or silence. What had been changed, perverted, or left out was the heart of our history, that part that could not be explained, but could only be told [...] For every lie I had heard about the imperial expedition that had brought me to the edge of the world, I would tell the truth. (The Moor's Account 294)

Mustafa's account highlights that history in the west has been almost synonymous with the Truth since the mid-nineteenth century; therefore, Lalami's integration of a detailed history of the expedition in Mustafa's story blurs the clear line between fact and fiction. 
Mustafa's narrative thus gains authority with its presentation of historical details. In her interview with "Post 45", Lalami further discusses another reader's response to the way in which Mustafa's narrative undercuts any overt distinction between real and fiction:

I'm really fascinated by people who think that the way Cabeza de Vaca described it is really how it happened. I actually heard from a reader, last week, who said, "Oh, I read your book, and you mentioned that they tortured the Indians to find the gold, but Cabeza de Vaca doesn't mention that, and I wonder what your source is." So I have to prove that the torture did happen, but he doesn't have to prove that it didn't happen. And I thought that was really interesting.

Lalami's reflection on the authority of de Vaca adds another layer to the aforementioned question: When history remembers a lie, what does it mean to read a historical narrative written by an immigrant Muslim woman writer? What does it mean for a Muslim writer to re-imagine a marginalized character and contest his subordinate position in the historical record? Lalami herself asks:

Have we imbibed that narrative [Cabeza de Vaca's] to such a level, to such an extent, that no one can question it? Have we absorbed this narrative of conquest to such an extent that even in talking about it in the mildest way, gets you accused of having an agenda? I was amazed by that! If you read Cabeza de Vaca, you can see quite clearly that he has an agenda. But these people [some of the readers and reviewers] don't think so. There's a sense that agendas are something that brown people have. When it's written by an older white male, then it's not an agenda, it's just a fact. (Bady 2014) 
Here, Lalami directly addresses the impulse to attribute a political agenda to "minority" texts in general and Muslim narratives in particular. Her reflection further speaks to the popular trend in the circulation of narratives about Muslims: the re-production of Neoorientalist texts about Muslims and Islam as a response to the increasing public demand to read about "the Muslim we know" and "the Islam we know." The readership's resistance to Lalami's complex portrayal of Esteban, Native American tribes, and even the Castilians is quite intriguing. Given the ways in which Lalami highlights the various operations of power at play in the historical record and unsettle the dominant historical narrative, this, of course, is expected. The defensive responses the text has received reflect how the western literary and cultural production system taps into audience demand and their assumptions about Muslims and Islam. In her analysis of Azade Nafisi's popular neo-orientalist text Reading Lolita in Tehran (2003), Catherine Burwell (2007) points to this intimate relationship between readership and circulation.

Burwell discusses the celebratory embrace of Nafisi's narrative in the post-9/11 context in relation to its "framing"- -its packaging, marketing and circulation—at a time marked by a convergence of the renewed force of imperialism and commodification of culture. She attributes the success of Reading Lolita - along with other neo-oriental texts that have gained unprecedented popularity since $9 / 11$ - to "the presence of framing structures that simultaneously promise white readers reassuring familiarity alongside 'exotic' difference, which reinforces notions of First World centrality and superiority" (290). The question of commodification of postcolonial and "ethnic" texts is by no means 
a new one. Critics and scholars22 have analyzed the politics of circulation and reception, along with the myriad processes through which racialized postcolonial texts are moved from the periphery to the center as marketable, profitable commodities. The reception of The Moor's Account demonstrates the resistance that the popular readership may posit when an "ethnic" text destabilizes the established perception of western centrality. Instead of producing an escape or a victim narrative as is expected of her as a Muslim immigrant woman writer, Lalami presents us with a historical novel that defies the perception of "good" and "bad" in general and the vilification of the Muslim figure in particular. Muslim diaspora space as a framework of analysis brings to light precisely this destabilization of the cycle of production and consumption and its distinct dependence on the dichotomies that have long dominated the literary and political discourses- "us" vs. "them," "civilized" vs. "barbaric," "oppressed" vs. "liberated" — in this contemporary historical and political conjunction.

In what follows, I present a close reading of the novel through the lens of Muslim diaspora space that emphasizes how the text uses such binary oppositions as colonizercolonized and master-slave to transgress them. Muslim diaspora space shifts the discursive focus from the literary text as an ethnographic or historical artifact towards the emerging trends such as aesthetics of Muslimness and imaginative empathy that work to highlight the complex realities of Muslimness, migration, and diasporic experience. An attempt to read the novel through Muslim diaspora space yields not only a deeper understanding of the various operations of power at play in the historical record, but it 
also advances our understanding of the misrepresented concept of Muslimness. This specific reading of the novel emphasizes the important ways in which the concepts of otherness and Muslimness are interlinked in the migrant experience — and it is in this diaspora space of encounter mediated by stability and instability, periphery and center, where the migrant, in this case Mustafa, recreates and reimagines Muslim rituals and practices.

\section{Recovering Voices, Creating Muslim Spaces in Lalami's The Moor's Account}

The Moor's Account opens with a prelude where Mustafa introduces the reader to the events that had led to him penning his memoir. "In the name of God, most compassionate, most merciful. Praise be to God, the Lord of the worlds, and prayers and blessings be on our prophet Muhammad and upon all his progeny and companions," he begins, "this is the humble work of Mustafa ibn Muhammad ibn Abdussalam al- Zamori, being a true account of his life and travels from the city of Azemmur to the Land of the Indians" (3). From the very beginning, Lalami complicates Mustafa's subordination in de Vaca's narrative, and his meditation on his positionality in the prelude anticipates the reconstruction of his subjectivity at the end of the novel. Mustafa overtly disentangles himself from the imperial project, underscoring the interstitial space that he occupies in the New World as "neither beholden to Castilian men of power, nor bound by the rules of a society to which I do not belong." In an attempt to "correct details of the history that was compiled by my companions," he claims to "recount the true story of what happened to my companions and me" (3). As the first person narrative moves back and forth between the historical events that lead to the failure of the expedition in 1528 and 
Mustafa's intriguing past, Lalami not only re-writes the history of the Narvaez expedition through Mustafa's perspective, but she also imagines his birth, childhood, adolescence, and adulthood before slavery, allowing for the development of his character in its own right in a manner not defined by the expedition.

Mustafa recounts his adventures with the Castilians; he also tells the reader about the story of his parents, his birth, his resistance to his father's aspirations for him to be a man of sharia, his past as an affluent merchant, his involvement with slave trade in Azemmur, his unrelenting greed and, finally, his decision to sell himself into slavery. This set of personal details that Lalami charts in the novel is crucial as a trope within the context of Muslim diaspora space. To be sure, as discussed previously, Lalami engages in a subversive project of excavation of what is erased from the dominant history. Her emphasis on imaginative empathy, however, enables her to present the multidimensionality of Mustafa's shifting subjectivity at both ends of the power spectrum-the dominant and the dominated — on various occasions in Azemmur and Seville. The interweaving of his life and the colonial history of Azemmur and the Narvaez expedition reminds the reader that Mustafa had been born into an established imperial system that operated under Eurocentric structures of power and authority. Despite his harrowing journey to the New World, I suggest that La Florida as a diaspora space offers him an alternative space in which he transgresses such established dichotomies between Muslim and Christian, and dominated and dominant.

The deconstruction of his two opposing subjectivities creates an alternate transitional space from which he speaks/writes: a diasporic space in which he reclaims 
his subjectivity by reconfiguring his Muslimness, using the symbols and cultural expressions of the land he inhabits. Mustafa arrives in La Florida with the restrictive Islamic identity that his father coaxes him to assume and his Christian-slave identity imposed on him in Europe. As he learns different Native languages and assumes the role of a translator between the Castilians and Native peoples, these two subjectivities that deny him agency undergo erasure. Through the constant shift in his positionality, Esteban jettisons the exigencies of the restrictive racial, national and religious norms, entering into the process of meaning making of his identity as a Muslim in the diaspora.

From the moment Mustafa decides to sell himself into slavery after the Portuguese invasion of Azemmur in 1513, he is defined and redefined, named and renamed until the discursive reconstruction of his narrativizing self at the end. At the beginning of his narrative, he tells the reader that his decision to sell himself into slavery for the welfare of his brothers after the famine and draught "was a fate worse than death; it was a rebirth into an alien world, with its strange customs and unbearable rules" (114). His enslavement costs him not only his freedom but also his name which "carries inside it a language, a history, a set of traditions, a particular way of looking at the world" (7). In order to record the sale, the clerk asks Mustafa his name: "Mustafa ibn Muhammad ibn Abdussalam al-Zamori, I replied, naming myself, my father, my grandfather, and my native town" (82). As he watched the clerk shorten his name to Mustafa that day, he "could not know that this was just the first of many erasures" (82).

Later, in Seville he is christened at the church as Esteban, "converted and orphaned in one gesture" (109), after which his master Dorantes uses a derogatory 
version of his name to address him, Estebanico. What is curious here is the shift in Mustafa's relationship with his past as a slave merchant, of which he is not proud. $\mathrm{He}$ refrains from resisting the various changes imposed on him, for he views the sudden loss of his name, his voice, and his autonomy as an act of atonement. He reflects on his first day as a slave on the auction block in Seville:

I remembered all the times I had seen slaves in the marketplace of my hometown. I had never thought about these men and women, had never wondered how they ended up in chains...I had passed them and gone about my business [...] Later, out of sheer greed for more gold, I had sold slaves myself. (12)

This crucial detail that Lalami imagines has not been acknowledged in reviews and studies that read the novel as a mere project of recovering the voice of the subaltern. It is overlooked that Mustafa's willful act of selling himself into slavery problematizes the assumption that he is positioned as a subaltern. By allowing Mustafa to decide for himself, Lalami prioritizes the power of imagination rather than the direct subversion of stereotypes legitimized and circulated by western discourse23. Reimagining Mustafa as an agent as opposed to an inherently marginalized figure offers a unique representation of his character that is detangled from the historical record that secured his subjugation. To this end, Lalami also reminds us that the Other cannot be constructed or discussed with no reference to the power (claimed by the dominant culture) to speak for the Other, and that her project as a fiction writer is to "re-present" as in art and philosophy in the Deleuzian sense, not necessarily to "represent," to speak for as in politics. This shift in

${ }^{23}$ As famously discussed in detail by Spivak in "Can the Subaltern Speak?" (1985). 
focus from Esteban as the subaltern to Mustafa and his inherent agency jettisons rather than buttress Mustafa's otherness as a frame to apprehend his difference.

Lalami interweaves stories of Mustafa's domination with instances of his subordination to avoid rehearsing an all-too familiar history. Instead of placing the African Muslim figure into a fixed frame in the diasporic space, she focuses on the ways in which his Muslimness and otherness are interlinked as a dynamic, multidimensional entity. Mustafa's ineluctable otherness is already evident to the reader who is familiar with the expedition; however, the novel encourages readers to go beyond historical knowledge through the very project of decentering otherness. Before his arrival in La Florida, Mustafa occupies the two oppositional ends of the power spectrum; he is dominator as a slave merchant in Azemmur and dominated as a slave in Seville. In La Florida, however, a new paradigm of otherness emerges, as Mustafa finds himself holding the two spaces at once. Lalami is not interested in the project of providing the reader with a fixed representation of the Muslim other. Rather, she presents Mustafa's contradictory subject position that alters in response to the specific circumstances within specific contexts. For instance, when confronted with the Indians for the first time in $\mathrm{La}$ Florida, Mustafa finds himself co-opted into the conqueror's space while maintaining his subordinated status within it. Although he often meditates on his position as a slave to uncouple himself from the imperial project, this is not always the case. Having found gold in the first village the Castilians invade, Mustafa considers himself responsible for affecting the course of the expedition. His rumination on his role in the expedition, precisely in the search for gold, reveals the ambivalence that emanates from his subject 
position. He repeatedly seeks to disassociate himself from the Castilians: "I told myself that I had merely been curious about the kind of fishnets the Indians used. I had not been looking for gold" (12). His guilty conscience prompts him to disentangle himself from the conqueror's project in which he—accidentally or deliberately; we are not certainplays a pivotal role. However, at times he identifies too well with the egocentrism of the colonizer's mind. For instance, at the beginning of the expedition, he often finds himself fantasizing about discovering the gold reserves and returning home (14). In a similar vein, the mirror scene that unfolds after Mustafa fortuitously has found gold points to the complex power dynamics in which he is paradoxically situated.

In this particular scene, the governor, who at this point believes that the fleet is inching closer to the gold reserves, tortures the Indian prisoners until he is "satisfied that they had given him the whole truth" about their gold mines. As the Indians continue to be flogged, Mustafa, who is in the middle of giving his master Dorantes a haircut, sees "both of our [Dorantes's and his] reflections on these opposing mirrors" (12). The literal merging of Mustafa's reflection with that of Dorantes in the mirror reminds him of his status in Azemmur prior to his enslavement. "In my moment of greed," he writes, "I forgot about the cost of my dream to others" (15). He interrogates how (and if) he is any different from his master as he meditates on the crucial role he plays in the search for gold as well as his response, or its lack-thereof, to the flogging of the innocent Indians: "I told myself that I had merely been curious about the kind of fishnets of the Indians used. I had not been looking for gold. Yet the pebble I had found caused these four men, men who had done me no harm, to be whipped" (12). His language here, particularly the ways 
in which he seeks to convince himself of his innocence, implies that Mustafa, in fact, may be responsible for the launch of the invasion. As the cries turn into howls, "I had to pretend," he writes, "like my master, not to hear the cries that had begun to emerge from the storehouse" (12). However, unlike Dorantes who is overtly amused by the incident, Mustafa listens carefully to howls "so long and so filled with pain that" he feels "they were echoing in the depths of my own soul" (12).

This is a key episode in the text that points to the liminal space that Mustafa occupies as neither the colonizer nor the colonized. Despite his involvement in fraudulent transactions as a merchant and in the slave trade, Mustafa, unlike Dorantes and the Spaniards, carries the indelible mark left on him by Portugal's invasion of Azemmur. "Still, I lived with the humiliation of that day," he recalls the devastating repercussions of his country's colonization, “for it had changed my family's fate, disrupted our lives, and cast me out of my home" (10). The juxtaposition of his complex past as a victim of colonial injustice and a perpetrator of slave trade informs the ambivalent space that Mustafa occupies as the Moor in the expedition. Although he paradoxically finds himself ensconced in the colonizer's space in the New World, and may or may not have encouraged the governor's encounter with the Indians, he is still designated as the other both by the Castilians and the Indians who are astonished to spot "a black man among white man," a skin color that is "so different from that of others" (22). The unexpected failure of the expedition, however, transforms the double layers of alienation Mustafa encounters into an opportunity not only to survive but also to recreate and reimagine his identity in the diaspora. 
What complicates Esteban's position in the Indians-Castilians dialectic is the gradual diffusion of the hierarchy amongst the Castilians after the harrowing failure of the expedition24. The survival of only four men out of three hundred enables Mustafa to assert himself, take charge and more importantly, speak, albeit in Indian languages. "We had arrived in La Florida men of different nations and stations," he writes as he recalls Narvaez's lost expedition, "but now the differences between us were not so stark" (136). Through his interactions with the children and women in various tribes that host Mustafa and his three remaining Castilian companions, he learns to speak the Capoque tongue and the Carancahua language. Mustafa recounts how he gains fluency in the Carancahua language after learning the Copaque tongue with the help of the children and women of the tribe. Too often, the Castilians' relationship with the tribes deteriorates as the Castilians refuse to complete the tasks assigned to them. Mustafa thus finds himself "in the space between the Castilians and the Carancahuas, waiting to translate" (201). He helps them resolve the conflicts by translating "faithfully, speaking slowly to make sure I did not corrupt [words'] meaning or lose some of their intent" (201). His role as a reliable translator operates on two levels within the text. It, of course, highlights the integrity of Mustafa's retelling of the expedition. He strategically juxtaposes his efforts to not distort the statements with the Castilians" history of manipulating the truth: "just by saying that something was so, they [the Castilians] believed that it was. I know that these conquerors, like many others before them, and no doubt like others after, gave speeches not to voice 
the truth, but to create it" (12). Mustafa thus not only distinguishes himself from the conquerors, but he also establishes himself as a reliable narrator. In addition, the role he assumes as a mediator restores his agency, for the Castilians have no option but to rely on Mustafa's ability to build and repair the tenuous relationship between them and the tribes. Mustafa's transition from a slave to a translator leads to the drastic shift in power relations within the group; the drastic change he undergoes as a result of this repositioning instigates his exploration of the notions of home, belonging and identity.

As the men move from one tribe's camp to the next in an attempt to survive, Mustafa embraces his position as a translator, which allows him to lead the Castilians. The rapport he establishes with the tribes not only grants him an authority over the group but also uncovers the beauty of "the Land of the Indians" for him. His immersion in nature and the cultural traditions of the tribes emerges as a striking contrast to his past as a merchant. As he gradually learns "to savor what joy was within my reach," he begins to move away from his desire to reproduce his home country in the New World. "Even my appearance began to change," he writes, "Now I allowed my hair to grow and began to braid it in tight plaits along my scalp. I made myself a deerskin vest and a pair of slippers, in the style worn by people of the tribe. These alterations, however modest, made it easier to live with the Yguaces" (213). It is evident, however, that these alterations are not merely a survival strategy for Mustafa. Unlike the Castilians, the connection he establishes with the Yguaces allows him to view La Florida as a place that is real rather than "a place of fantasy" or "a temporary destination" as he used to (213). 
His tentative inclusion into "the Indian space" is juxtaposed with the Castilians' struggle within that foreign space which they cannot seem to inhabit. The Europeans continually expostulate the tasks assigned to them by the tribes and are reprimanded for “interfering with Indian rituals" (219). Esteban's integration into the tribes marks a threshold as the moment his "Moor-merchant-slave-Christined" identity begins to undergo a major shift. Highly conscious of his position as a translator, he writes, "I was no longer a slave, but my freedom had come at the price of being an interloper among the Indians" (224). The Castilians no longer treat him as a slave; in fact, they find themselves in a position of powerlessness as Mustafa observes that Dorantes and Castillo work with him "side by side" (214). In one instance, Mustafa and his companions sit around a fire late at night as he watches "the faces of Castillo and Donates lit by the flickering light of fire, fill with despair." "These faces were, I knew," he remembers, "reflections of my own" (206). Even after the four men marry Avavare women, journey across the continent as healers, and maintain good relations with the majority of the tribes, a shadow of despair and frustration looms over the Castilians as Mustafa begins to feel at home.

Although Mustafa's vacillating positionality throughout the narrative is a source of agony and yearning at times, it is paradoxically his shifting subjectivity that allows him to redefine his relationship to his faith. Born into a Muslim family, he spends his childhood and young adulthood resisting the Islamic prescriptions that his father, alongside the society, has forced upon him. He makes it clear in his narrative that he does not abide by the Koranic hermeneutics in Azemmur. On the contrary, he persistently skips the sharia school to go to the souq where he "watched fortune-tellers, faith healers, 
herbalists, beggars" (23). He further explains how his greed prompts him to get involved in slave trade. In addition, it is implied that he has visited the brothel in Azemmur several times, an act of rebellion against his parents' plea for him to marry. As he suggests, Muslimness for him as a kid meant: "a deep belief in the importance of learning, the necessity of discipline, the rightness of our faith, fulfilling duties, [being forced to] meet the fiqh of our mosque, learn how to read, memorize the Holy Quran" and punishment if these rules were not followed. He tells the reader about a time when he skipped school and got caught by his father who then "kicked me all the way back to the mid, where, upon receiving custody of me, the fqih proceeded to cane my feet until they swelled - my punishment for skipping school." As opposed to the sense of discipline and restriction that his religious father has imposed on him, he also recalls, albeit subtly, another version of Muslimness which is nourishing, explorative and understanding, which reminds him of "[his] mother who nourished me with stories, both real and imagined" (35). However, he stresses that he is not allowed to transgress the boundaries that were already set for him by the mosque, his school, father, and society. It is thus only after he is christened as Esteban the slave in Seville, his relationship to his faith begins to shift as he explores the spiritual aspect of Muslim rituals practices in Seville. But it is in La Florida - when he inhabits the transitional and transnational space between the Indians and Castilians - that his understanding of Muslimness shifts from a set of rules towards a way of living. Mustafa thus claims the ambiguous liminal space that he occupies in the New World as a Muslim space, as he reconfigures what it means to be a Muslim in a new setting in the 
absence of Islamic sounds like the azan, the call to prayer, and other Islamic symbols like mosques and Islamic centers.

As the narrative moves back and forth between his young adulthood in Azemmur and his enslavement in Seville, we see a major shift in Mustafa's perception of Muslimness from a set of strict, restricting rules to be followed towards Muslimness as a process of internal exploration. For instance, although he does not consider himself pious in Azemmur, he tells the reader that in Seville he seeks "comfort in prayer and to speak to my Maker in the only way I knew" by performing the daily prayer. He reminisces about the time when his Spanish master catches him praying after his forced conversion to Christianity: "The sudden weight of a Spanish boot upon my neck silenced my voice [...] I desisted from praying and retreated into silent communions with my Lord" (116). Being compelled to mask his Muslimness as Esteban, he discovers an alternative form of expression of Muslimness that was obfuscated by the rules that his father and the society set in Azemmur. As Mustafa explores the different ways in which one can establish and sustain a connection with God through silence and inner commitment as opposed to external expressions of Islam, Muslimness emerges as a process of meaning-making which reverses the presence of absence that erases his identity as Mustafa.

For instance, his self-identification as "a slave of God" works to negate his positionality as a Christened slave. If we return once again to the scene where Mustafa finds a gold pebble in the first town the Castilians invade, we read Mustafa's reflection on the festivities that were hold in honor of the launch for gold. Mustafa confides in the reader as he seemingly commits a sin by serving the Castilians alcohol. "(Reader, it is not 
easy for me to confess that I served the forbidden drink," he writes, "(but I have decided in this relation to tell everything that happened to me, so I must not leave out even such a detail)" (15). To be sure, this expeditious authorial intrusion appears to be a small detail within the framework of his narrative but examining it through the lens of Muslim diaspora space highlights the significance of a seemingly unimportant detail in Lalami's re-construction of Mustafa's identity. Why would Mustafa include such a detail in the midst of his narrative? Why would he frame it as a confession when he openly tells the reader that he was not a practicing Muslim before he had sold himself into slavery? This authorial intrusion neatly dovetails with Mustafa's promise in the prelude that his account of the expedition is reliable. It also allows him to challenge the slavehood and conversion that was foisted on him. "The officers raised their glasses to the governor," he writes, "to thank him for the good tidings he had brought, and the slaves, including this servant of God, Mustafa ibn Muhammad, refilled them with wine" (14-15). Immediately after he mentions that Mustafa "the slave" serves wine to the Castilians, he paradoxically consolidates his self-subjugation to Allah which subverts his identity as Estebanico the slave. This serves as a means to disentangle himself from the colonial project which operates through the manipulation of religion. His spirituality is constructed in opposition to the materiality implicated in the use of religiosity as a means to secure economic and political power in the expedition. For instance, as Albaniz the notary of the armada claims the land on behalf of the King and Queen upon the Castilians' arrival in La Florida, he states: 
On behalf of the King and Queen $[\ldots]$ we wish to make it known that this land belongs to God our Lord, Living and Eternal. [...]The successor of St. Peter in this role is our Holy Father, the Pope, who has made a donation to this terra firma to the King and Queen. Therefore, we ask and require that you acknowledge the Church as the ruler of this world, and the priest whom we call Pope, and the King and Queen, as lords of this territory. (9)

Lalami's allusion to the colonizer's language masked by religious undertones throughout the novel illuminates the ways in which Mustafa deploys the same tradition in his account—only to challenge it. His departure from a religiosity associated with materiality, power, and discipline as propagated by the colonizers, as well as by his society into an understanding of his faith as a conscious way of living overturns de Vaca's simplistic construction of Esteban. Through a metaphorical enslavement to Allah, Mustafa practices a mode of agency that is intrinsically his own and not bestowed on him by either Eurocentric discourse or by authoritative Islam.

As Mustafa sails farther from home, traveling to the New World, the absence of Islamic cultural expressions inflicts on him a profound sense of loss—of his connection to his family and his city. Initially, Islamic signifiers such as the azan, the sound of Koranic recitation especially during Ramadan and the sight of minarets, among other markers, are interspersed with the notion of home, anticipating the re-configuration of his Muslim identity in the diaspora. He tells the reader that in Seville "I realized why it felt so quiet and empty:" 
In Azemmur, I had heard it [the call to prayer] five times a day, every day of my life. The morning prayer woke me; the noon prayer told me that it was time to eat and rest; the afternoon prayer refreshed me after a long nap; the dusk prayer commended my soul to God. Now I was alone in the world. All I could do to contain the tears that welled in my eyes was to lie in the dark and call silently upon God until I fell asleep.

This quotation is intriguing in that Mustafa equates the lack of Islamic sounds with alienation. Elsewhere, his meditations on his family suggest that Islamic motifs as surahs, prayer beads, and the call to prayer function as cultural markers that remind him of the quotidian rituals of "home" that "would never be mine again":

How I longed to lay eyes upon my mother, to visit my father's grave and whisper a prayer for his soul, to sit by my uncle's side as he built chests or divans. How I longed to be woken in the morning by the call of the muezzin, to be tempted to go back to sleep, and then to feel my brothers' hands gently shake me awake. (318) The loneliness from which he suffers in the absence of Islamic markers is pertinent within the framework of Muslim diaspora space. The emphasis on the intimate link between Muslim rituals and belonging highlights the use of Islamic expressions as spatial metaphors of a place of safety in the novel. In order to conceptualize the diaspora space as home, Mustafa thus infuses his story with Islamic expressions.

For instance, throughout the narrative God "wills" things to happen; it is with God's will and permission that anything takes place, which not only anticipates Mustafa's total surrender to God at the end but also serves as a way for Mustafa to orient and make 
meaning of the diasporic space in which he resides through Muslim rituals and practices. Elsewhere, in his discussion on fear and loneliness during the first few weeks of the expedition, he writes, "I whispered Ayat al-Kursi to myself, over and over the way I had as a child" (123). His frequent recitation of the 255th verse of the Koran's second chapter, often recited when one is in need of protection, serves as a metaphor that evokes memories of home. Moreover, this direct reference to his childhood implies a rekindling of curiosity, purity, and sincerity. As a child, one is not conscious of the ways in which religion is often manipulated by the dogmatic teachings that the society propagates to create and maintain a certain set of order. It would be safe to say that a child's interest in a higher power thus implies an internal motivation, a sense of curiosity and innocence. The absence of the strict rules that led to Mustafa's aversion to Islam as a young adult in Azemmur allows him to return to a state of purity and clarity in La Florida.

We see the drastic shift in his perception of Islam particularly in the ways in which his references to the Koranic injunction are interspersed with folklore, tales, and memories. For instance, throughout the text, he supplements his narrative on the precarious situations that the fleet gets into through proverbs such as "the elders teach us: when the cow is down, the knives come out" (91) and "the elders teach us: if you must drown, let it be in a deep well, not in a shallow pond" (59). Similarly, his references to the Koranic verses are framed as a teaching by the elders: "the elders teach us: "give glory to God, who can alter all fates (105)"; "the elders teach us: we all belong to God, and to Him we return" (159). This framing of the verses evokes the type of Muslimness that his mother practices with its focus on exploration, storytelling, and cultural 
practices - while allowing Mustafa to re-conceptualize his faith as a site of spiritual power.

In this context, his travels through Spain and the Americas become a rite of passage towards self-realization, and his narrative not only rewrites the expedition, but it also serves as a meditation on the ways in which Mustafa has reconfigured what it means to be both a Muslim and an immigrant—an other in the diaspora. The sense of exile, yearning and ambiguity with which Mustafa grapples in Spain and then in the Americas is all part of the diasporic condition. However, La Florida as a diasporic space enables him to disentangle himself from the restrictive ideologies that have long dictated his life, thereby problematizing the rudimentary perceptions of Muslimness. The episode in the novel where Mustafa narrates the physical alterations he undergoes on the Yguance's camp is particularly pertinent in this context. His time with the Yguances charts his reconstruction of cultural and spiritual experiences using the practices and rituals of the received tradition. His memories of the "land of the Indians" as he calls it that at first seem alien to him are gradually entwined with his memories of Azemmur. For instance, he recalls the dance rituals of the Yguance and how he sees the graceful movements of the Yguace dancers reflected in his memories of the souq in Azemmur. "The dancing reminded me of the great feasts we had on market days in Azemmur," he writes, "everyone coming out to enjoy the cool evening, singing and dancing and gossiping until the early hours of the morning" (212). One of those nights, he decides to join the dancers, "at first imitating their movements and later letting the rhythm guide me as I moved about the field with the other dancers" (213). Although the act of dancing with the tribe 
may seem trivial, the lens of Muslim diaspora space brings to focus how his participation in Native rituals foreshadows his shifting sense of home.

For instance, when he first arrives in La Florida, the sense of nostalgia and melancholy is overwhelming. He tells the reader that then "all I wanted was to return home, where I could die among my own kind" (38) and that "memories of my hometown came to me at odd moments [...] when I least expected them, as if my grief liked me ambush me" (39). However, with the shift in the power dynamics within the group as discussed previously, his relationship with Native peoples and marriage to Oyomasot, the daughter of the cacique of the Avavares, allow him to settle into his new life, not out of despair unlike the Castilians but out of appreciation and love. His memories of the azan, Ramadan, and his mothers' tales cease to cause him pain as they are slowly enmeshed with "the lilting branches of a magnolia tree [...] and its fragrant flowers," "peerless evening skies," "the dance of the dragonflies and the fleeting of hummingbirds and "the crickets singing to their mates" (213). A fresh perspective on the rituals of the Indians allows him to quit his attempts to reproduce Azemmur in the New World. It is with this understanding that he is able to: "fashion a new life for myself in the Land of the Indians [...] And so there came a moment when I stopped struggling, when I decided that I would cease making any more plans to return to the old days. I made up my mind to look upon the present as exactly what it was: it was all I had" (234). However, it is not until the plot twist in the novel - where Mustafa and the Castilians are rescued and find themselves in Tenochtitlan - that Mustafa truly recognizes the pertinence of spiritual presence in Islam, 
that as a Muslim he does not require a sacred institution, an authority, or Islamic symbols to belong.

In 1536, eight years after the expedition, Mustafa and his companions encounter a Spanish fleet near Culiacán, Mexico. Mustafa observes the restoration of Castilians' power and a return to the master-slave relationship when he, along with his companions, is brought to New Spain. In the survivors' meetings with the governors, Mustafa finds himself relegated to the periphery once again; his testimony is never asked, he and his wife are not allowed to sleep in the same mansion as the Castilians, and Dorantes fails to grant him his promised freedom in Tenochtitlan. In an episode where Mustafa reminds Dorantes of his promise to find a notary, "Estebanico," Dorantes tells him, "You are one of us, you know that [...] Once we make it [to Mexico], I will find a notary to draft a document declaring you a free man" (272). However, the juxtaposition of Dorantes calling him the derogatory version of his Christian name Estebanico and his claim that "you are one of us" tells Mustafa otherwise.

The stark differences between Mustafa and his companions are further magnified in Mustafa's eyes when he and the Castilians are asked to join a public sermon at a cathedral. Overwhelmed by the sea of people eager to see the survivors of the expedition, Mustafa and his companions take center stage as the bishop delivers his lecture on the mission to peacefully convert Indians to Christianity. "These four Christians you see here," the bishop announces, "have been sent to remind us of the right path" (275). The irony of the bishop using Mustafa as a model Christian is not lost on him. He writes that "I was as far removed from the bishop's idea of a proper Christian as any Indian was. 
Standing in that half-finished church, surrounded by statues of protests and saints, I wondered why God created so many varieties of faith in the world if He intended all of us to worship Him in the same fashion" (275). Mustafa's arrival in Tenochtitlan thus marks a threshold. The act of returning to the city as a survivor with the Castilians is another touchstone for him, for it restores the Christian-slave identity foisted upon him. This confinement that follows his newly-found empowerment in La Florida allows him to reevaluate — and challenge — all the religious, social, and political norms imposed on him. He meditates on the superiority of one religion over another:

This thought had never occurred to me when I was a young boy memorizing the Holy Quran, but as I spent time with the Indians I came to see how limiting the notion of one true faith really was. Was the diversity in our beliefs, not their unity, the lesson of God wanted to impart? Surely it would have been in His power to make us of one faith if that had been His wish. Now the idea that there was only one set of stories for all of mankind seemed strange to me. (27)

Mustafa reveals here a departure from essentialist notions of religion perpetuated by the restrictive teachings of his faith. The juxtaposition of his image as a child memorizing the Koran with his positionality in the diaspora questioning about the dogmatic religious teachings is suggestive not only of the hegemony of outward conformity-mosques, recitals, prayer beads, the azan and so forth—over the internal cultivation of faith, but it also points to the dominant belief in the superiority of Islam among Muslims, as well as in the superiority of Christianity among Christians. It is, he recognizes, the spiritual power that matters within the context of Muslimness, not the Islamic buildings, the 
recitation of the Quran without understanding its message, the veil and so forth. This perception of Muslimness does not necessarily negate the importance of the visible Islamic trademarks; rather, it posits that the practice in itself can precede religious markers. Mustafa thus realizes that by following his companions to New Spain, he has given up "my right to go where I pleased, my right to work as I wished, my right to workshop as I wanted" (297), as well as the ability to practice his Muslimness in a meaningful way. As he writes later, in New Spain he returns to "a world where records were synonymous with power" (287). And this is when he begins penning his narrativein an effort to reclaim his story.

What is curious in this context is, as Mustafa starts keeping a record of the incidents that unfold, his memories of Azemmur and La Florida are merged in a way that produces in him a sense of yearning. Once the religious ceremony is finished at the cathedral, he recalls that "all I wanted was to return to the city I called home" (277). Although he often fantasizes about returning to Azemmur with Oyomasot, he realizes in Tenochtitlan that home is no longer the city where he was born and grew up. Instead, home is where he has become liberated from not only slavehood but also from the confines of religious, economic, and political ideologies that perpetuate restrictive societal norms. Home evokes for Mustafa not only "the rustling of the Umm er-Rbi River, the view of the eleven minarets, the noise of the soul, the taste of figs eaten right off the tree, the pearls of dew that work me when I slept on the rooftop of our house on hot summer nights" but also "the endless expanse of green wilderness, the taste of deer I had hunted, the sound of drums around campfire at night" (296). The growing sense of 
belonging urges him to take initiatives on his own to return home. Therefore, when Dorantes tells him about the new viceroy Cortez's plan to send Mustafa on another quest to the New World in search of the Seven Cities of Gold, Mustafa seizes the opportunity to convince Dorantes to agree with Cortez's plan. Once the fleet arrives in the Southwest, Mustafa and his wife convince the friar that they can explore the Native towns nearby themselves to ensure the fleet's security; they leave and never return. On their way to the Avavares' town, Mustafa spreads the rumor that "Estebanico" was killed (310). Three years after he arrives in New Spain, Mustafa thus achieves to return to "the Land of the Indians," now his as well, with his wife.

Mustafa's decision to disseminate the rumor of the death of Estebanico serves as a transgressive act that reclaims his diasporic identity as Mustafa in the New World. "Estebanico would be laid to rest," he writes at the end, "But Mustafa would remain, free to live a life of his choosing" (320). His wife Oyomasot's pregnancy consolidates the theme of rebirth that emerges with Mustafa's return. He writes: "If my destiny had been to travel west and see this vast, mysterious, beautiful land, perhaps it would be my child's destiny to travel in the opposite direction and see my homeland, which will seem just as vast, just as mysterious, just as beautiful to him—or will it be her? (318)" As the quote above amply bares out, Estebanico's discursive erasure results in the Mustafa's cultural regeneration in the diaspora space. As all outward symbols of ego, power, wealth, and rank are erased after the failure of the expedition in La Florida, The New World emerges as an alternative space in and through which Mustafa investigates his core, who he really is. The move away from the dichotomies between orthodox Islam and Christianity and 
the dominated and dominating allows him to orient the diasporic space in any way he chooses. In spite of the liberation granted to him, Mustafa finds himself organically navigating his new life through Muslim rituals and practices that challenge the hegemony of strict scriptures. His understanding of Islam shifts in focus from symbolic outward activities such as attending the mosque, refusing to consume alcohol in social settings, reciting the Koran in groups, and dressing up in Islamic attire towards an inward commitment and tranquility. As he prays in silence and begins to see God in nature and the essence of Islam in kindness, peace, and understanding, he transgresses the restrictive ideologies that have obfuscated the vision of Islam as spiritual power, a way of living. He still yearns for Azemmur and his family; however, in the very act of living his life through a type of Muslimness that transforms and deepens his relationship to God, we detect a form of resistance to the normative categories of orthodox Islam as well as to his subjugation as the Moor slave.

Although The Moor's Account has received attention as a text that recovers Esteban's voice, I have demonstrated that analyzing it through the lens of Muslim diaspora space reveals that the notion of Muslimness provides the context with which the novel operates this reclamation. This contextualization is consolidated by the structure of the novel. It opens with the name of God, as discussed previously; and Mustafa brings his narrative full circle when he ends it with a reference to a famous verse from Surah AlBakarah. "In my mind," Mustafa writes at the end, "I could almost hear my childhood self intone, together with the other boys in the msid, that to God belong the east and west. Whichever way you turn there is the face of God." As he recalls the tune, he writes that 
"this moment was perfect. It was all I had, and it was everything." In this scene, the verse serves as a backdrop against which Mustafa constructs his new life in the diaspora: "All I wanted was the freedom to lie here in the tall grass, under a darkening sky, with my wife beside me" (318). This scene makes it safe to argue that Mustafa problematizes the idea that he may never return to Azemmur. There is an implication here that so long as he carries his memories and his faith with him in a land and in a language that is no longer alien to him; when his children have the chance to return to his city; when he protects his story from erasure by recording his perspective, he is already home. He repeats Surah AlBakarah as he concludes his narrative: "to God belong to the east and the west, whichever way you turn, there is the face of God. God is great" (321). The very last lines of the novel thus embody the drastic shift in Mustafa's attitude towards his faith, which is focalized around his move from the confines of locality and scripture.

Even though the diasporic space that Mustafa reclaims in the novel does not necessarily point to interactions among Muslims, there is an attempt here to suture together the east and the west, Mustafa and Esteban and home and diaspora. In addition, the novel's focus on the New World as a diasporic space directs us to the overlooked role of Black Muslim slaves in the making of the Americas. Since the sixteenth century, Muslims of North Africa, the Moors and Berbers, figured prominently among the slaves who were sold out of Spain to Portugal and then shipped to the New World. However, as Marwa Hassan writes, the first Muslim immigrants to arrive in the Americans were written out of American history: "The Moor, no longer European or even part of Europe, passed through history, then passed out of history, leaving only traces in the fictions and 
myths as a negative exemplary figure of what not to be. Ergo, Othello" (qtd. In Gana 197). Although The Moor's Account is strictly set in the sixteenth- century, Lalami highlights the strong parallel between the Conquista of the Americas and the war on terror. As she states in an interview:

When I started working on the book, I wasn't at all thinking about the "war on terror," the Iraq War, or any of that. That came much later. But once that came, it was really frightening to notice all the parallels. To notice not just how the quest started and the use of torture, but the refusal to believe that they were wrong, even when the evidence piled up. It's only when it's too late that they start to scramble to get out of Florida. (Bady 2014)

The novel thus offers some significant historical insight into the post-9/11 mythologization of Arab and Muslim identity and into, in Nouri Gana's words, its "historical longevity whose roots shimmer in the recesses of 1492" (229). However, it does so on a hopeful note. Still, Mustafa's interactions with the Native American tribes facilitate the reconfiguration of his identity as well as of the tribes' culture's in the New World. This move beyond difference towards the spaces in between difference through interactions, cultural exchange and, in this specific case, marriage allows for the emergence of an alternate space that is reimagined and recreated by the fusion of differences. To put differently, these intricate encounters transform Mustafa's notion of Muslimness and home, not only generating an alternative vision of Islam redefined by his interactions with the locals but also altering the fabric of his new society. Since The Moor's Account is strictly set in the sixteenth- century, the narrative is focalized around 
Mustafa's act of rewriting himself into history as a Black Muslim Moor. The lens of Muslim diaspora space thus highlights the ways in which Mustafa's quest reveals it is one's Muslim self as an embodiment of Muslim rituals and practice that render any place or time as Muslim space.

While The Moor's Account is more concerned with the historicity of Muslimness in the New World, Leila Aboulela's The Kindness of Enemies uses that historicity to directly investigate the ways in which it has shaped the reformation of diasporic Muslim subjectivity in contemporary society. Moreover, The Kindness illuminates the type of Muslimness that is explored in The Moor's Account through its emphasis on Sufism. Although Sufism is never mentioned in the latter, Mustafa's transformation, particularly his turn to inward devotion, is suggestive of spiritual Sufi principles, which has historically been relegated to the periphery of Muslim existence.

\section{"We belong to Allah and to Him we return": The Sufi Paradox of Submission and Jihad as Resistance in The Kindness of Enemies}

Unlike The Moor's Account that draws a subtle parallel to the Sufi movement as well as the post-9/11 context, Leila Aboulela's The Kindness of Enemies directly explores the position of Sufism in our contemporary political and historical conjecture. The Kindness presents two parallel narratives, alternating between modern-day Scotland in a post-9/11 context and the nineteenth century Caucasus during the Crimean War. As the first-person narrative reveals more about the protagonist Natasha Wilson Hussein, born in Khartoum to a Georgian mother and a Sudanese father, the second person point of view traces the Sufi leader Imam Shamil's rites of passage in the battle against Russia starting 
in 1839. As I will discuss in greater length throughout this section, reading The Kindness through the lens of Muslim diaspora space emphasizes, like The Moor's Account, that it is Muslims themselves and their interactions with fellow Muslims and with the wider society that designate any place as Muslim space. The Kindness further links Imam Shamil's jihad moving across Dagistan, Georgia and Russia into the personal and spiritual jihad of Muslims in the diaspora today. This reading of the novel shifts the focus to Aboulela's exploration of the concept of jihad - its distortions and meanings - as she presents an alternative vision of Muslimness that defies the clichés that render Islam synonymous with terrorism.

Unlike the rest of the writers under discussion in this project, Leila Aboulela's oeuvre is characterized by her attempt to engage with a consciousness that is specifically Islamic. Her characters, however, are often depicted in a nuanced way as Muslims who grapple with their faith and their experiences as migrants. In her interview with Claire Chambers (2011), Aboulela discusses her emphasis on "the non-political part of the religion" in one of her popular romance novels, Minaret (2005)25. "I wanted to write about faith itself," she states, "and how spiritual development is a need which is as valid as urgent as love and career. I wanted to write about the average, devout Muslim and the dilemmas and challenges he or she faces" (112). The notion of Muslimness as a spiritual journey certainly dominates Aboulela's works that precede and succeed Minaret.

For instance, her debut The Translator (1999) narrates the story of Sammar, a Sudanese translator who struggles to negotiate her faith and her love for the Scottish

25 Which I discuss in detail in Chapter 4. 
historian Rae, an atheist to whom she cannot marry unless he converts. Aboulela herself depicts The Translator as "a Muslim Jane Eyre" that, unlike Jane Eyre, presents a Muslim conundrum (qtd In Chambers 109). Although Aboulela has not received the critical attention she deserves, the fresh perspective that she brings into the novel as a form has been celebrated in postcolonial diasporic readings of her works. In his analysis of The Translator, Geoffrey Nash (2012) discusses Aboulela's success in "Islamiciz[ing] the process of 'writing back."” Aboulela's writing, he argues, addresses "the gulf between former colonizer and colonized, showing an awareness of Orientalism without setting out directly to deconstruct the West's image of Islam" (46). John A. Stotesbury (2004) expands on Aboulela's practice of writing back by situating her oeuvre within the context of Muslim feminist thought. Wail Hassan further (2008) situates Aboulela's writing within the context of immigrant narratives, exploring the ways in which Aboulela's works are often "narratives of fulfillment through Islam" (300). Aboulela's anchor in an Islamic paradigm, however, has also led to critical attacks that castigate her for propagating a pro-fundamentalist agenda that taints the secular novel with an Islamic narrative.

In her exploration of religious novels, Sadia Abbas (2011) criticizes Aboulela for offering a conservative vision of Islam in a way that obstructs any, specifically Marxist, criticism of "right-wing Islamism" (455). Although Abbas opens her article with an important question, “can there be a religious novel?", her argument takes an interesting turn as she analyzes The Translator and Minaret to berate Aboulela's decision to "make[s] her heroine's desires consonant with the most conservative interpretation of Muslim injunction, no matter how inequitable" (441). According to Abbas, Aboulela's 
women characters are passive, devout Islamists who seek and desire their own subjugation while shunning or proselytizing the leftist men in their lives. In her discussion of The Translator, Abbas argues as follows:

Aboulela offers up visions of women who seek their own subjection and writes a romance that attempts to dramatize the conditions for what it casts an ideal Muslim marriage, as if she had decided to model the Quranic declaration: "men are in charge of women [...]" Sammar learns from Rae in a way that marks her subordination; she looks up to him; and she is potentially happy to accept the role of a second wife in a polygamous marriage. (443)

Abbas's propensity to read between the lines to highlight the lack of a Marxist perspective in Aboulela's work is quite disconcerting. In addition to perpetuating the western liberal assumption that the Koran endorses male superiority, her claim that Sammar will potentially happily embrace the role of a second wife because she is pious is also a conclusion that is not suggested in the novel. What is even more striking is her discussion of Aboulela's anti-leftist political agenda. "In Aboulela's novels" Abbas contends, "exploring the more traumatic impact of religion upon the world, even in its effects as a powerful discourse, is prohibited, because to broach these issues is a sin, at the same time, a compromise with Empire" (455). Abbas's reading of Aboulela's work as an Islamist political act that disseminates the ideology that "all leftists [...] should be Muslim" (443) is similar to Allen's politicization of Lalami's The Moor's Account. We can then see a pattern emerging in the discussions of Muslim writing, one that points to 
the mainstream tendency to readily attribute a political agenda to Muslim narratives, thereby generating simplistic readings of these complex narratives.

Although Aboulela is not as outspoken as Lalami about her experiences with the readers, she has discussed in some of her interviews how her women characters "practicing Muslims — are sometimes judged by Western readers to be 'passive' and 'unassertive"” (2016). This overwhelming interest in Aboulela's devout Muslim women characters is surely not unexpected as part of the marketing phenomenon of "the exotic." Moreover, Abbas's reading is representative of the criticism that Aboulela's romance novels and the positionality of her conservative Muslim characters within it have received, pointing to the mainstream resistance to alternative visions of Muslimness. By offering a reading of Aboulela's hefty historical novel The Kindness of Enemies through the lens of Muslim diaspora space, I thus shift the focus from the debate on the secular vs. Islamist and oppressed vs. feminist in Aboulela's writing to the myriad ways in which she transgresses such dichotomies in her most ambitious novel yet.

In the novel, the story of Imam Shamil is successfully refracted through contemporary characters who come together in quest of identity and self-realization in the diaspora. The novel is divided into four different strains. Sudanese Russian Scottish history professor Natasha Wilson Hussein's present-day narrative is intertwined with the nineteenth-century story of Imam Shamil who fascinated the west and the Russian Empire with his unyielding ambition and faith during the Crimean War. The nineteenthcentury narrative also charts the stories of Shamil's eldest son, Jamaleldin who was captured by the Russian Czar and of Anna Chavchavadze, the Princess of Georgia who 
was, in return, held hostage by Imam Shamil to get his son back. Through these different stories of yearning and belonging that alternate between the twenty-first century and nineteenth century, Aboulela unravels the mysteries of Sufism as a marginalized vision of Islam and highlights the controversial concept of jihad as an integral part of it. The past, Aboulela demonstrates, can be and should be used as a prism through which we can comprehend the essence of Islam obscured by the prevailing Islamophobic rhetoric in the post-9/11 era.

From the very beginning, Aboulela brings forth the dilemma of Muslim immigrants in Britain within the contemporary sociopolitical context. The novel opens with Natasha's visit to the Scottish countryside to interview Malak, a British Muslim actress, about her ancestry and link to Imam Shamil. Deeply immersed in her research on Imam Shamil and the concept of jihad as resistance, Natasha happily accepts her student Osama's, called Oz, invitation to his mother Malak's house to discuss their Caucasus heritage and to see Shamil's legendary sword that his family inherited. As her interest in the Chechen resistance brings Natasha closer to Malak and Oz, she finds herself unexpectedly thinking and talking about her past. "I was usually restrained, keeping back the shards and useless memories," she writes, "I had worked too hard to fit in. To be here and now. That's how I wanted to appear - topical, relevant, and despite my research interest, inhabiting the present" (6). However, she feels an unexpected sense of security and acceptance with Malak and Oz. The sublime experience of touching Shamil's legendary sword, along with the warm welcome she receives from the family allow her to open up. As she writes, "Here we were, the three of us, fascinated by a common past- 
faithful to it even. I at least to the history, they to an ancestor they were proud of" (47). Later, when anti-terrorism forces storm into the house and arrest $\mathrm{Oz}$ for having downloaded the al-Qaeda training manual on the U.S. Justice Department's website for a research paper, she realizes that she shares with Malak and Oz more than an admiration for Imam Shamil—a sense of otherness.

In Scotland, Natasha strategically constructs her identity as a functional response to her predicament as a "half and half" Muslim whose life is dictated by the difficult work of reconciliation. Through the narrative, she brings up the precariousness of her position "always making a choice, one nationality instead of the other, one language instead of the other $[\ldots]$ nourishing one identity and starve the other" (110). Hers is a story with which most hyphenated identities are familiar. She writes:

I was a failed hybrid, made up of unalloyed selves. My Russian mother who regretted marrying my Sudanese father. My African father who came to hate his white wife. My atheist mother who blotted out my Muslim heritage. My Arab father who gave me up to Europe without a fight. I was the freak. (42) Triply displaced and caught between Muslim Arab "Sudaneseness" and atheist "Russianness," Natasha begins having severe symptoms of anxiety at an early age. She recalls her first anxiety attack that was triggered at a costume party by her encounter with a seven-year-old wearing a wolf's mask. "It was the disproportion of the wolf's head to the child's body, the shock of half human, half beast, the lack of fusion between the two," she writes, "There was no merging. It was a clobbering together, abnormal and clumsy, the head of one species and the body of the other." Natasha's hyphenated self, "the two 
sides of me that were slammed together against their will, that refused to mix" (42), is embodied in her frequent nightmares and panic attacks that reflect her struggles to fit in. Having always "yearn[ed] for an identifiable place where I could belong" (302), Natasha thus attempts to erase her past after she arrives in Scotland with her mother and Scottish stepfather. Keenly aware of her dark skin color and a last name that highlights her Muslim heritage, she legally takes her stepfather's Anglo-Saxon name Wilson and never discusses her past with anyone - until her stay with Malak and Oz. In an effort to further blot out her heritage and to prove her Britishness instead, she volunteers to take on the task of monitoring and reporting the Muslim students who are at risk of radicalization, at the university for the UK Border Agency.

However, Natasha's efforts to fit in appear to be paradoxically shadowed by her research on the concept of jihad and Imam Shamil, which often piques her audience's curiosity at the Q\&A sessions in her lectures. As Dr. Wilson, she frequently confronts the question, "are you a Muslim?" a question that she dismisses as irrelevant. The alternative is not promising either. She reflects on her liminal positionality, explaining that if she had not discarded her father's last name and become Dr. Hussein, she may not have received questions about her Muslimness: "And yet still I would have had to explain the nonMuslim Natasha. Better like this, not even Muslim by name" (6). This rejection of her heritage, Aboulela shows, is not necessarily a preference, but it is a survival strategy, one that ultimately fails. Natasha reflects on the dilemma that faces British Muslims in the current political climate: 
Many Muslims in Britain wished that no one knew they were Muslim. They would change their names if they could and dissolve into the mainstream, for it was not enough for them to openly condemn $9 / 11$ and $7 / 7$, not enough to walk against the wall, to raise a glass of champagne, to eat in the light of Ramadan and never step into a mosque or say the shahada or touch the Qur'an. All this was not enough, though most people were too polite to say it. All these actions somehow fell short of the complete irrevocable dissolution that was required. (6)

At this early moment in the novel thus is a prolepsis of the themes that we will encounter: displacement, alienation, illusion of acceptance, the representation of Muslims, the relevance of the past and so forth. Natasha's meditation on the plight of Muslims in the Global North early in the chapter foreshadows Oz's upcoming arrest and its ramifications for the novel's Muslim characters, Oz, Malak, and Natasha herself.

The predicament in which Oz suddenly finds himself represents the unapologetic vilification of Muslim citizens in the ongoing War against Terror. Not only does the arrest turn Oz and Malak's life upside down, it also marks a threshold for Natasha who is compelled to confront the illusion of acceptance into the society despite her life-long efforts to assimilate. She encounters the harsh reality of Islamophobia that imposes a status of conditional citizenship on Muslim citizens. Oz's Britishness, Natasha shows, is eclipsed by his legal name, Osama. As the anti-terror squad storm into the house, they ask "not for Oz and not for Ossie. They said the other name" (17). Along with a baffled Oz in handcuffs, the policemen confiscate all the laptops and phones, Natasha's included, and Shamil's sword. Natasha points to the chaos and dirt with which they are left in the 
house, noting that the front door had been open this whole time and "the house was freezing" (79). It is not only the house that is freezing in this scene; the scene itself freezes in time, which is consolidated by the shift from the first person past tense narrator to present tense as Natasha depicts how the incident unfolds. This is a key episode in the text that highlights the surreality of the experience and the sense of paralysis that accompanies it. Natasha writes:

[They] say they have a warrant for his arrest. Malak asks why and the answer starts with 't', and ends with a suffix and she draws in her breath. I am glued to the kitchen floor $[\ldots]$ They are everywhere now, lots of them, not two, with their shoes clomping [...] They leap up the stairs, I catch a blur of dark uniform. Footsteps above me. Malak is calling Oz. This makes them angry. They think she is warning him off and two of them run, banging the bedroom door open. (79) The shift in narration here freezes this moment in time and marks it as critical to the development of the characters whose lives are transformed in the aftermath of the operation. It also serves as a cogent metaphor for the dilemma of Muslim citizens in general, highlighting the helplessness and degradation with which those who are readily accused grapple. As such, Aboulela puts a magnifying glass on the emotional and physical suffering that anti-radicalization laws may inflict on particularly those who are falsely accused. The house that is in disarray after the policemen leave, with "sludge on the carpet," "shoe stains on the kitchen floor," "every drawer turned out," "files and books scattered, clothes on the floor" represents not only the violation of the house but also the violation of Oz, Malak and Natasha's privacy and civil rights. Their rights to 
privacy, a sense of citizenship, and a lawful, civil arrest are confiscated along with their electronics during the raid.

The detailed depiction of the incident from Natasha's perspective presents us with an alternative narrative that is often overlooked in sensationalized headlines about antiterror raids. The lingering trauma of such incidents compels those affected by it to redefine their relationship to the society at local and global levels. However, this narrative of humiliation, vulnerability and alienation often falls between the cracks within the discourse on Islam. As Yusuf Awad (2018) shows, Aboulela sheds a light on the consequences of the arbitrary implementation of anti-radicalization programs such as CONTEST and Prevent in Britain. The irrevocable repercussions from which Aboulela's characters suffer reveal, in Peter Morey and Amina Yaqin's words, that such preventative programs in the Global North "are not really so much a consultative exercise as a mechanism for forcing Muslims to take responsibility for acts done in their name, even when they may be separated from such acts by vast differences of space, doctrine, and sympathy" (58). In addressing the devastating results of the counter-terrorism operations implemented haphazardly, Aboulela also brings to light how such accusations and arrests feed into the demeaning representations of Muslims in the media. Natasha recognizes the bias against $\mathrm{Oz}$ on Sunday papers that week:

It was there, why shouldn't it be, pared down, words standing up thin on the page like spikes: A twenty-one-year old man is being held at a high-security area of Glasgow's Govan police station after officers raided a property near Brechin on 
Thursday. His arrest is understood to be related to downloading radical Islamist material. (183, italics in original)

The overwhelming attention to Oz's arrest stands in contradistinction to the lack of coverage on his release which fails to revert the process of stigmatization that $\mathrm{Oz}$, along with Malak and Natasha, undergo. Oz returns home angry, agitated, and traumatized without charge ten days later. But unlike his arrest, his release does not make the headlines. On the contrary, weeks after his release, Oz forwards an article about his arrest to Natasha published on a far-right website under the headline "The Stain of Al-Qaeda has Reached Scotland" (299, italics in original). His arrest secures his position as an interloper who is a threat to social and national cohesion. Malak, too, continues to suffer from the consequences of Oz's arrest; her social circle dwindles, she receives less and less invitations to auditions, and she is interrogated by the counter-terrorism unit about the money she mails to her relatives in Chechnya.

In a similar vein, Natasha finds herself pushed to the margins of society overnight. When her apartment is broken into through the roof that week, she is vigilant and fearful as she hesitates to answer the policemen's questions. Although she is the victim of a crime here, the stigma that accompanies a false accusation of involvement in or with a "jihadist" generates a traumatic cultural separation from the rest of the society. When asked about her phone number by the police, she is careful not to mention that her phone has been confiscated by the counter-terrorism unit. "I stammered and couldn't meet their eyes. My mother's accent crept into my voice," she writes. She further reflects on her vulnerability: 
I started to feel nervous, the truth forcing itself out of my mouth as if it were made up on the spot. Too quickly too easily; gently, politely they pushed me back into the old roles. On cue, my skin flared in their presence, it became more prominent than, what I was saying; and I was now an imposter for asking for attention, a troublesome guest taking up space. They had better things to do and worthier citizens to protect. (108)

It is no coincidence that Natasha's house is broken into as her anxiety over her place in the country worsens. The police tell her to stay with friends until the roof is repaired, and Natasha finds herself unhoused. The temporal experience of homelessness signifies the beginning of Natasha's quest to explore the meaning of home. Her department's response to Oz's case further exacerbates this tension over loyalty, commitment and belonging, highlighting the ways in which Natasha is required to prove her commitment to the nation in order to avoid the charge of disloyalty.

For instance, before Oz's release, Iain, the department chair, castigates her for not having identified $\mathrm{Oz}$ as being at risk of radicalization per her role as the official reporter: “Why couldn't you identify [him] [...] when the police have him in supporting websites that recruit Chechen Jihadist fighters who are linked to al-Qaeda? And what on earth were you doing in their house when he was arrested?" (148). Natasha explains that Oz, as a successful and humorous student who seems merely politically-concerned, has never shown any visible signs of radicalization. But Iain commands her to write the report, nonetheless. Natasha reflects on the precariousness of the situation: 
So I would write that he made snowmen and chopped practised cutting their heads off with a sword.

So I would write that he joked spoke about setting up a jihadist camp in the countryside.

So I would write that he was researching weapons used to use for jihad. (149) Natasha's play on words here is compelling. She juxtaposes the vocabularies that reflect the reality with those that align with the media's dependence on, what Simon Cottle (2016) calls, "the inferential framework of expectations" among their audience, to which they contribute by means of repetition, shaping responses, behavior, and actions (qtd. In Morey and Yaqin 59). The incorporation of strikethroughs in the text serves as an overt criticism of a systematic distortion of the image of Muslims. This passage also demonstrates Natasha's consciousness about her role in the context of the politicized tension between the department and herself. She not only points to the discursive processes by which Muslims are constructed as outsiders, but she also acknowledges her position as a native informant. Although she assumes the role of a reporter in her department "to distance myself. From Hussein and from the titles of my papers" (148), she realizes that her social citizenship both in the department and in the larger society will always be hanging by a thread. As Iain tells her, "You are astute enough to know what needs to be done. You've always been an asset to us, and I want you to continue to be so" (149-50). Iain implies that the act of drafting the report is a performance of national and institutional allegiance, which is reinforced through her interrogation by the police. 
Natasha's conversation with Iain is followed by her questioning by the counterterrorism unit officials about her work on Imam Shamil, her political views, multiple nationalities - and on Oz. Next, her office is sealed off and instantly transformed it into a crime scene. The sealing of her workspace further represents Natasha's separation from the rest of the department. Vulnerable and anxious, she reflects on her image as the "mistrusted Muslim" and how "it now took conscious effort to walk with my held high" (324) despite Oz's release and no formal charges leveled against her. She writes: "Every step climbed, every achievement—all that hard work — had not taken me far enough, not truly deemed me, not landed me on the safest shore" (178). She is thus pressured to write the report and ultimately submits it in order to defend herself against the charges of disloyalty and sedition.

Interestingly, Natasha's involvement with Oz's case is not the only incident that threatens her status in the department. A week before Oz's arrest, the department receives a complaint from Gaynor Stead, a student in Natasha's class, that Natasha has broken her student's finger in class. Gaynor's complaint puzzles Natasha. She is frustrated by the fact that the student can make such a claim that could end her career when Natasha merely perched on top of the student's desk and picked up her notebook to answer a question. As such, she reminds Iain that Gaynor is a problematic student who has made false claims about other lecturers and reassures him that that she did not sit on "her finger or even her pen" (105). "She was clearly irritated by my proximity," Natasha writes, "swinging her hair back sharply and muttering something under her breath. But there was no cry of pain, nothing about a bruised or injured finger" (105). Despite this, the 
department forwards the complaint to The Non-Academic Complaints Panel for evaluation, taking the doctor's report and Gaynor's family's concerns seriously. Aboulela's choice of the Anglo-Saxon name "Gaynor," a historic name that means "white, soft, and fair" is no coincidence. By demonstrating the strikingly different way in which $\mathrm{Oz}$ and Gaynor's individual cases are handled by the department, Aboulela highlights the conditional social citizenship with which Muslims are compelled to grapple.

The department's response to Gaynor's case, though not fair to Natasha, is professional. What is concerning here is the university and the department's reaction, rather its lackthereof, to Oz's arrest and the invasion of Natasha's privacy. Although Gaynor cannot prove her case in the end, the university acknowledges Natasha's perching over her desk "as a violation of personal space" and "a terrible wrong [that] had been done to a student" (323-4). Natasha discusses this double standard, complaining of the student's sense of entitlement. "Too often, I had watched quirky and brilliant students crash and burn," she writes, "Instead it was doleful and dogged Gaynor who was the survivor of the species. Or because she knew her rights and felt entitled to a degree as if she were a client and the university a service" (104). The absurdity of the panel's emphasis on personal space in Gaynor's case is critical and brings to the fore the question of who is entitled to their personal space and who is not in the current sociopolitical climate. For instance, Iain's official request for “every email [Oz] sent [Natasha] and every paper he's ever submitted in your course" (149) does not constitute an offense. In fact, his right to do so is protected by the counter-terrorism programs. Instead of 
evaluating Oz's case or supporting him after his release, when Oz decides to drop out of school, the department breathes a sigh of relief "as if we were well rid of him" (324). Similarly, the department does not offer Natasha any support or apologies when the police officers breach her privacy in her office. As Natasha writes, "To have your personal files examined, to reveal what is exceedingly intimate - a password and search engine history - felt a hundred times worse than having luggage examined at the airport" (175). This juxtaposition of the consequences of Gaynor's complaint with those of Oz's case serves as a powerful symbol that reveals the striking ways in which Muslims are readily pushed to the fringes of the society. The stark contrast in how each case is handled in the novel further showcases the impact of stereotypes, particularly in the face of charges of disloyalty. Tainted with "Muslimness," despite their ethnic, racial, and religious $\mathrm{Oz}$, Malak, and Natasha are all too easily relegated to an a priori conditional social citizenship.

In this context, if we return to the moment of Oz's arrest, Natasha's efforts to clean up and place everything back in its place immediately after the raid cleverly anticipate this irrevocable shift in her status, as well as that of $\mathrm{Oz}$ and Malak. Immediately after $\mathrm{Oz}$ is arrested, the emotional trauma of the harrowing experience leaves Malak shivering, glued onto the stairs and hugging her knees while Natasha finds herself fatigued, "unable to stick the posters back on the wall" (80) and to tidy up. At that very moment, Natasha's desire to make "everything to look and smell and feel like it had before they came" (79) proves to be futile. Instead, nervous and fearful of the future, she falls into a slumber where she encounters a vision of herself as a hybrid creature on one 
of the peaks of the Caucasus. Her seeming defeat after the raid foresees the deconstruction of the illusion that she could hide her Muslimness as well as her multiple nationalities behind the name Natasha Wilson. "From the top of my head all the way down in one straight swoop, I split in two, half-human and half-reptile," she writes: In the logic of dreams I was not embarrassed that I was naked, nor that a part of me was inhuman $[\ldots]$ what perplexed me the most was that I had split vertically rather than horizontally. It was natural to be like a centaur or a sphinx; it was usual to have a full human head. But I had failed; I had morphed into something completely different. $(80-81)$

This is a powerful moment in the text that condenses into a single image, marking the shattering of her reveries on fitting into British society. Here we see Natasha's childhood nightmares resurfacing, uncovering what lurks in her unconscious: a failed hybridity — a threat to her sense of belonging. The hideously misshapen creature that she becomes in her dreams also signifies the contradiction and ambivalence generated by the label "Muslim." As a non-practicing Muslim, Natasha does not practice any of the Islamic tenets, nor does she carry the trademark of visible Muslimness. In the eyes of society, however, her close link to Muslimness, particularly to Imam Shamil, Oz and Malak, in Morey and Yaqin's words, "take[s] the quality of a genetic fault, making one susceptible to infection in the event of exposure to an environment in which extreme opinions might once have been murmured" (42). Despite her efforts to repress her Muslim Sudanese identity, Natasha realizes that the label "Muslim" is foisted on her, and she, too, is a social subject that is confined to the role of suspicious presence. Through her relationship 
to Oz, Malak, Imam Shamil and her Sudanese heritage, she experiences first-hand the ramifications of anti-Muslim sentiments that construct the Muslim figure as an interloper.

Natasha is seemingly defeated in the aftermath of the raid, but Aboulela shifts the narrative from the traumatic repercussions of the arrest to the ways in which Natasha's exposure to Malak and Oz serves as a tool through which she redefines her identity as a Muslim Sudanese Russian Scottish woman. Her deepening relationship with Malak, Oz, and Imam Shamil introduces Natasha to an alternative approach to Islam: spiritual Sufi movement that emphasizes inner devotion. Though deeply traumatic, the incidents that unfold following Oz's arrest act as a catalyst for Natasha's exploration of her faith, the concept of jihad and for her visit to Sudan, which ultimately allows her to make meaning of her multiple identities in Scotland.

Although Aboulela offers a glimpse into the beginning of Natasha's transformation at the end of the novel, it is through Malak, who is a devoted Sufi and a follower of her ancestor Imam Shamil, that Aboulela introduces a type of Sufi Muslimness that that contrasts radical Islam. Early in the novel before Oz's arrest, Natasha listens carefully to the playful discussion on "jihad" between Malak and Oz. In response to Oz's expression of support for political Islam, Malak argues that the notion of jihad has been distorted by radical groups such as the Wahhabis and Salafis; jihad, she explains, refers to "an internal and spiritual struggle." For Oz, this understanding of jihad is a popular contemporary trend created by those who stray from "the True path: "You Sufis $[\ldots]$ with your chants and spiritual retreats," Oz tells her mother, albeit jokingly, "Besides, what choice do you have? Actresses aren’t exactly welcome in mosques? [...] 
You Sufis play down your historical role in jihad. Most fighters against European Imperialism were Sufis. And Imam Shamil is a prime example. He was the head of a Sufi order" (9). Oz's opinion on Sufism is critical within the context of Muslim diaspora space. His response reflects the criticism Sufism receives from some conservative Muslims who view the movement as an unacceptable branch of Islam that does not adhere to the principles of orthodox Islam. In response, Malak reminds Oz of the pivotal role the concepts of defense, reconciliation, and forgiveness played in Shamil's battle against Russia. "Jihad is for upholding the values of Allah," she says, "it is not for scoring political points, it's not for land, it's not for rights, it's not for autonomy [...] Not every Muslim war is a jihad. Not suicide bombers or attacking civilians" (10). Some of Malak's explanations about Sufism throughout the novel may sound like lectures at times; however, Aboulela uses these insightful discussions as a tool to reclaim the meanings of Muslimness, currently hijacked by the Islamophobic rhetoric.

In addition, it is important to note here that contrary to popular belief, it is not only some groups of conservative Muslims that perceive Sufism as a pantheistic belief separate from Islam. As Ron Geaves (2015) demonstrates the origins of Sufism have been the subject of immense speculation for centuries. European orientalists studied Sufism as extraneous to Islam until the beginning of the twentieth century. In fact, the orientalist theories about Sufism suggested that Sufi principles and practices were closely linked to Indian religious traditions, Syrian Christian monasticism, Greek Neo-Platonism and Zoroastrianism (235). In the early twentieth century, western scholars further claimed that the modern revival of Sufi tariqas in the east as well as in the west was "orgiastic 
collectivistic fanaticism" (Max Weber), "primitive aimless spirituality" (F.A.G.

Tholuck), or "folk religion" (E. Gellner) (qtd. In Geaves 238). This historical perspective on the origins of Sufism is crucial, for it supports the argument that the novel's focus on Imam Shamil, one of the revered Sufi leaders, and Malak, a contemporary Sufi in Britain, deconstructs both the Islamist discourse that views Sufism as irrelevant and the western orientalist discourse that refutes its connection to Islam.

The inspiration that Malak draws from Imam Shamil's teachings of the mystical truths of the Koran and inner devotion acts as a segue into the historical perspective through which Aboulela connects the present with the past. Aboulela successfully projects the complexity of Muslim identity from the nineteenth century to the twenty-first century through Imam Shamil as a historical lens. By rewriting Shamil's surrender through the spiritual lens of Sufism, she deconstructs not only the romanticized image of Shamil as an unrelenting barbaric yet heroic jihadist—romanticized by both the west and some fundamentalist groups - but also the neo-orientalist perception of Sufi philosophy as a "gimmick." In this light, revisiting the past illuminates the present and serves as a tool to reclaim the roots of Sufism within Islam, thereby allowing for a new way of thinking about Muslimness. Imam Shamil's leadership in the Caucasian War, his faith, mysticism, family, and surrender received a great deal of attention in the west. Labeled as simultaneously barbaric and heroic, the west's fascination with him constructed him as an exotic object. By the time he surrendered to the Russian Czar in 1859, more than thirty texts and translated editions on Shamil had already circulated in America and Europe (Barrett 359); his surrender, too, led to immense speculation. In the novel, Aboulela 
challenges the orientalist narratives about Shamil, revealing his kind personality, his love for his children and wives, his worries and struggles as a leader.

In the last chapter of the novel, Aboulela delves deeper into Imam Shamil's predicament. After an arduous battle against the Russian invasion, Shamil realizes the devastating repercussions of his ambition: the starvation and poverty his people have to endure, loss of his son and wife, increasing casualties, and more. After Dagestan falls, he spends the entire night with his elder son Ghazi, praying at the mosque and seeking guidance "surrounded by the moans of the wounded and the smell of the dead." His son kneels before him, asking him to consider reconciliation to spare the lives of his children, wives, and people. It is then Shamil meditates on his decision to surrender: "The longer Ghazi knelt before him, the more selfish martyrdom became; the longer Ghazi knelt the clearer it dawned that this was defeat and that defeat was Allah's will. Instead of martyrdom, it was time for Shamil to accept this failure" (314). Despite his vast disappointment and unyielding pain, he surrenders — on the condition that he would be allowed to go on a pilgrimage to Mecca with his family. Shamil's subsequent exile in Russia appears to be a harrowing defeat; however, he soon realizes that his jihadspiritual journey—starts here. Spending his days with memories and his nights in the mosque that he is allowed to build in his courtyard in Russia, he reflects on the unexpected sense of peace that accompanies his surrender:

To be told don't fight anymore, you have done enough, stand aside, stand aside and worship. That was how he interpreted his defeat in Gunaib. It was a command 
from the Almighty to stand aside and worship because the years were running out.

Shamil's reflection reveals an alternative way of viewing his defeat as victory, a spiritual one, through the unique lens of Sufism. "You began to think you were invincible," his mentor Sheik Jamal el-Din tells him later when he visits Shamil in Russia, "You no longer believed that you needed my spiritual support. You began to believe that your naibs were strong and that your tactics were excellent" (319). His teacher explains that he was concerned by Shamil's desire for revenge and victory so he "raised up my palms to Allah Almighty and read Al-Fatiha," the surah in the Koran's first chapter recited for guidance, as well as after burials. Shamil responds:

"As if I was already dead." Shamil did not feel any pain, only interest. "A week later you were captured by the Russians." There was no anger in Sheik Jamal el-Din's eyes, no vindictiveness, no malice. (320)

The Sheik implies that Shamil's surrender can be understood as the annihilation of his $n a f s$, or ego, and his unyielding ambition that has obfuscated the direness of the situation.

Although the concept of nafs is theoretically intricate and remains controversial in studies on Sufism, in this particular scene it is used to emphasize the idea of surrendering the ego and worldly desires. Jamal el-Din's meditation on Shamil's defeat speaks to his failure to maintain his "higher-self," associated with the purification of the soul and spiritual presence. In Shamil's surrender, we then see the Sufi dictum "die before you die" which often refers to the death of the "lower self," physical impulses controlled by emotions and ego. Sheik Jamal el-Din's confession of his role in Shamil's capture gains 
in importance in this context. Through the death of his nafs and ambition that was merely wreaking havoc on his people, Imam Shamil returns to the path of restoring his relationship to Allah and to his teacher- hence to the state of spiritual presence, ma'rifa described as "the direct knowledge of self and God that flows freely in the purified heart" (Chittick 40). Through the candid dialogue between Shamil and his teacher, Aboulela offers a new understanding of Shamil's battle against Russia. By reimagining the ways in which Sufi principles, as well as "spiritual support" and "blessings," took center stage in Shamil's victory and defeat, she contests the historical narrative about Shamil's mystical powers and the degradation he suffered in captivity. As Shamil states, "let the Russians think what they wanted to think. Let them understand in their own logic, in their own language how he resisted them for decades and why, almost overnight, he fell” (320). Aboulela thus discursively enacts the death of the Shamil that the west has imaged. The deconstruction of the romanticized image of Shamil serves as a tool through which the novel challenges militant Islam and offers alternative visions of Muslimness that have fallen between the discursive cracks.

The critical parallel that Aboulela draws between the past and the present here is compelling and is underwritten by a scene after Oz's release where Natasha and Malak discuss the threat of violence enacted in the name of Islam. "What would Shamil have done?" (226) Natasha asks. Malak's cogent response deflates the problematic ideologies that propagate a unidimensional Islam that fails to exist in the presence of other religions, beliefs, and alternative ways of living. Malak says: 
He would have seen through these militants, — that they "fulfil neither a contract nor a covenant. That they call to the truth but they are not its people. He would have gone after the hate preachers who say to the young men of this day and age, "go out and make jihad" [...] Shamil would have gone after these bigoted preachers. (226)

Malak's answer reflects Jamal el-Din's principle for peace to "reconcile, negotiate, and forgive" (The Kindness 65). Aboulela juxtaposes Shamil's transformation with "the utter contempt" that modern militant groups harbor for "Shamil's traditional spirituality" and "the choices [he] made at the end of his career" (227). In doing so, she highlights the relevance of Muslim history to the Muslim present by, in Mariadele Boccardi's words "conflate[ing] the past with its representation in the present because both belong to the same linear, continuous, homogenous historical reality" (14). She also calls into question the hegemony of the scripturalist claim to be purified Muslims. The novel's inquiry should not be mistaken for advocating passivity and submission or a disavowal of Muslim political subjectivity. On the contrary, Shamil's ultimate defeat reflects the Sufi principle that one needs to understand their limitations and inadequacies, that "we are far from the Real, far from wholeness, and far from balance," (Chittick 85) in order to cultivate a "higher self." Aboulela emphasizes the pertinence of shifting the discursive focus from outwardly activities, exteriority, and the strict rules of sharia to practicing an inward-looking version of Islam that has, for centuries, been relegated to the periphery. Moreover, the gracious way in which Shamil handles his captivity and his homesickness demonstrates that martyrdom is, in fact, the path of least resistance. Shamil's surrender 
suggests that internal jihad - prioritizing that which matters the most to a believer: spiritual presence, restraint, and self-discipline - remains the most challenging task on the path to establishing a relationship with God.

Through her focus on Sufi principles, Aboulela highlights the critical role internal jihad - the arduous processes by which we strive to make meaning of self and what it means to be a Muslim — plays as a form of resistance that is obliterated by militant Islam. Like The Moor's Account, The Kindness is focalized around the ubiquity of Islam—-that one does not necessarily have to be geographically tied to an Islamic nation to make sense of their Muslimness, nor does one require an authority figure or an institution to connect with God. In fact, as Shamil reflects, "reciting the Qu'ran in a place where it had not been heard before, kneeling down on a piece of earth that had never been pressed by the forehead of a believer" (316) rejuvenates one's spirituality through the continual act of $z i k r$, remembrance. Aboulela suggests that the Sufi principle of remembrance, that one can see God in themselves and things if one is continually aware of God, can in fact be enhanced by the absence of Islamic signifiers.

This is exemplified in a key episode in the historical plot where Shamil's cynical wife Zeidat, the daughter of Sheik Jamal el-Din, berates the sound of the church bells. "Must the Russians have all this clamour to remind them to pray?" She retorts, covering her ears with her hands (315). Shamil asks her to listen carefully. "Your heritage should have given you more sensitive ears," he replies, "they are saying Haqq! Haqq! They, too, can remind us of Allah. If you listen carefully, you will hear them say His name. Truth! Truth!" (316). The truth to which Shamil refers here is the reality, which to borrow 
Chittick's words, "is nothing but the plain act of God's activity and presence in the world and the soul. To remember God in His activity and presence is to remember Him as $\mathrm{He}$ is, and this is to see that there is nothing truly real but the Real" (63). Aboulela thus points to the contradistinction between Zeidat's Muslimness and her overemphasis on the outwardly activities that impede the cultivation of her spiritual connection to God. Shamil's comment on Zeidat's propensity to view signifiers of Christianity as a threat appears to be a message delivered to contemporary Muslims who find their Muslimness disrupted by the diasporic experience or who resort to violence in the name of Islam. As Malak tells Natasha before Oz's release, " $\mathrm{He}[\mathrm{Oz}]$ has-as I have- a heritage which is moral and thoughtful and merciful. Did he honour it? Or did he choose to go along with those who claim they're acting in the name of Islam and at the same time don't follow the principles of submission and restraint?" (185). As a prominent Sufi leader, Imam Shamil serves as the historical voice of spiritual traditions of Muslimness in the novel, his principles explicitly challenging the hegemony of radical Islamist claim to be the authentic Islam.

Reading the novel through the lens of Muslim diaspora space thus highlights Aboulela's emphasis on the often-overlooked historical fact that Sufis have escaped national and ethnic loyalties as travelers who have sought both spiritual rejuvenation and ways to bring Islam to new territories (Geaves and Gabriel 2). Through her emphasis on Shamil's spiritual transformation in the diaspora during his journey from Dagestan to Russia, the Ottoman Empire, and finally to Mecca where he passes away, Aboulela shows that a return to the spiritual traditions of Islam can guide Muslims who find 
themselves in a double bind towards a type of Muslimness that transgresses ethnic, racial, and national boundaries.

As the historical part of the novel charts Shamil's internal jihad, Natasha's personal jihad to make meaning of her identity in the aftermath of Oz's case progresses further. After Natasha is compelled to submit the report on Oz, she flies to Khartoum to visit her estranged dying father. Upon arrival, however, she learns that her father has passed the previous night. Instead of leaving, she decides to spend time with Aunty Grusha and her son, Natasha's childhood friend Yasha, a Russian family to which she and her mother remained close in Khartoum. As she reconnects with memories of her father, Natasha unexpectedly finds herself in the middle of a family inheritance feud. According to Sharia law, she is informed, her father's estate would be divided in descending order of proportions between Natasha, her half-brother, and her stepmother Safia. Natasha understands Safia's strong opposition to Natasha's legal right to her latehusband's estate. "After twenty years of absence, after discarding her father's name, after moving further and further away from any semblance of Sudanese identity,” she reflects, "this Natasha Wilson has a greater share of the roof that is over Safia's head" (266). However, she cannot overcome her frustration when she learns that Safia sues Natasha to prove that she is not a Muslim and hence legally not an heir. Disheartened and perplexed, she tells Yasha, who is also her lawyer, "So, let me get this straight. I am to go to court and prove that I am a Muslim? I haven't got a leg to stand on. Nothing. I am not even sure if I am" (293). Natasha, shaken by the absurdity of the situation and a heightened sense of vulnerability, is tempted to return to Scotland. However, her friends' support 
encourages her to stay and win the case - not to receive her share but to prove that she is, indeed, a Muslim. In an email, Malak urges her to confront the judge: "Yes you are a Muslim - fight for it [italics in original]" (298). Similarly, Yasha tells her that "You shouldn't have to prove that you are a Muslim, you are one by birth, by default. You have a right, to be a bad Muslim, a lapsed Muslim, a secular Muslim” (293). Yasha’s response is quite compelling and reflects the wider struggle of Muslims who do not fit into the box that the scriptularists and the west tailored for all Muslims.

By juxtaposing Natasha's friends' responses with Safia's accusation, Aboulela not only draws attention to the debates about Muslimness and Islam, but she also calls the hegemony of prescriptive Islam into question. Natasha's legal battle to prove her faith in court raises the following interlocking questions: Who has the authority to decide one's level of Muslimness? Is one required to carry the trademark of visible Muslimness - a Muslim name, a beard, a hijab, and so forth—to identify as a Muslim? Natasha's reflex to leave Khartoum exemplifies the conditioning that has shaped the perception of mainstream Islam. Natasha assumes that she does not qualify to be a Muslim, for she perceives herself — and is perceived by Safia - as an outsider who does not bear the characteristics of a Muslim woman as dictated by the Islamic doctrine. She recalls Safia's outburst: "You don't want his [your father's] name anymore. What does it say in your passport? It doesn’t say Natasha Hussein anymore. But why should we expect any better of you? Your mother was a slut and you're no better" (266). Aboulela's emphasis on Natasha's passport and her name indicates that Natasha's Muslimness cannot be explored with no reference to her sense of belonging. By allowing Natasha to stay in Khartoum 
and defend her identity in court, Aboulela enables her to delve into the feelings of yearning for home. In doing so, she empowers Natasha to explore her Muslimness in a way that escapes the confines of authoritative Islam.

Having decided to wait for her court date, Natasha revisits her childhood "homes" and her old friends. It is when she visits her stepdad's house where she and her mother used to live after the divorce, she recognizes the "ache I could not first understand" as "homesickness" (302). The empty mansion, now cracked and rusty, serves as a metaphor for the fleeting nature of home for Natasha who moves back and forth across cultures. As she meanders about the city that is familiar yet unfamiliar and the houses that store countless memories, she confronts the questions: where exactly is home? Is it the house in which one lives? Is it the country where one resides? Is it the space where one makes memories? Natasha inches closer to an answer as she catches up with her friends, "other cross-cultural families in which the mothers were Eastern European and the fathers Sudanese" (300). Surrounded by people who, like herself, switch from Russian to English to the Arabic words and who move between cultures and countries, Natasha's anxieties over the bifurcation of her identity begin to dissolve; for the first time she finds herself in "an identifiable place where I could belong" (302). "So this was the tribe I belonged to," she writes, "here were my species" (300). She writes as follows:

I valued the sense of belonging Grusha and Yasha gave me, the certainty that I was not an isolated member of a species but simply one who had wandered far from the flock and still managed to survive, for better or for worse, in a different 
habitat. Chatting with them, we would skip from Russian to English to Arabic and I relaxed without the need to prove, explain or distinguish myself. (324)

This quotation reveals that the farther away Natasha has attempted to move from her past, the more she has struggled to make meaning of her identity. The sense of certainty and belonging she experiences in Khartoum is juxtaposed with her daunting efforts to prove her Britishness - to the university, the police, her students, her colleagues - in the aftermath of Oz's incident. Paradoxically then the accusations that she faces in Scotland about her loyalty to the society and from Safia in Khartoum about her "non-Muslimness" empower Natasha to recognize the layered identity she has constructed over the years to fit in. The support she receives from Malak and her friends in Khartoum further facilitates the realization that she does not have to choose one culture over another and one identity over the other.

In Khartoum, Natasha recognizes that her culturally polyvocal identity as a Muslim Sudanese Russian Scottish woman, represented amply by her names Natasha Hussein Wilson, has merely been buried under the life-long struggle to prove her allegiance to one country or another. The core, the foundation, however, has always been there. The memories of her now-deceased parents and the smell of the dusty, humid city merge with the sound of the call to prayer, her memories of Ramadan, and her grandmother's prayers, reminding her that "Childhood psychologists say that the first five years are the most formative. I have spent them all here [...] All the other layers on top could not obliterate this core" (261). The court scene further attests to the beginning of her transformation. As she confronts blunt, intimate questions about her faith in the 
courtroom, she tells the judge that she may not be "a good Muslim," but "not a bad person either." She discusses her desire to give up her share of the inheritance to her halfbrother with whom she hopes to keep in touch. She writes: "I said I did not come here today to fight over money or for the share of the house. I came so that I would not be an outcast, so that I would, even in a small way, faintly, marginally tentatively, belong" (303). Natasha's victory not only proves that she, indeed, belongs, but through her victory, Aboulela also highlights the ways in which the Islamic laws could be distorted. Safia's argument reflects the hegemonic claim to authentic Muslimness; however, the judge's ruling in Natasha's favor and his encouragement for Natasha to "practice it [her religion] as best as you can" (303) serves as a compelling symbol that contests the conservative ideology that propagates a single vision of Islam that is rigid and stagnant. In other words, Aboulela calls the subjective notion of "true Muslimness" into question. With a support from old friends and Malak's spiritual presence, Natasha is able to reclaim her memories, as well as her multiple identities. Her relationship to her faith, however, undergoes a drastic shift when she returns to Scotland with a renewed sense of belonging.

The final chapter of the novel which charts Natasha's meeting with Malak at the Dunnottar Castle is particularly important within the context of Muslim diaspora space. Aboulela shifts the focus from the sociopolitical objectification of the Muslim figure as a subject of radicalization to the ways in which the Muslim individual makes space for both Britishness and Muslimness. A few weeks after Natasha returns from Sudan, she receives 
a call from Malak asking her if she is free to meet at the Dunnottar Castle26 in Stonehaven. Aboulela's decision to end the novel at a site that bears spiritual and historical importance for the Scottish is no coincidence. The medieval castle, today comprised of remains, brings the novel's different historical trajectories together beautifully. Both Malak and Natasha engage in a symbolic, imaginary reconstruction of the site as they paradoxically seek wholeness as British Muslims within it.

Aboulela's reference to the castle as a unifying motif is evident, as the reader follows Natasha after she buys a ticket and wanders around the evocative ruins in her search for Malak. The detailed, descriptive scene almost becomes interactive as Natasha lingers around the headland, takes in the view, touches the moss-covered walls and climbs up the ancient stairs. "Here_-I reached my hand out_-" she writes, "were the stone walls on the cliff $[\ldots]$ large holes from which guns once stuck out" (326). The sublime atmosphere around the castle axiomatically reminds Natasha of its ancient history: the moment when Mary, Queen of Scotts visited it and the time when the castle stood as the only remaining place in Scotland where a small garrison loyal to Charles II resisted Cromwell's army. Realizing that she is distracted, she writes, "but I was here to see Malak and she was somewhere inside, waiting for me" (326). However, we understand the importance of the castle's ancient history when, after a long walk, Natasha spots Malak dressed in a kaftan and a turban in front of the chapel, reading a hard-backed book which, when she inches closer, recognizes as the Koran.

26 The medieval castle, now in ruins, sits proudly on a clifftop by the shoreline. Having been considered the gateway to the mainland, it played a pivotal role during the Wars of Scottish Independence. 
The Dunnottar Castle, as a spiritually and historically pertinent site for the Scottish, embodies the spaces in between difference that highlights the visibility of sameness rather than differences among the citizens/residents of Scotland. In this context, the image of Malak in a turban with the Koran in her hands serves as a tool through which Muslim identity is re-inscribed into social, cultural and geographical spaces in Britain. For instance, once finished with her recital, Malak tells Natasha about her Quran tour around the country. "Everyday I go somewhere different to pray and read a section," she says, "I’ve travelled up and down the country" (326-7). Malak's tour of Scotland demonstrates the ways in which she heals from the devastating ramifications of Oz's arrest. Rather than withdrawing from civil society following the incident, she reclaims the territory in which she lives as a rightful citizen. Within the context of Muslim diaspora space, her tour then can be read as a subversive act of undoing the derogatory labels foisted upon her, as she makes space as a Scottish Muslim on British soil. "Yesterday, I prayed further north," she continues, "In the middle of a suburb which was so artificial and depressing that I almost couldn't bear to be there. But I stuck it out, telling myself that I would be the first one there ever to say the word "Allah" (327). Her perseverance to stay and pray in a neighborhood where, unlike cosmopolitan London, she is highly conscious of her dissonance evokes Imam Shamil's endurance in Russia where he finds solace in the idea that the practice of remembrance and worship does not require a sacred place.

Malak also tells Natasha that she has visited "spiritual spaces like Stonehenge where [she has] often sensed a powerful presence." She adds, "this [Dunnottar Castle] is 
one of them, can you feel it?" (327). Natasha responds that "Centuries ago, people in this very spot worshipped as you were worshipping just now. They believed like you believe. And centuries ago, as Covenanter history teaches, they also waged wars, resisted and rebelled around issues of faith" (327). Given her position as a historian, Natasha's reference to the ancient history of religion, migration, and resistance in Scotland is expected. However, her response also highlights Malak's place — by extension, that of British Muslims as a whole_-as an integral part of the Scottish past and identity. Malak's emphasis on powerful spiritual presences at historical sites points to these spaces as symbols of the past as well as portals into it. The aesthetics of ruins in this context reveals, in Florence M. Hertzler's words (1982), a moment of human encounter with a human encounter in another time, as ruins are part of the cosmic process that is somehow united by time (106). Beside projecting temporal and historical paradoxes, as Catherine Slessor (2017) states, ruins also embody "contested projections of meaning and memory" ("The Architectural Review"). In this scene, both Natasha and Malak engage in the process of adding meaning to the historical and spiritual importance of the castle. They reimagine the archeological site and situate Muslims' struggles in the twenty-first century within the long historical continuum of migration and identity struggles in Britain. At that very moment, the spirit of Imam Shamil and the spirits of those who prayed on the same spot over the centuries merge with Malak and Natasha's presence. As Natasha describes Malak, "the other visitors must have thought she was in medieval costume; if she popped up in the background of one of their photos, they could claim that they had spotted a ghost” (326). Natasha's depiction illuminates Malak's organic integration into the site- 
by implication, into the wider society — exemplifying the symbolic convergence across time and space.

Moreover, the lens of Muslim diaspora space further points to the importance of the scene at the castle, highlighting the ways in which it links to another key episode in London. When Malak invites Natasha to a zikr session in the city, Natasha observes for the first time how Muslimness is redefined in a way that underscores harmony, inner devotion, spiritual presence and remembrance. Performed by the same Sufi movement Imam Shamil belonged to, the $z i k r$ introduces Natasha to a type of a Muslimness that "delves deeper into the hidden truth behind the disguise" (329) as well as an ethnically and racially diverse Muslim diasporic community whose shared Muslimness is reimagined in the Global North. Natasha writes:

Malak's modern zikr was held in a North London dance studio. Floor-to-ceiling mirrors, cushions on the sprung hardwood floor, barre all the way round $[\ldots]$ ' The man in the navy jumper over there,' Malak whispered, 'is an aristocrat, closely related to the queen.' She then pointed out a well known photographer, an architect and an aromatherapist. Dumpy Asian housewives, extravagantly handsome Nigerian men, hippies and new Agers. I wondered what Shamil would make of this lot. His legacy reaching Britain in this way, tame but undisciplined, capacious and gently accessible. (228)

Natasha's meditation on the pluralism of the Sufi tariqat as Shamil's legacy is crucial. Her comment underlines the reconfiguration of Muslimness that escapes the confines of race, ethnicity, and nationality in the form of British Sufism that has gained in popularity 
in Europe and North America, as well as across the Muslim world. Geaves and Gabriel (2013), for instance, demonstrate the transcultural and transnational texture of the most Sufi orders that transcend their origins in Pakistan, Bangladesh, Malaysia, Turkey, Iran, Yemen, and North-West-East Africa (2). Geaves (2015) further maintains that the current British Sufi scene "carve[s] out a new cultural and religious space that creatively interacts with the new environment of Britain." He explains as follows:

The tariqas have become more aware of the need to draw upon the transnational and trans-cultural nature of globalized memberships and to articulate the narrative of tasawwuf and traditional Islamic sciences in an intellectual environment, address both Muslims and non-Muslims in the lingua franca. (254)

Malak's zikr session in London represents this contemporary Sufi scene that has developed in the twenty-first century in the Global North. Aboulela brings to the light here a type of Muslim ritual and practice that remains invisible to both scholars and general public as other aspects of Islamic religiosity have dominated the discourse on Muslims for political and security reasons. We see Natasha closely observe the prayer session as the members form circles on the floor around the German sheik. In a way that connects this moment of worship with that of Shamil, the sheik begins the session with a brief discussion about the importance of taming the ego.

As the Sheik's words merge with the rhythmic chant, Natasha's experience embodies the Sufi principle about the pivotal role of intention and awareness in escaping the confines of the mind and the body. Natasha closes her eyes and listens, but her concentration on the zikr is disrupted by her intrusive thoughts about her weight and the 
discomfort of sitting on the floor- knees aching, pins and needles tingling in her feet. Overwhelmed by the spiritual energy surrounding her, the feelings of heaviness and enlargement leave her weak on the floor: "Like I weighted a ton and I was taking up too much space $[\ldots]$ And I could see now that there was too much distance between myself and the outskirts of myself, between my core and my edges. Too much distance to travel on my own" (229). Her physical and mental reaction to the $z$ kir reflects her resistance to exploring her true self that she has hidden behind the name Natasha Wilson. The prayer session marks a threshold for Natasha, a moment in time that anticipates her efforts to reconcile between who she truly is — core — and who her passports say she is — edges-. During the prayer, she recognizes the need to connect to her core, her higher self, which will enable her to accept both her core and edges as she probes the meanings of Muslimness and Britishness, following Malak and Imam Shamil's lead.

The juxtaposition of the $z i k r$ scene with Malak's recital around Scotland then is crucial as episodes where Aboulela create contexts that enable Muslim characters to interact with one another and relate the larger society. The former points to religious interactions among diverse Muslims, which then turn to interactions with the wider society represented by Malak's tour. Malak's Muslim community, despite their ethnic and racial differences, cultivates a kind of Muslimness that allows them to make meaning of their lives within Britain's political, economic and cultural contexts. As represented by Malak's Koran tour, their presence as Muslims is sufficient to characterize Britain as a Muslim space; at the same time, Britishness shapes their practice and ritual as exemplified in the $z i k r$ scene. 
To return to the metaphor of the ruins, the concepts of Britishness and Muslimness, just like ruins, retain their power and resist time; however, they also connect with space, and their meanings are recreated in new settings and through new influences. Malak's active reclamation of her British Muslimness then contests the established notions of authentic Muslimness as well as authentic Britishness. Through her practice in dance studios and wide-open spaces, she reclaims the territory in which she resides and refuses to be stripped of her British citizenship. Simultaneously, her Muslimness undoes the historical appropriation of Sufism by European orientalists and restores its philosophy as an integral part of the Koranic tradition. And at the end of the novel, Natasha is ready to join Malak and begin her own journey. She reflects on her meeting with Malak at the castle: "I had come to her [Malak] today needing to connect, wanting to spend time in her company. Perhaps it was time to acknowledge that what I was after was spiritual. She was ready to be a guide and I would fight my weaknesses in order to follow" (314). Aboulela's layered historical novel thus offers a vision of Islam that requires a deeper engagement from the reader beyond the reductive tropes. Both the contemporary and historical plots chart the challenges Muslims have encountered over the centuries. However, the lens of Muslim diaspora space highlights the ways in which Aboulela places Sufism at the heart of the novel as a form of meaning-making. Despite the trauma that Oz's arrest inflicts on both Malak and Natasha, Aboulela takes the opportunity to use this moment as a catalyst for their internal jihads, allowing them to follow Imam Shamil's lead. 
Like Lalami in The Moor's Account, Aboulela highlights the relevance of history and the ways in which it can illuminate our understanding of Muslimness in the twentyfirst century. Natasha's deep archival research on Imam Shamil's Sufism, an aspect of Shamil that she has dismissed as irrelevant before, changes the trajectory of her research. At the end, she tells the reader that in a conference paper she "wanted to compare Shamil's defeat and surrender, how he made peace with his enemies, with modern-day Islamic terrorism that promoted suicide bombings instead of accepting in Shamil's words, "that martyrdom is Allah's prerogative to bestow"' (325). Later, she implies that it is not only the focus of her research that has shifted, but the incident has also put Natasha's multiple identities into perspective. She writes:

Yes, it changed me. I might still not have reached home or settled where I belonged, but I was confident that there was a home, there, ahead of me. My homesickness wasn't cured but it was, I was sure, propelling me in the right direction. (328)

This quotation reveals the drastic shift in Natasha's perception of her identity in the aftermath of Oz's arrest, an incident that has opened her eyes to the reality; an incident that has allowed her to observe closely her positionality in the society; one that has introduced her to Malak, Sufism and more importantly to her heritage. Natasha's exploration of her identity then opens onto a reflection on the link between Muslimness and home in the diaspora. At the end, her diasporic subjectivity is recalibrated only when she finds the link, her core, that unites her former self to the new one. With the help of Malak, she is prepared to reclaim the contradictory and paradoxical nature of her core 
that finds its articulation in a diaspora space where the concepts of Muslimness and Britishness are redefined. Through Natasha's rite of passage in the novel, Aboulela thus successfully contests conventional hierarchies that dominate the discourse on Islam and Muslims, foreshadowing the collapse of the dichotomies between inclusion and exclusion as well as us and them in a diaspora space that reveals commonalities and similarities among Muslims and the members of the larger society in the Global North.

\section{Conclusion}

Reading The Moor's Account and The Kindness of Enemies through the lens of Muslim diaspora space demonstrates, despite their differences in style, the areas of productive overlaps between the two writers of Muslim origin. By presenting a complex understanding of diasporic movements and Muslimness, both Lalami and Aboulela problematize rudimentary perceptions of Muslims in the Global North. This reading of the two texts has demonstrated the ways in which Aboulela and Lalami draw on historiography to link the long history of the Eurocentric objectification of Muslims with Muslims' struggles today. As I have attempted to show, The Moor's Account is framed in an older discourse that posits Islam as Christendom's Other, and The Kindness of Enemies delves into the ways in which the age-old Eurocentric discourse on Islam finds its articulations in recent history and in contemporary society. Although the narratives unfold against the backdrop of anti-Muslim discourse in different centuries, the novels do not prioritize it, nor do they necessarily emphasize the historical events themselves, the Narvaez expedition, the Caucasus War, and the War on Terror. Instead, the narratives are 
focalized around the characters' multiple, contradictory subject position that is in a constant state of flux in response to changing diasporic conditions.

The Muslim characters Aboulela and Lalami create and re-create, from Esteban and Imam Shamil to Natasha and Malak are fleshed out as characters whose successes, failures, yearnings, and challenges are relatable human conditions that are amplified within the context of diasporic movement. Moreover, a reading of their transnational and transcultural moves through the mode of Muslim diaspora space highlights that the characters' arrivals in Spain, the New World, Scotland, and Russia are as equally influential in their quest to redefine their Muslim identities as their departures from Azemmur, Dagestan, Sudan, and so forth. The protagonists' diasporic movements do not suggest a geographical return, but as Esteban, Imam Shamil and Natasha's reflections demonstrate, diasporic movements in the novels imply, in Edward Said's words (2004), "a return to oneself, a return to history, so that we understand what exactly happened, why it happened and who we are" (429). This return to one's core, represented as one's Muslim heritage as in the texts, allows Aboulela and Lalami to successfully undo the processes that have perpetually worked to portray the Muslim figure negatively: violent, barbaric, oppressed, exotic, and so forth. Both Lalami and Aboulela thus offer a vision of Islam that moves beyond the clichés that are recycled in its representations towards its intricacy as a lived experience.

In other words and by a way of conclusion to this chapter, The Moor's Account and The Kindness of Enemies successfully reimagine the Muslim figure. Instead of situating their Muslim characters merely within a political context, the novels emphasize 
their multifaceted subject positions through the intricacies of their experiences as Muslims and residents of the Global North. Muslim diaspora space as a framework of analysis then brings to focus how the novels manifestly unsettle the established stereotypes about the Muslim figure and, more broadly, Muslim writing. Instead of using Aboulela and Lalami's level of piety, gender, and citizenship status as a lens, this reading has underscored the ways in which they prioritize the power of imagination and fiction, complicating the Muslim hero in revolutionary ways. 
Chapter 3: Muslimness and The Politics of a Homing Desire: Abu-Jaber, Shafak, and Jarrar

\section{Introduction}

Diana Abu-Jaber's second novel Crescent (2003), considered one of the first Arab American novels27, has received much deserving attention due to its prescient anticipation of anti-Arab sentiments in the 9/11 era. Abu-Jaber had written Crescent well before the attacks - to explore the ramifications of the first Persian Gulf War. In an interview with Robin E. Field, she explains that her motivation in penning the novel was to "convey the richness and the depth of the cultural wealth of Iraq" $(2006 ; 212)$. And she certainly succeeds in portraying the cultural and historical treasures of not only Iraq but also of the Middle East. As literary critics have argued28, the novel follows the tradition of Arabian Nights through the mythical story that the protagonist Sirine's uncle tells; it also reflects the Andalusian cultural imaginary through its references to Islamic poetry, art, and music. However, the novel's publication soon after the launch of the War on Terror shifted the focus to the politics of Crescent.

"People were asking me things like, 'Why do (Arabs) hate us?"” Abu-Jaber states in another interview, "and asking me to speak for the Iraqi nation, which I really didn't want to do and hadn't intended to do in any fashion. It was frustrating to political activists who read it and wanted it to be more staunchly directive in what it says" (Curiel 2004). Some journalists and readers have wanted her writing to interrogate Iraq's “culture of violence" and to portray a more "realistic" image of the nation. Abu-Jaber, however,

27 Along with her debut Arabian Jazz (1993) and Mohja Kahf's The Girl in The Tangerine Scarf(2006). 28 See Gana (2008), Michael (2011) and Laouyene (2015). 
has been more concerned with the creation of versatile, flawed characters than "giving forceful opinions about Hussein's years in power" (Curiel 2004). Her imaginative empathy, without a doubt, is key to her success as a writer who explores the in-between spaces immigrants often occupy. In all her works, including Origin (2007), The Language of Baklava (2007), and Birds of Paradise (2011), Abu-Jaber draws from her own experiences as an Arab American who was born to an Irish-Catholic mother and a Jordanian Muslim father in the U.S. She emphasizes that her position as a writer renders her responsible for creating "as true and multilayered a character experience as I can" $(2006 ; 211)$. Abu-Jaber takes the author's responsibility to create a connection with the reader seriously. As she reinstates in her interviews, this responsibility, however, is more about art rather than politics. "If there's any social agenda in what I do," she explains, it is "trying to counteract the media portrayals-the terrorist for the Arab man and the oppressed, hidden, exotic Arab woman" by "talk[ing] about them in terms of diversity and humanity" and "vulnerability" (2006; 219). Her writing thus has broken new ground in the landscape of transnational American literature, offering intricate portrayals of Arab American characters.

British Turkish writer Elif Shafak, too, stresses the pivotal role that literature can play in challenging dichotomies that perpetuate a perception of differences as threatening. "We can't fight against populist demagogues with only facts and statistics, with reason and logic," she states, "There has to be something else, and that's emotional intelligence" ("52 Insights" 2017). Shafak, who writes in English and Turkish, is the author of eleven novels including The Gaze (2000), The Bastard of Istanbul (2006), The Forty Rules of 
Love (2009), and her recent work 10 Minutes 38 Seconds in This Strange World, which was shortlisted for the 2019 Booker Prize. Like Abu-Jaber, Shafak offers complex portrayals of marginalized characters, including immigrants, Muslims, women, and LGBTQ community, which leads to politically charged readings of her novels. After the publication of The Bastard of Istanbul, for instance, she faced trial— up to three years in prison —in Turkey for having insulted "Turkishness" on the grounds that one of her characters in the novel referred to the mass death of Armenians in 1915 as a genocide 29. The charges were eventually dismissed; however, the trial called into question the Turkish government's commitment to freedom of speech. Shafak remains a controversial, as well as a best-selling name in Turkey. Interestingly, critics in the Global North have not shown much interest in her fiction and its literary aesthetics; she is often interviewed about Turkey's political predicament and her position within it as a writer30. But Shafak's writing, along with her identity eludes categorization. Having lived in Germany, Spain, Turkey Jordan, the U.K, and the U.S., she states that she is deeply attached to:

The Aegean, the other side of the water, so Greek culture is also close to my heart. I am attached to Anatolia—with all its traditions and cultures: Armenian, Sephardic, Alevi, Kurdish, Turkish, Yezidi [...] I embrace them all. to the Balkans $[\ldots]$ to the Middle East—put me next to someone from Lebanon, Iran,

29 Nobel Prize winner Turkish writer Orhan Pamuk faced a similar trial in 2005. He was charged with violating Article 301/2 of the Turkish Penal Code that penalizes "insults" on Turkey, Turkishness, and Turkish government. See TBMM Turk Ceza Kanunu (2004).

30 This could be a consequence of the ambiguity of a literary category-Turkish-American and its lack thereof. Returning to my argument about the racialization of Muslimness in Chapter I, Turkish people as opposed to Arabs are often not considered Muslim, which allows them to pass and avoid discrimination on some level. 
Egypt, Iraq, I have so much to share with them. At the same time, I am a European by birth, by choice, the core values that I uphold. I am a Londoner, a British citizen and despite what Theresa May says, I am a citizen of the world and a global soul. (Mbe 2019)

Although often promoted as a British Turkish writer, Shafak describes herself as a global citizen. Shafak's writing certainly draws from her multifaceted identity, as well as various cultural and traditional influences in a way that transgresses national, religious, and racial boundaries.

In a similar vein, born to a Palestinian father and an Egyptian-Greek mother in Chicago, Randa Jarrar's personal journey across cultures is reflected in her writing, particularly in her debut A Map of Home (2007) and Him, Me, and Muhammed Ali (2016), a collection of short stories that won an American Book Award, a PEN Oakland Award, and a Story Prize Spotlight Award. In 2010, Jarrar was named "one of the most gifted writers of Arab origin under the age of 40" (PEN), which did not come as a surprise to her readers who praised her unique portrayals of disenfranchised characters from queer to Muslim. In 2018, however, she was in the limelight as an Arab Muslim American professor with an "anti-white" and a "pro-hate" propaganda. Immediately after she called Barbara Bush "racist" in a tweet, Fresno State, where she works as a tenured professor, started an investigation; campus-wide protests and public petitions demanding the termination of her appointment ensued. Though Fresno State announced on Twitter that "the university does not have justification to support taking any disciplinary action" against Jarrar (@Fresno_State), she continued to receive harsh criticism from mass 
media, as well as hate mail that had "some sort of racial epithet attached to it $[$...] misogyny, fatphobia, homophobia, xenophobia" (Bell 2019). Following the Barbara Bush incident, several reviews of her books criticized her political comments, conflating her literary aesthetics with a pro-hatred propaganda. On the contrary, however, Jarrar offers a nuanced depiction of identities perpetually relegated to the periphery through a witty, satirical voice. In particular, like Abu-Jaber and Shafak, Jarrar focuses on the intersections of "character" and "geography" in her writing "because of the way I grew up, because I'm a refugee." "I don't have a hometown," she explains, "I don't have a country of origin [...] I have never had the luxury or privilege to feel safe, or secure, or rooted, and I still am able to create homes for myself' (Espinoza 2017). The desire to create and recreate homes is also reflected in her characters' journeys across the borders.

From Home to a Homing Desire: An Analysis of Abu Jaber's Crescent (2003), Shafak's The Saint (2004), and Jarrar's A Map of Home (2007)

Focusing on the intimate link between "arrival" and "departure," Avtar Brah (1996) defines diaspora space as a concept that "places the discourse of 'home' and 'dispersion' in creative tension, inscribing a homing desire while simultaneously critiquing discourses of fixed origins" (192-3, italics in original). Brah's formulation of a homing desire, which she argues, "is not the same thing as desire for a "homeland" (180) challenges the emphasis placed on the politics of ethno-national origins and strong ties to the native country in diaspora studies. The desire to reconstruct home in diaspora space then transgresses the yearning for a return to the place of origin; it is about "the desire to feel at home achieved by physically and symbolically reconstituting spaces which 
provide some kind of ontological security" (Fortier 409). In this sense, diasporic consciousness is in a constant state of flux within the shifting interstices of uprootedness and attachment. Muslim diaspora space as a conceptual category brings to light a literary site in which fixed notions of home, cultural identity, and Muslimness can be coded and decoded in these three novels.

Despite their distinct styles and aesthetics, Abu-Jaber, Shafak, and Jarrar's oeuvre is characterized by a preoccupation with questions of belonging, displacement, and Muslimness. Several excellent studies have analyzed Crescent, drawing attention to the deconstruction of dominant narratives about Arab and Arab American identity in AbuJaber's writing31. Similarly, the small number of articles on Jarrar have studied her representation of Arab Muslim and American identity32. Although Shafak's works, particularly The Bastard of Istanbul, have received critical attention33, little has been written on her debut in English, The Saint of Incipient Insanities. I suggest that re-reading Crescent, The Saint, and A Map of Home contrapuntally through the lens of Muslim diaspora space can offer an even more nuanced understanding of their complex representations of Muslim identity. These novels present multifaceted Muslim characters making connections across ethnic and racial differences, extending the connection among Muslims into the wider society. This reading thus studies the close link between the reconfiguration of the diasporic Muslim self and the desire to feel at home in the diaspora.

31 See Fadda-Conrey (2006), Al-Joulan (2010), and Abdul-Jabbar (2017).

${ }^{32}$ See Albakry and Siler (2012) and Alghaberi (2018).

33 See Simon (2015), Atayurt-Fenge (2017), and Saeed and Zain (2018). 
Focused on immigrant characters from Muslim countries who are caught between cultures, The Saint is concerned with the complexities of diasporic experience, faith, and belonging beyond ethnic and national identities. The novel follows the curious trajectory of Ömer Sipahioğlu who relocates to Boston from Turkey to pursue his doctorate. Ömer's first few days in the U.S. mirror the realities of a newly arrived international student; he strives to find housing, feels a pang of longing for his friends and family at times and is befuddled with the switch to English. Through its protagonist's trials and tribulations in Turkey and the U.S., Shafak masterfully brings together multilayered characters of different backgrounds and origins: two graduate students of Muslim origin, Ömer from Turkey and Abed from Morocco; their roommate Piyu, a devout Catholic Spaniard who dates Alegre, a second generation Mexican American; and Gail, a quirky, queer Jewish American. Ömer's abrupt marriage to Gail who reconstructs her identity every couple of years initiates his long-suppressed meditations on identity and religion.

In her discussion of diaspora space, Avtar Brah (1996) calls into question the emphasis placed on "the traumas of separation and dislocation" in studies on diaspora communities. Displacement is certainly an integral part of the diasporic experience, but she adds that diasporas are also "the sites of hope and new beginnings" (193). For Avtar Brah, diasporic consciousness oscillates between the tension of home and dispersion and loss and hope, inscribing a homing desire that emerges within the interstices of stability and mobility. The complexity of affiliation for diasporic subjects is reflected in Ömer's vacillation between excitement and sheer terror during his journey. His ontological struggle is emblematically triggered on the transcontinental flight from Istanbul to 
Boston. Ömer finds himself wallowing complexity: "what was he doing, where was he going, why was he leaving his country, what difference would it make to have a Ph.D. in political science in America" (SII 77). However, his reflection soon gives way to "a set of uplifting decisions" about being more mindful, studious, and confident in Boston, substituting his anxieties with a desire to rebuild himself. This shift in perspective occurs precisely "somewhere above the Atlantic Ocean," (77) which serves as a cogent symbol of what Homi Bhabha (2004) calls, "the realm of the beyond," where the established dichotomies between centrality and peripherality are suspended eventually to be replaced and recreated within the "interstitial passage between fixed identifications" which creates "a cultural hybridity that entertains difference without an assumed or imposed hierarchy" (5). "The Atlantic Ocean" as a representation of deterritorialized spaces occupied by immigrants foreshadows the theme of a homing desire that emerges in a transnational juncture throughout the span of the novel. In particular, the lens of Muslim diaspora space brings to focus the ways in which its Muslim characters Ömer and Abed recognize not only the importance of a point of origin but also of connections beyond ethnic, national, and sectarian identities in the spaces of inhabitance they call "home."

At first, Ömer's homing desire does not stipulate a point of origin, as he seeks to erase his Muslimness as well as his Turkishness through "the privileged pleasure of being a nobody" in a foreign nation (SII 52). Once he settles in Boston, however, he vacillates between affirming and negating his Turkish Muslim diasporic identity. The difficult process of "arriving" and integrating to a new culture and language, along with the stereotypes against which he and his roommates battle (SII 111) reminds him of his 
indelible foreignness as a Muslim and a Middle Easterner. What emerges out of this identity affirming and negating dichotomy is a discernible sense of loss illustrated by Ömer's relation to the umlaut on his name. As he drunkenly tells Abed one night, he will "put the dots of my name back to their place"; "Back in Turkey he used to be Ömer Sipahioğlu [...] here in America he had become an Omar Sipahioglu" (SII 5), referring to the more common Arab version of his name. As the suggestive title of his dissertation indicates, "Blood, Brain and Belonging: Nationalism and the Intellectuals in the Middle East" (SII 218), Ömer's attempts to debunk the paradigm of identity is futile. In a conversation with Abed and Piyu painted with "this common shade named The Difficulty of Being a Non-American in America" (SII 108, italics in original), he states "When you are a foreigner, you can't be your humble self anymore. I am my nation, my place of birth. I am everything except me" (SII 110). Ömer's reflection points to the complex ways in which the tension between home and dispersion inscribes a homing desire that does not necessarily imply a yearning for the homeland. If a homing desire is "centrally about our political and personal struggles over the regulation of belonging" (Brah 192), Ömer's relationship to Muslimness and Turkishness in the U.S. is mediated by his socially, politically, and historically specific lived realities.

The dialectical relationship between his seemingly oppositional yet interlinked states points towards an atemporal circularity in the passage of instertiality, which is made conceivable by the framing of time in a non-linear, ubiquitous fashion in the novel. Ömer's discontent with the conventional time measurement system urges him to develop his own circular system, which allows him to measure time by playing his favorite songs 
on a loop. His resistance to the fragmented notion of time is fortified by the movement of time in a circle at the macro-level throughout the novel: "At 5:30 pm in Boston, 10:30 pm in Marrakech, 11:30 pm in Madrid, 12:30 am [...] Allegre arrived at the party house" (118), or "By 11:33 pm in Boston, 4:33 am in Marrakech, 5:33 am in Madrid, and 6:33 am in Istanbul, she decided..." (122). For instance, the chapter "Winter" takes the reader to Istanbul "at 11: 33 a.m.," when a group of young protestors gather and start shouting in front of Sultanahmet Mosque. At 11: 35 a.m., the police squad approaches to the square. The narrator depicts what follows:

At 11:36 a.m., a sinewy police officer [...] drew a roundish shape in the air with his club and started walking toward the rabble, as if that circle would be the very gate from which he'd enter into the scene [...] Exactly at the same moment, an agile photographer working for Reuters, finally satisfied with the luminosity and clarity of the frame he had obtained, focused his camera and started shooting [...] The Reuters photographer held his breath, pleased with the fineness of the pictures, and took the roll out to replace it with a new one. That lasted eight seconds.

Within those eight seconds, Zahra back in her house in Marrakesh poured melted lead into a pan of cold water to protect the apple of her eye again against the evil eye $[\ldots]$ When the camera had paused clicking in Istanbul, the lead stopped sizzling in Marrakesh, and the coyote gulped down the Arizona, the clock in Harvard Square moved from 3:37 a.m. 3:38 a.m. That was precisely when winter came to Boston. (204-5) 
Shafak destabilizes the notions of precision and accuracy instead of specifying the exact time of an incident to convey the constant state of flux in which her characters take shape. Opening some of the chapters in this fashion also allows her to bring different characters, as well as different localities together. The cyclical perception of time disrupts, in Shafak's words, the idea that time has to "flow in a line, in a progressive line where the past, the present, and the future have a neat order of their own" (MacDonald 2005). The constant disruption of linearity provides the backdrop for the deconstruction of traditional formulations of home in the novel, emphasizing the characters' homing desires instead. An analysis of the process of homing desire through the lens of Muslim diaspora space further reveals how Muslimness becomes intertwined with the theme of displacement and belonging in the novel.

Shafak places Ömer and Abed's Muslim identity at the heart of their homing desires, as she brings forth interaction among Muslims, and interactions between Muslims and the wider society, as illustrated by Ömer and Abed's friendship and their connection with Piyu, Alegre, and Gail. In Brah's formulation (1996), a homing desire emerges in a diaspora space where "the configurations of power that differentiate diasporas internally" also "situate them in relation to one another" (209). As discussed in Chapter 1, a diaspora space that is specifically Muslim shifts the focus from the dichotomies between the majority and the minority, as well as the secular and the religious towards a contact zone that is marked by diversity, multi-axial locationality, and dynamic interaction. Shafak, for instance, draws on the conflict between the secular and the religious that dominates contemporary debates on Islam to highlight its totalizing 
tendencies. The juxtaposition of Ömer, a "lapsed" Muslim, and Abed whom Ömer defines as, "a spider-headed Muslim" (SII 13) underpins the levity of the narrative while allowing Shafak to attend to the inimical nature of these terms. Ömer explains that spider-headed is "the Turkish expression for people like you [ ...] long-behind-the-times, conservative, old-style, traditionalist" (13). Befuddled, Abed retorts, “That means pious in my book. I am a pious Muslim whereas you are a lost one" (14). Such exchanges between Ömer and Abed — at the beginning — is crucial within the context of Muslim diaspora space, for it provides a springboard through which the text initiates its deconstruction of the static modes of understanding Muslimness.

As the narrative delves deeper into the intersecting diasporic experiences of Ömer and Abed, the drastic shift in the characters' perception of "conservative" and "lost" is amplified. Although Ömer remains a "lapsed" Muslim throughout the novel, he recognizes that he is indeed a traditionalist at times (SII 108). In a similar vein, Abed ceases to assert the hegemony of a pious self as "true Muslimness" as he does the difficult work of negotiating his accountability to Islamic norms and ideals (342). Ömer's drinking habits do not render him blasphemous, for he will always remain Abed's "Muslim brother" (148); likewise, Abed's decision to sexually experiment does not make him "not- Muslim-enough" (348). As Abed tells Ömer when his mother, during her visit, insists to sacrifice a ram in Boston, "Omar [sic], my brother. You should help me. No matter what, you are a Muslim, right?” (198). Despite his agnosticism, Ömer is indeed a Muslim, as the narrator emphasizes his Muslim cultural identity with the phrase "a born Muslim" (11). Ömer and Abed's subsequent adventures highlight not only the solidarity 
between the two characters as diasporic Muslims, but it also foreshadows the ways they redefine the meaning of Muslimness, challenging the mainstream perception of Islam. Ömer's nominal Muslimness, for instance, is heightened in the diaspora, becoming a constitutive part of his identity. As exemplified in the slaughter episode, Ömer and Abed redefine halal and haram (SII 199). Such a reconfiguration may challenge traditional formulations of Islam by interaction with realities in diaspora spaces through "the lived experience of locality" (Brah 192). Despite the agonizing machinations of diasporic experience, the characters begin to reconstruct a new sense of being at home within the interstices of uprootedness and attachment, Muslimness as religion and a lived reality. The instability of migratory movement in this context opens up the space, in Homi Bhabha's words (1992) the "rim of an inbetween reality" (148) in which they can redefine Islamic norms as it relates to their homing desires. Muslimness as a living reality rather than a prescriptive belief system inscribes a point of origin which enables Ömer and Abed to "celebrate a beginning which adds to and fertilizes further multiple points of other displacements" (Al Deek 20). However, it is not until the end when Gail commits suicide in Istanbul that Shafak's characters begin to perceive their displacement(s) as the fertile ground for new modes of being and belonging.

As Özlem Ö. Yazıcıŏlu (2009) argues, Gail’s suicidal attitude in the novel "recalls the eternally displaced Jew" (61). Perennially locked in the absence of a place of origin and a family, Gail is paradoxically fixed within the paradigm of instertiality. Gail "free-floats and claims no historical specificity, belonging everywhere by virtue of belonging nowhere" (Al Deek 21). The last chapter takes us to the Bosporus Bridge in 
Istanbul located in between "the east" and "the west" - a signifier of the liminal spaces in which most migrants find themselves. Gail's desire for "the inbetween" is emphasized as they pass the bridge, and Gail thinks to herself, "this inbetweendom was the right place, and this very moment was the right time to die" (SII 347). The narrative then shifts to her husband Ömer and their friends to mark the very moment they all simultaneously negotiate uprootedness and attachment. As tragic as it is, Gail's suicide - an attempt to occupy the-in-between-spaces - paradoxically emerges as a celebration of a beginning for Ömer and Abed. During Gail's fall from the bridge, we are offered a glimpse into a new beginning for Abed. For the first time, he breaks away from Islamic ideals as prescribed in religious texts when he returns to be with a love interest at the laundromat, while simultaneously undergoing "a subtle loosening of the moorings that tied him into his homeland" (SII 348). The narrator explains, "Not that he felt less connected to his life in Morocco now. But somehow he felt more connected to his life in the United States" (348). In this context, the diasporic experience does not inscribe his homing desire through "a wish to return to a "place of origin"” (Brah 193) or to a pure form of Islam. Instead, Abed's homing desire is constituted through his acceptance of his multiple positionalities as a Muslim Moroccan man living in Boston; neither his Muslimness nor his Moroccan identity is erased in this process. He thus transgresses the confines of locality and scripture, as his identity as Muslim Moroccan is expanded towards transnational levels of signification within the context of Muslim diaspora space.

Similarly, Ömer's travels between Boston and Turkey become a rite of passage towards self-realization, serving as a meditation on the complex processes of cultural 
identity formation. As he watches Gail on the bridge, "a fleeting consolation crosses [his] mind. She won't die [...] People do not commit suicide on other people's soil, and this is not her homeland" (SII 359). "But did she ever have one?" the narrator interjects, "Who is the real stranger - the one who lives in a foreign land and knows he belongs elsewhere or the one who lives the life of a foreigner in her native land and has nowhere else to belong" (350-51). The traumatic incident that unfolds in his native country reveals to Ömer that the oscillation between multiple identities and conflicting loyalties does involve estrangement and loss but also creativity and integration, newness and tradition. Although he feels detached from Turkey occasionally, Ömer recognizes his Turkishness and his Muslim heritage as his point of origin, which, as opposed to a free-floating movement registers an orientation, a starting point, "an identity's history, its gravitating 'somewhere,' as well as its simultaneous undergoing of transformation, its multiple metamorphoses" (Al Deek 27). As Ömer and Abed reject fixed definitions of identity, ethnicity, and religion in the novel, the diasporic connections they cultivate enable them to celebrate not only their shifting subjectivities but also the "Eastern ethos" (SII 108) around which they were raised. Ömer and Abed's deepening connection across their differences forms an essential part of their homing desires, symbolizing the vast possibilities that can arise in a diaspora space. In this sense, they are analogous to "birds of migration" that "initially detached from their own flocks to migrate to faraway lands," and "once there, they flocked into detachments" (SII 81). "Flocking into detachments" in this context points to new sites of belonging, "the spaces in between difference" (Friedman 1998) that emphasize the visibility of sameness rather than differences among 
Muslim communities, and by extension among other diasporic groups, as well as local populations.

For instance, the house that Ömer, Abed, Piyu, along with Alegre and Gail, inhabit aptly symbolizes the diasporic space of encounter where the secular-religious and Islam-Christian binaries are contested. The juxtaposition of Zahra's superstitious rituals, Abed's Holy Koran, "his leather amulet against the evil eye," with Piyu's "New Jerusalem Bible, a grazed porcelain Jesus carrying the cross, Blue Madonna nightlight, a sixteen-by-twenty Guardian Angel frame" (172) signifies the ways in which invisible boundaries can be deconstructed:

The thought of the possible objections or questions a Catholic might raise against Islam had crossed Abed's mind several times, and he had in store more than few answers, in case Piyu ever used them. Likewise, Piyu, too, had pondered the likely arguments that a Muslim could make against Christianity and had his answers ready. In the fullness of time, it had become clear that none of these answers would be needed, as both Abed and Piyu had been remarkably respectful toward each other's religion. (288)

The narrator emphasizes the harmony, peace, and understanding that the characters cultivate in the house. In another scene, intercultural dialogue at the juncture of cultural encounters is extended to a multinational context at a Japanese Chinese restaurant. Alegre's curiosity about the holy month of Ramadan generates a utopian harmony at the dinner table as Abed discusses its significance and the dishes cooked throughout the month. Piyu then goes on to give resonating examples from Catholicism, and "a breeze of 
geniality canopied the table," as the narrator explains, "now garnished with six different dishes six distinct soups, a breeze tenderly ferrying them from the Muslim concept of sabr to the verb aguantar in Spanish (143-44, italics in original), both of which connote endurance and perseverance in the face of suffering. Ömer and Abed's connection with one another, as well as with their American and immigrant friends points to an embrace of differences without an assumed hierarchy.

Abu Jaber's Crescent delves deeper into the spaces in-between-difference occupied by Muslim characters in the diaspora. Like The Saint, Muslimness provides the subtext within which Crescent operates its leitmotif: displacement, cross-cultural connections, and homing desire. The novel chronicles the intertwined stories of Han, an Iraqi professor of Islamic history and Arabic literature at UCLA, and Sirine, a secondgeneration Iraqi American chef. Forced to leave Iraq due to his political publications against Saddam Hussein, Han grapples with the irrevocable loss of his home and family. He meets Sirine at Nadia's Café, a Lebanese restaurant in Irangeles, where she starts working after a long career in French, Italian, and L.A. restaurants. As Han helps Sirine reclaim her Muslim Iraqi heritage, and Sirine introduces him to American culture, the notions of Muslimness become intimately linked to the protagonists' homing desires on their journey.

Susan Friedman (1998) argues that the overemphasis placed on ethno-national and cultural difference in diaspora studies obfuscates "interactive mediations between difference, the blending as well as clashing that takes places in the contact zones between difference" (68). She thus shifts the theoretical focus to the spaces in between difference, 
"the dialogic between sameness and difference, between mimesis and alterity" (103).

Like Brah, Friedman emphasizes contradiction as a crucible to the formation of diasporic subjectivity. Re-reading Han and Sirine's love story through the lens of Muslim diaspora space points at the ways the novel privileges experiences of a homing desire in the diaspora over an ethnic, national, and sectarian kinship. Muslim diaspora space in the novel emerges as a paradoxical space of possibilities, which allows for new expressions of home and Muslimness.

Nadia's café, the main setting of the novel, serves as a cogent metaphor of such spaces-in-between-difference. As "a little flavor of home" (Crescent 22) for the students and immigrants from the Middle East, the café registers a profound shift from the dominant discourse on extremism, religiosity, and nationality towards Muslimness as an episteme that is ambivalent, diverse, and cultural. The names of its regulars from Egypt and Kuwait—Schmaal, Jenoob, Shark, and Gharb — mean, respectively, North, South, East, and West (Fadda-Conrey 195). This foreshadows its importance as a space of encounter where differences are reconciled, highlighting the multifaced nature of Middle Eastern identity. The plot unfolds against the backdrop of the Iraqi war, and the novel's references to Islamophobic rhetoric are subtle yet powerful. "Sometimes Sirine used to scan the room and imagine the word terrorist," the narrator states, "but all that came back to her were words like lonely, and young" and "infinitely vulnerable and tender" (22). In another scene, Abu-Jaber contests the negative representations of Muslim women that simplify their lived experiences. 
When Sirine meets Han's Saudi American student Rana, the first veiled Muslim woman with whom she interacts, Sirine assumes her to be passive and conservative as "a young woman" whose "head is covered with a black veil, only her face showing" (32). Later, Rana invites Sirine to a "Women in Islam" meeting in downtown L.A. At the gathering, Sirine is introduced to a diverse group of Muslim women some of whom are "fully cloaked in veils and floor-length black dress; the rest...dressed in pants and cardigans, jeans and blouses" (188); some have "fair skin, light eyes, including some of the covered woman. Some are in white head scarves and some in black, and each scarf seems to be knotted or fastened in a slightly different way" (190). As her friendship with Rana deepens, Sirine realizes that Rana's scarf is an integral part of her identity rather than a tool of oppression. Initially, Rana's independence, intellectual and sexual curiosity, as well as her connection to Islam is obfuscated by the piece of fabric that she chooses to wear. This is best illustrated in a scene later when Rana tells Sirine about her sexual partners. Confused, Sirine asks her why she still wears the headscarf. "This reminds me that I belong to myself," Rana responds, “And to God. I still have faith, you know” (318). As Sirine observes the ways in which Rana re-defines Islam in her terms, she recognizes Rana's decision to wear the headscarf as a means of empowerment.

While the novel sets forth the cultural and geographical diversity of its Muslim and Middle Eastern characters, its emphasis is on the ways in which they reconcile their ethno-national and religious differences. In this spirit, the cafe's portrayal evokes a sense of home, with its "little TV permanently tuned to the all-Arabic station, with news from Qatar [...] Kuwait, endless Egyptian movies, Bedouin soap operas in Arabic, and 
American soap operas with Arabic subtitles" (Crescent 22-3); with stacks of textbooks and newspapers "from home [...] Algeria, Bethlehem, Baghdad" (195-6). Through its occupants' diverse backgrounds-Middle Easterners, Muslims, Christians, the Mexican chef Victor Hernandez and local Americans alike- Nadia's café provides the context that allows Muslim Middle Eastern characters to relate to one another as well as to the larger community.

In this spirit, Crescent draws on Muslimness as a cultural and spiritual signifier, with its characters reclaiming Islam as a powerful symbol of the Muslim Middle Eastern cultural ethos. For instance, despite the café's owner Um-Nadia's agnosticism and the large number of Christian customers, there are special menus and celebrations at Nadia's at both Christmas and Ramadan—-because "they all like to eat the traditional foods prepared throughout the Middle East to celebrate the nightly fast-breaking during Ramadan" (Crescent 273). The cafe is resignified as a diaspora space that is highlighted by Muslim and Christian rituals when "Muslims all over town [...] loiter[ing] outside and waiting for tables, Iranians, Saudis, Palestinians, Lebanese, even Malaysians, Pakistanis, and Croatians ( 297) during Ramadan; and the next day, the cafe is lit with string Christmas lights (280). By highlighting "the idea of Islam as a way of identification" for both Christians and Muslims (2006; 220), Abu-Jaber calls into question dichotomies that propagate a single, religious vision of Islam. It is against this background that Sirine and Han's subjectivities undergo consistent transformation in the processes of meaning making, interaction, and expression. 
Through Han and Sirine's quest for home, Abu-Jaber further maps the intersections of Muslimness, which evokes memories of home, and diasporic spaces as they are articulated in terms of a homing desire. Han's agonizing distance from home prompts Sirine to revisit her own memories - the absence of her parents, her forgotten ties to Iraq, and her Islamic heritage. On one occasion, Han meditates on the difficulty of grasping "the thought of never returning" (Crescent 68). His reflection strikes a chord with Sirine who later tells him, "I guess I'm always looking for my home, a little bit. Even though I live here, I have this feeling that my real home is somewhere else somehow" (132). As Han delineates the life he left behind - the vivid streets of Iraq, the picturesque mountains, the chaotic souk—Sirine recalls the painful memories of her parents' continuous move around the globe as American Red Cross employees and their death in Africa. The narrator states:

She and Han stay up late in the evenings talking [...] and try to tell each other, in bits and pieces, who they are and where they come from. Han tells her about the foods they ate in Iraq, the clothes they wore, the animals and plants and winds and rocks of his home $[\ldots]$ Then Sirine tries to conjure up her childhood in Los Angeles for him with a similar flux of minor detail: the smell of her classroom, her wool skirts and knee socks, the way she wore her hair in braids, barrettes, ponytails. (138)

Han thus inspires Sirine to explore her familial and cultural ties while she offers Han a multifarious image of American and Arab American culture. Even though Han initially retains a firm connection to his homeland, his identity takes on "a cultural turn" (Hall 
2001), a rerouting of identity that moves beyond the dream for a homeward journey towards a homing desire.

His longing to feel at home is instantiated as he seeks to bridge the emotional and cultural gap between Sirine and himself, which in turn helps him transgress the barriers between himself and American society on a larger scale. On days off, they explore the city, "unknown neighborhoods, the distant far-flung suburbs and adjacent towns; [...] the garment district, down streets crowded with dense Mexican candies, pastel-colored Korean candies, Chinese medicinal herbs, Japanese ointments" (Crescent 208). On such a day at the beach, as Han tells Sirine about the Iraqi town in which he grew up, he pauses and says: "For a moment, I forgot that this was America. I was on the banks of the Tigris. I could see the sun through my eyelids. My sister was about to call me in to eat. I haven't forgotten any of it [...] I've met you—it's starting to return. I'm beginning to feel it and see it" (210-11). Han articulates his diasporic existence through absences—of the sight, taste, and memory of Iraq — until he meets Sirine. His journey back to Sirine and California at the end of the novel, after his sudden return to Iraq to tend to his sick mother, points at a shift from his perception of home-as-homeland towards a homing desire detached from the spatial concept of location. Han's "home coming" at the end signifies his reconfiguration of home within "the motions of journeying between homes, of hailing ghosts from the past, of leaving and staying put, of continual reprocessing of what home is/was/maybe" (Fortier 402). Since Islam is "what shaped [his] character and mind and gave [him] hope for the future" (Crescent 177), his homing desire also involves a constant transformation of what Muslimness is/was/maybe. Al Deek (2016) argues that 
"a translated cultural identity is one that does not totally break from the past" (58) but rather is rerouted at the site of intercultural encounter. As Han's cultural identity undergoes a cultural translation, his Muslimness emerges as the bind that ties him to his place of origin.

In a key episode, Sirine curiously asks Han about Islam during dinner "after another glass of wine" (Crescent 80). In response, Han elucidates the interior of mosques, recites the azan and demonstrates the genuflections for daily prayers as an inebriated Sirine joins him. The contradictory references - two opposite sexes drinking wine, getting intimate, and praying_ overtly challenge traditional prescriptions of Islam. Moreover, this scene demonstrates that Han's displacement(s) allow him to articulate new modes of Muslimness as he moves across borders. Every time his "old way of being" is translated into new contexts, so is the normative way of being a Muslim. "I haven't prayed in some time," he tells Sirine, "I'm out of practice" (80). Having read a letter sent to Han from Iraq that discussed his strict adherence to Islamic principles, Sirine finds his statement intriguing. When she asks him later whether he believes "your religion defines who you are," he stresses the complexities of affiliation for a diasporic subject. "I'm no longer a believer,” he says, "but I still consider myself a Muslim. In some ways, my religion is even more important to me because of that" (182). Han's emphasis on the importance of his religion despite his agnosticism is crucial within the context of Muslim diaspora space, for he offers an alternative vision of Muslimness.

He no longer subscribes to any one of the scholastic, philosophical, or theological approaches evoked by the concept of Islam; instead, he engages with a combination of 
various registers to generate meaning of his diasporic self through, what Shahab Ahmed (2015) calls "unifying contradictions of Islam" (506). "The fact of exile," Han stresses, "is bigger than everything else in my life" (183). He does so by clicking his prayer beads, which represents his desire to establish a series of connections between his Muslim and diasporic identity. Moreover, Sirine's quest for exploring her long-forgotten Muslim identity through her visit to a Sufi dervish meeting (Crescent 264) and her participation in the "Women in Islam" meeting (186) underscores Muslimness as a process of meaningmaking for both characters. Han reconfigures what it means to be a Muslim in a new setting in the absence of Islamic signifiers such as the call to prayer and the sight of minarets, all of which remind him of home. Like Ömer and Abed, Han's homing desire then does not imply a geographical return but suggests in Edward Said's words (200-) "a return to oneself, a return to history, so that we understand what exactly happened, why it happened and who we are" (22). With the help of Sirine, he reclaims the contradictory and paradoxical nature of his identity that finds its articulation in a diaspora space where the concepts of Muslimness and Americanness are redefined.

In A Map of Home, Jarrar is concerned with the same idea of a return to one's history and heritage as one recreates home in diaspora. Crescent and The Saint point at precisely their characters' desire to rebuild home in-spaces-in-between-difference. At the end of both novels, we are offered a glimpse into the potential ways in which the protagonists will negotiate their multiple identities. Similarly, A Map of Home explores its protagonist Nidali's experiences as a transmigrant; however, the novel also chronicles how exactly ideological expectations and resistance collide. As opposed to Crescent and 
The Saint and their omniscient third person narrators, A Map of Home presents a firstperson narrator who against all odds achieves to become a writer at the end. Literary critic Susheila Nasta writes that diaspora "does not only create an unrequited desire for a lost homeland, but also a 'homing desire,' a desire to reinvent and rewrite home as much as a desire to come to terms with [it]" (7). In this spirit, the novel allows its protagonist to not only reconstruct the notions of home and Muslimness but also rewrite it in her memoir — the novel that we are reading.

A Map of Home traces Nidali's rites of passage as she moves across borders, from Boston, Kuwait, Palestine, and Egypt to Texas. Born into an Egyptian-Greek mother and a Palestinian father in exile as an American citizen, Nidali's cross-cultural experiences destabilize the fixed notions of home as suggestively pointed out by the title of the novel: "a map of home" or its lack thereof. The novel unfolds against the backdrop of the ArabIsraeli conflict and the Gulf War, and the condition of displacement is envisaged as a genealogical inheritance inflicted on the family's lineage. "I thought about all the main events of my family history," Nidali writes, "and discovered that they were all wars" (195). From the beginning, the novel brings to light Nidali's efforts to grasp the striking contrast between her culturally diverse family and community, and the difficulty of crossing borders. Her circle of friends comprises of "Sunnis, Shia's, Christians, Hindus, and Mai whose parents were communists" (51). Young Nidali discusses the reconciliation of such differences: "I like that Linda and I could be different but still believe in so many similar stories" referring to the biblical stories that also permeate the Koran (20). As illustrated by the juxtaposition of her Greek-Egyptian grandmother's 
tombstone embellished with cross with her grandfather's commitment to praying five times a day, her close family, too, embodies a powerful example of harmony and coexistence. Nidali's conversations about God and "the truth" with her mother are telling in this context. In a key episode where Nidali and her mother sit on a beach by the Gulf that oversees Iran, Nidali asks:

“Linda says God has a son. Isn’t that crazy?” I said. Mama turned and looked at the Gulf. She took a deep breath, then, "Some people believe that. Your yia yia believed it. She was a Christian."

"But is it true?"

"Habibti, the truth is, different people believe different things [...] For example, some people..." and she pointed across the water, to the hills of Iran, "think that God exists in fire. Some people believe God had a son. And some people believe that after we die, we will be reformed into other beings." (19)

This episode offers a glimpse into the arduous process that Nidali undergoes as an adolescent, as she comes to terms with the paradoxical nature of home, borders, and religion. The binarisms that enigmatically affect Nidali's upbringing are further symbolized by the water metaphor that is contrasted with the reality of rigid territorial boundaries. In the same episode, Nidali goes on to ask her mother:

"Do you think people can be re-formed?"

"Possibly," she said, "Take the waves in the water at our feet. They aren't the same thousand waves, but they aren't completely different. Maybe people are like those waves, made of the same ocean of souls." (19) 
The cultural and religious hybridity that Nidali strives to conceptualize contradicts her reality, in which border crossings suggest long waits and hostile treatment.

When Nidali and her family are compelled to visit the West Bank to bury her grandfather, it takes them days to complete their journey. "On the airplane, I took out a map from the pocket in the seat in front of me, and on it, Palestine was the country stuck to Egypt," Nidali writes, "so I asked Baba, "Why can’t we just drive there, or take a plane straight there? He told me to be quiet and fasten my seatbelt" ( $A$ Map 95). Entering Palestine from Kuwait requires "a flight to Jordan," "drive to El-Daffa," to "the bank," and crossing the Allenby Bridge Israeli checkpoint (95). The inspection on the bridge points to the ways in which visitors are further dehumanized; they are asked to strip off and spend the night waiting at the checkpoint. "I was afraid and tired," Nidali recalls her experience, "and I didn't understand why we had just been treated so poorly for so long" (101). As opposed to the Bosporus Bridge that symbolizes in-betweendom in The Saint, passing through the Allenby Bridge in A Map reveals the way in which a bridge, usually a symbol of connection, paradoxically serves as a barrier between the two nations who share the same land, history, and culture.

Unlike her parents, Nidali resists the physical, cultural, and political barriers by embracing "home" as an epistemological quandary couched in the notion of unbelonging. For instance, her father, who is not allowed to return to his village after the War of 1967, is attached to the idea of home-as-homeland as opposed to her mother, who was so rooted that "she had been born and brought up in the same apartment" ( $A$ Map 37). Her father's dispersal from his homeland further ignites an agonizing grief and 
longing in him and shapes his volatile predisposition. His pain of homelessness is poignantly reflected in the instability of his relationship with his family as he vacillates between displaying affection and utmost care and physically abusing his wife and children. His ambivalence, bolstered through his sincere denial of domestic violence (132), is problematized as a byproduct of bereavement and war. Nidali writes: Baba said that moving was part of being Palestinian. "Our people carry the homeland in their souls," he would tell me at night as he tucked me in. This was my bedtime story when I was three, four. "You can go wherever you want, but you'll always have it in your heart." I'd think to myself: "That's such a heavy thing to carry." (9)

As a second-generation Palestinian who has no recollection of her birthplace, America, Nidali is cognizant of the geopolitical realities that have dictated her life, leading to her "feeling splintered, like the end of a snapped off tree branch" (231). During her visit to Palestine, her grandmother tells her a story about "the half-and-half boy who was half a human" and "I wondered," she writes, "if she told me this because she thought I was a half girl since I'm only half Palestinian." Her grandmother, however, reassures her that "a half-and-half one" means "stronger and better" (104). Despite confusion, ceaseless questions, and challenges, Nidali does internalize Sitto's narrative, as she writers elsewhere, "When I'd tricked my mind, it would float away, and I could see that I am just. I'd see myself from outside my own mind: my life, my body, and I was not half something and half another, I was one whole, a circle" (59). Her profound sense of loss 
thus gives way to a celebration of border erasures as a liberating act as she moves across continents.

This is best illustrated in a scene in Alexandria, Egypt, following Iraq's unprecedented attack on Kuwait. Nidali draws a map of Palestine from memory to enliven her father's spirits. She asks her father if she drew it right. However, her father's response, "who knows?" befuddles her: "What do you mean, Baba, when you say 'who knows'?" Her father, who is disheartened to have left home once again, tells her, "I mean...there's no telling. There's no telling where home starts and where it ends" ( $A$ Map 193). The ambivalence is a source of perpetual pain for her father whereas Nidali perceives it as a form of empowerment. Later that day, she returns to her room and intentionally erases the borders on the map. "I erased the western border, the northern border," she writes, "I erased the southern and eastern border" (193). Her figurative and literal erasure of borderlines reflects the political discourse of the novel, foregrounding the elasticity of Palestinian borders that are continually shaped and reshaped. She continues:

I surveyed what remained: a blank page, save for the Galilee. I stared at the whiteness of the paper's edges for a long, long time. The whiteness of the page blended with the whiteness of my sheets. "You're here," I thought as I looked at the page and all around me. And oddly I felt free. (193)

The remapping of the borders generates a constant state of instability, consequently shifting realities for its displaced subjects. Unlike her parents, however, Nidali's identity is re-constituted through a figurative eradication of borders, which transmutes the 
exigencies of diaspora into a celebration of her multifaceted identity as a creative force. Her construction of the memoir further allows her to demonstrate, in Fanon's famous words (1986), that “in the world in which I travel, I am endlessly creating myself" (231). Fundamental in this regard is Nidali's articulation of Muslimness as an anchor within the thematic framework of perpetual movement which drives the narrative.

Shahab Ahmed (2015) reconceptualizes Islam as a phenomenon "whereby and wherein truth and meaning are constituted and distributed in particular ways and are not adequately captured or apprehended by the concept of religion" (197). When religion rather than truth or meaning is the primary lens through which we understand Muslimness, he posits, we tend to overlook "central ways in which Muslims have conceptualized being Muslim” (201). As Jarrar explores Nidali’s life, she offers a mode of Muslimness that fluctuates and evolves through intercultural exchange(s) and displacement(s), prioritizing the broad spectrum of expressions and beliefs of Muslims as opposed to Islam as a set of restrictive principles. For instance, the chapter "Comfort" titled after the Sura Al-Sharh in the Koran traces Nidali's preparation for a Koran recital competition at a school in Egypt. For Nidali who still "couldn't wrap her mind around the idea of a larger God, of souls, or infinite space, or religion," (A Map 39) the Koran contest serves as an opportunity to find answers to her questions about "Linda's Jesus, my Muhammed, Sherif the barber's Marx" (39) and "to understand God" ( 40).

In this chapter, Nidali develops her own understanding of Islam, liberated from political ideologies and personal agendas. For instance, as the school prepares for the contest, her teacher reminds her to "cover [her] hair" (A Map 48). "My friend Riham was 
in the contest too, but her hair was already covered," Nidali recalls, "her father was from Yemen and told her she had to." As opposed to her friend's father, Nidali's Baba "would never let me cover my hair" (49). In fact, her father tells Nidali to not "even consider it":

Forget those retarted idiots! You must be cleansed to read the Koran, but no one said you had to be covered. Esam [her cousin who was visiting] coughed from his post in the corner of the living room. "Pardon me, uncle, he said. "But this talk is incorrect. God has decreed that women cover themselves."

“Pardon me, 'Amo," Baba said, "but shut up." (49)

However, Nidali's father's secularity, his love of whiskey (69), and disapproval of the headscarf do not deflate the significance of the Koran for him (50). Just as he makes meaning of his Muslimness based on his lived experiences, we are offered a glimpse into the formation of Nidali's Muslim subjectivity when she attends the contest. By showing up with her hair covered, she indeed "was disobeying my father" (50), but she challenges her father's experience of Islam in her own way. As opposed to her friend Riham wearing "a white headscarf, a long dress, a shirt, and gloves," Nidali covers her hair "in Mama's handkerchief" and wears "calf-length skirt fastened around my hips so I could stretch it down to my ankles" (50). She wins the contest because of her heartfelt recitation of the Koran; her victory thus symbolically unsettles the hegemony of prescriptive Islam and questions the authority of the external over internal dimensions.

Nidali's perception of Islam is further juxtaposed with her cousin Esam's strict religiosity ( $A$ Map 46). The moment when he tears off Nidali's Wonder Woman stickers during his visit because she was "a shameless prostitute" (53) marks a threshold for 
Nidali as an eight-year-old. In the image of "Woman of Wonder" (41), Nidali seeks to find herself, "her wavy black hair, so black it was almost blue: black like Mama's hair, wavy like mine, ...the eagle on her top, resemb[ling] the eagle on the Egyptian flag, ...her lasso remind[ing] me of the rope women in Palestine tie on buckets and around goats' necks":

I searched for hair on her arms but they were smooth. And when I saw the stars on her shorts, I was reminded of my blue passport, of how I was born in America. I wondered if Wonder Woman was Egyptian and Palestinian and American, like me. (42)

Nidali uses her imagination to project the multifariousness of her identity onto the image on the stickers. However, the restrictive sociopolitical, ideological constructions contradict her reflection. Initially, she thinks it is God who "had come in and peeled" her stickers (52) because of the amount of skin shown on the picture. Thus, when she finds out that it is her conservative cousin, her connection to God is restored. Despite her frustration, Nidali chooses not to replace the stickers and keep the "white pieces of paper" which "remained where the glue had refused to part with the wall" (53). Her refusal to buy new stickers suggests a recognition of the limitations placed on her as a woman by the society, challenging the perpetuation of the binarisms that dictate her life: Muslim modesty vs. western/secular immorality. As she writes:

It appeared as though there were Woman of Wonder ghosts all over my room, apparitions where she had once stood ground. For a long, long time after she vanished, these white spots were, to me, parts of God. (53) 
The harsh reality of losing the stickers that give her so much comfort reminds her of the challenges ahead, as she strives to makes meaning of multiple modes of being and belonging. While Esam's bursting of her bubble is cruel, the incident renders Nidali stronger, as her relationship with God and herself is strengthened. Following the incident, during her verse-memorizing sessions for the Koran contest, her father says "All your life, you'll remember these verses. I don't want you to be prepared just for a contest. Life itself is a test. Knowing these verses by heart will help you pass it, and will bring you comfort" ( A Map 45). Her father proves to be right, as Nidali seeks solace in Surah Al-Sharh, the verse of Comfort throughout her journey towards self-discovery: "With every hardship there is ease. With every hardship there is ease. When your prayers are ended resume your toil, and seek your lord with all fervor" (51). As Nidali moves from one country to the next, her faith does not contradict her multifaceted identity. On the contrary, Muslimness gives her comfort as the title of the chapter suggests, enabling her to express the complexities of her lived experiences. Throughout her memoir then Nidali offers a vision of Islam as a process, in Ahmed's words, "of human discursive and social activity $[\ldots]$ characterized by a multiplicity of voices" (297). Her victory at the recital competition, her observation of Ramadan with her family, and her occasional desire to pray, for instance, do not impede her sexual experimentations.

Although neither Nidali nor her family prescribes to the traditional teachings of Islam, Islamic references function as cultural markers that remind her of home from which she "was missing a hundred different things" ( A Map 221). "The sad part was," she writes, recalling her family's immigration to Texas, "I was starting to forget what 
they were and where home really was" (221). She finds herself waking up in the middle of the night, unsure of where she is, Kuwait, Egypt, or Texas (218). Her struggle to reconstruct home is further reflected in her uncertainty about her identity in the U.S, "Unsure of myself, of my appearance, of my accent, of my intelligence [...], if I could really, fluidly transition again" (219). Similarly, her father grapples with the rapid cultural and social changes that his family undergoes. In response, he holds on to the traditional values that remind him of his homeland. Nidali's homing desire, however, is articulated in terms of newness, as well as tradition, along with uprootedness, as well as attachment. She not only dreams of "a new life, an existential restart button, and a slice of pepperoni-less pizza" (237) but also of Ramadan, the call to prayer, zaatar burgers amongst other cultural signifiers. Nidali's displacement(s) then pave the way for her reinterpretation(s) of Islam, which is inextricably linked to her reinvention of herself. In the last chapter symbolically titled "Departure's Arrival," the act of becoming a writer against her family's objections instantiates the reconfiguration of Nidali's subjectivity as an Egyptian, Palestinian, and American Muslim woman. It is important that Nidali chooses to end her memoir with a reference to the fifty-second surah of the Koran, Surah Al- Qalam, "the Pen":

The PEN is a sura in the Koran that starts: "Nun. By the pen, and what they write, you are not mad: thanks to the favor of your Lord! A lasting recompense awaits you, for yours is a sublime nature. You shall before long see, as they will see, which of you is mad. (A Map 289) 
According to the Koranic tradition, the surah was a response to the non-believers and opponents of Prophet Mohammed. Moreover, the title of the surah alludes to a specific moment Nidali recounts at the beginning of her memoir where, her father changes her name from Nidal, a boy's name meaning strife, to Nidal-i after he finds out about her gender. "Baba," she recounts, "grabbed a pen and added at the end of my name a heavy, reflexive, feminizing, possessive, cursive, cursing 'I"' (5). In this context, writing her memoir is a transgressive act for Nidali in her ceaseless battle to exist on her own terms. Penning her memoir enables her to reclaim the "I" and to rewrite her reality as a Muslim Arab American woman into diasporic experience. "By narrating my own movements," she writes, "me became her, I became Nidali, you, she" (231). Her discursive construction of self as a symbolic prophet at the end suggests that writing becomes a sacred, liberating act. The act of writing allows her to reconstruct home within a textual space where her multiple identities can be coded and decoded. By carving out a space where she can capture the complexities of her identity as an Egyptian, Palestinian, American Muslim woman, Nidali re-creates a non-unitary self, unburdened by the binaries that mark the difference between her origin and destination — normative Islam and Muslimness.

\section{Conclusion}

In their novels, Abu-Jaber, Shafak, and Jarrar explore the lives of their Muslim migrant protagonists and present a mode of Muslimness that fluctuates and evolves through intercultural exchange(s) and displacement(s). While these new forms of Muslimness challenge orthodox Islam, they also have the potential to unsettle the 
established notions of national identities in Europe and North America. According to Salah Hassan (2012), it is often the double-bind in which Muslims find themselves that gives rise to new articulations of Islam. "Despite the reckless bombast of Islamophobes and Islamists," he writes, "the many Islams continue their migrations, moving into the future, giving rise to newness as they combine with other forms of culture" (87). In this context where the heterogeneity of Muslim populations is still overlooked, Muslim diaspora space as a conceptual tool magnifies how Muslim writers contest traditional categories of not only Islam but also "western-ness.” Ömer, Abed, Han, Sirine, and Nidali's estrangement does not make them turn away from their new countries; on the contrary, through the diasporic connections that they build, they inscribe their Muslimness and "foreignness" into social, cultural, and geographical spaces in the Global North. All three novels successfully highlight the contradictory ways in which the concepts of home, displacement, and Muslimness come into existence not in isolation but in relation to one another. 
Chapter 4: The Convergence of Islam, Feminism, and Queerness in Muslim Diasporic Writing: Aboulela, Janmohamed, and Tanaïs

\section{Introduction}

The convergence of Islam and feminism as a conceptual framework has been controversial since the term "Islamic feminism" was coined in the 1990s. At the center of the questions surrounding the debate on Islamic feminism, as well as on Islam and queerness, is the compatibility of disparate natures of Islam and a feminist-queer paradigm. Does Islam fit into a feminist-queer theoretical framework? Is Islam epistemologically at odds with the feminist praxis? Can the theorization of Islam within a feminist paradigm facilitate women's liberation and gender equality in Muslim countries? The significance of these questions for Muslim and feminist-queer paradigms is uncontested. As Saba Mahmood points out in Politics of Piety (2011), feminist projects have worked to integrate questions of sexual, class, and national difference in feminist theory, but the question of religious difference has remained understudied (1). The complexity of such crucial questions has ineluctably seeped into the literary discourse, specifically the study of Muslim writing that operates within a feminist-queer framework to counteract the structural inequalities that relegate women and LGBTQ Muslims to a second-class status.

In my previous chapters, I demonstrated how the lens of Muslim diaspora space can shift the discursive focus to the ways in which Muslim narratives escape the stagnations of religiosity, ethnicity, and nationality. This shift, I have argued, is 
characterized by a move towards an understanding of Muslimness as an episteme that is intrinsically ambivalent and diverse in the literary works of Laila Lalami, Leila Aboulela, Diana Abu-Jaber, Elif Shafak, and Randa Jarrar. Although I did not explicitly link my study of these Muslim writers to Muslim feminisms, my final chapter renders this link visible by presenting a discussion on the concept of "Islamic feminism" within the context of Muslim diasporic writing.

The past decade has seen a considerable interest in the predicament of Muslim women globally, which has led to the mass production of popular literary texts on the subject. As discussed previously, neo-orientalist narratives, which draw on Orientalist tropes about Islam, have gained unprecedented popularity since the Satanic Verses Controversy and 9/11. Gendered violence and radical Islam underlie these narratives, which are framed and marketed to appeal to the modern western reader. This is not to say that gender inequality, abuse, and violence are not prevailing issues that should be addressed urgently in Muslim societies and in western societies as well. These pressing issues certainly need immediate attention; however, essentializing stereotypical representations highlight a form of despotism imposed on Muslim women by orthodox Islam, disregarding political and economic systems, patriarchal norms, and the effects of neo-colonialism that underlie the issues of male privilege and subjugation of women.

While bestselling neo-orientalist writers and their contributions to the sociopolitical discourse about gender and sexuality are applauded, their perpetuation of the problematic representations of Muslim women found in the classical Orientalist texts such as Jeannette Pickersgill's Tales of Harem (1827), Julia S. H. Pardoe's The Romance 
of the Harem (1839) and Thomas Hood's A Tale of the Harem (1871) has engendered little discussion. In this final chapter, I use the analytic framework of Muslim diaspora space to highlight how Muslim writers contest the notions of Muslim feminisms as an oxymoron and offer alternative modes of Muslim womanhood from pious and nonpracticing to conservative and queer. To this end, I offer a close reading of Leila Aboulela's Minaret (2005), Shelina Zahra Janmohamed's Love in a Headscarf (2009), and Tanaïs's34 (née Tanwi Nandini Islam) Bright Lines (2015). By narrating the distinct struggles of Muslim women as they grapple with cultural and ideological negotiations, I suggest, these three novels complicate the notion of Muslim female agency and subjectivity. This attention to the specific ways in which Muslim women narrate and reclaim their Muslimness is critical in the current political climate. "In the post-9/11 era," as Jasmin Zine (2004) argues:

Muslim women navigate between both racialized and gendered politics that variously script the ways their bodies and identities are narrated, defined, and regulated. Located within this dialectical dynamic, the rhetoric of Muslim women's liberation is all too often caught up in the vast undercurrents of ideological extremism, on the one hand, and racism and Islamiphobia [sic], on the other. (168)

34 Islam explains the meaning behind the name Tanaïs: "the name I have given myself, is a portmanteau of the first two letters of my three names - a name that came to me after appearing on that list as a Muslim woman writer. I wanted to find a meridian between identities that honor where I've come from and where I am headed. "(“tanwinandini”, 2019) 
Aboulela, Janmohamed, and Tanaïs successfully offer a way past these constrictive dichotomies. While Aboulela and Janmohamed offer a nuanced understanding of Muslimness and empowerment that takes its note from the scholarly and philosophical Koranic traditions, Tanaïs foregrounds queer experiences of Muslim women in the diaspora. Despite the stylistic and thematic differences in their writing, Aboulela, Janmohamed, and Tanaïs all go beyond the patriarchal readings of the Koran, while challenging the Eurocentric mainstream expectations of Islamic gender politics.

\section{The Convergence of Islam and Feminism-What about Queerness?}

"Islamic feminism" is relatively new concept whose meaning is still in a constant state of flux. Scholarship on the Islamic feminist discourse is changing and evolving, and feminist scholars, historians, and sociologists have had various definitions of the concept. Historian Margot Badran (2009) defines Islamic feminism as:

a feminist discourse and practice that derives its understanding and mandate from the Qur'an and seeks rights and justice within the framework of the equality of women and men in the totality of their existence as part and parcel of the Qur'anic notion of all human beings. (324)

In Badran's formulation, Islamic feminism operates as a new form of paradigm that subverts the patriarchal teachings of Islam. Islamic feminism is feminist in the sense that its methodology entails the deconstruction, not subversion, of the gendered Islamic discourse. As Badran argues, its pluralistic nature stems from its ideal to "recuperate the idea of umma or Islamic community as shared space-shared by women and men equally and as a pluralistic community" (323). The common methodology of Islamic feminism 
thus includes reinterpretation(s) of Islamic texts to challenge male-centered readings of the Koran, as well as to advocate for a liberatory practice of gender equality as propagated by the Holy book. What is often overlooked in the discourse, however, is the plurality of both concepts; neither Islam nor feminism is a monolith. They may be ontologically in conflict; however, this does not necessarily suggest that they cannot blend through interplay and interaction.

Scholars of Islamic feminism suggest that, unlike feminism, Islam emphasizes the complementarity between sexes rather than equality. In Islam, it is the biological differences between sexes that determine the roles of women and men in societal affairs. Islam does not engage with the questions of gender; differentiation is based on sex. In the Koran, Islamic feminists contend, there is no evidence that male supremacy is sanctioned. On the contrary, as Asma Barlas (2013) explains, it is emphasized that "women and men originated in the same self, have the same capacity for moral choice and personality, and God's vice-regents on earth, have a mutual duty to enjoin the right and forbid the wrong" (421). The Koran further states: "Never will I allow to be lost the work of [any] worker among you, whether male or female; you are of one another" (surah 3:195). The misunderstandings that arise in relationship to the essence of Islam and the ways in which it operates as a tool of oppression stem from the long tradition of, what Leila Ahmed calls (2000), “an official, textual Islam, a ‘men's Islam”” (123). The Islam developed by men - sheiks, ayatollahs, clerics, mullah, and so on — Ahmed suggests, "created and passed on to one another this particular textual heritage," which has secured a single text to be the definitive "truth"' (125). As opposed to the hegemony of textual Islam, Ahmed 
emphasizes the common varieties of Islam(s). Secular feminists, however, have been suspicious of the Muslim woman's choice to practice piety and arrange her daily life around Islamic principles that "oppress" her, especially when there are other "liberatory" alternatives offered to her35. In this light, the Muslim subject's decision to be devout is axiomatically regarded as repressive, since it does not lead to any emancipatory action within the context of feminism as it operates under the principles of western liberalism.

Other preeminent scholars of Islam, too, take issue with the category of Islamic feminism. For instance, Amina Wadud (1999) and Asma Barlas (2002) argue that feminism as a discourse is inherently a western construct, a neocolonial legacy of EuroAmerican hegemony and hence is not compatible with Islam. Feminism cannot operate in accordance with the goals of pious women, for it effaces the possibility of theorizing gender equality from alternative intellectual paradigms. Fatima Seedat (2013) acknowledges the hybrid consciousness Islamic feminism engenders but recommends an alternative to the term Islamic feminism: the convergence of Islam and feminism as an articulation of struggles for equality through "a discourse that "takes Islam for granted"” (37). Seedat maintains that Islamic feminism is not the ideal understanding of "the intersections of Islam and feminism.” In fact, positioning the pro-faith discourse within the feminist discourse can lead to a misattribution of Muslim women's resistance in Muslim societies to a feminist consciousness or feminist politics imbricated in western perceptions of agency. Seedat's critique is crucial in the context of Muslim diaspora

${ }^{35}$ See Fernea (1998), Davids (2015), Dejeloul (2018), and Hesová (2019) for a comprehensive discussion on the challenges of Islamic feminism. 
space and raises the following critical questions: How are women who identify as both Muslim and western positioned in the Islamic feminist discourse? What about women who identify as Muslim and queer? Does queerness negate Muslimness?

I suggest that the Islamic feminist discourse, while crucial in putting forward a nuanced understanding of pious subjecthood, may run the risk of perpetuating restrictive dichotomies that it seeks to escape. For instance, queer Muslimness is not yet part of this paradigm, which leads to the propagation of a reified model of femininity and sexuality. Muslim diaspora space as a mode of analysis that emphasizes Muslimness as a dynamic and relational subjectivity can be useful in addressing this gap in Muslim feminism(s) studies. In addition to offering a conceptual lens to deconstruct the dichotomy between uprootedness and attachment, and secular and religious, Muslim diaspora space also brings to light, in Feedat's words, a "productive space from which to theorise modern Muslim gendered ways of being" (420). Since the framework of Muslim diaspora space contests political and cultural fixity and demands a recognition of the complex Muslim identity, ideological overlaps, and contradiction, it can also allow for the transgression of restrictive binaries that "Islamic feminism" may purport.

Scholarship on the intersections of queerness and religiosity has shown how, like Islam and female empowerment, Muslim practices and rituals are conceived as irreconcilably incompatible with LGBTQ subjectivity. As Wim Peumans (2018) demonstrates, the binary model of the west/freedom and Islam/persecution perpetuates the misconception that same-sex sexuality and Muslimness are antithetical to one another (200). Such binarisms, however, overlook the complex sexual and ethnic positionings of 
queer diasporic Muslims, as Alberto Fernández Carbajal (2019) argues, the (mis)conception that:

Islam is inherently homophobic and that the West is exceptional because it is the best place to be homosexual is politically dangerous, for this rhetoric can easily play into the hands of Western military interventionists and their apologists, whose continued interests in Muslim-majority countries is always on the lookout for moral justification. (16)

Carbajal's caution against the perpetuation of anti-Muslim prejudice is crucial. As he stresses too, however, queer Muslims are still often caught up in between Islamist traditionalist values that label them as blasphemous and the liberal progressive discourse that does not validate their Muslim identity. Momin Rahman (2014) points to the ways in which queer Muslims are doubly discriminated as they strive to reconcile "a social world where racism, Islamophobia, and homophobia intersect" (27). Although a comprehensive discussion on feminist and queer theories, as well as queer Islamic studies, is beyond the scope of this project, the starting point for this chapter is the binarist discourse that renders such negotiations difficult for queer Muslim diasporic subjects.

This chapter is thus particularly concerned with the intersections of feminism and queer theory and cross-cultural explorations of gender and sexuality within the context of Muslim diaspora space. In this spirit, I use feminism as an analytic template- in Gedro and Mizzi's (2014) words, "as a reference for queer theory in the way that it first questions assumptions about identity and then shifts private stereotypes, prejudices, inequalities, and limitations into the public sphere" (449). As Amanullah De Sondy 
(2017) notes, "Queering anything requires one to appreciate this complexity [of gender, sexuality, Islam(s)] and attempt to understand different contexts through their narrative and embodiment ("Why 'Queer' Islamic Studies"). The term “queer" in the context of Muslim diaspora space then signals a disruption of heteronormativity as well as Islamic heteropatriarchal principles. Queerness in this context highlights, in Carbajal's (2019) words:

that there is no inherent contradiction between sexual and ethnoreligious identities; if there's tension, it is not because of their imminent conflict, but rather because of the normative social workings of Islamic heteropatriarchy and of Western homonormativity, both of which are dominant but not fully representative of 'Islam' and the 'West.' (18)

Muslim diaspora space then allows for an inquiry into the specific ways in which diasporic Muslims reconfigure their gender and sexuality in relation to Muslimness as a lived experience. This reconfiguration is the starting point for my reading of Aboulela's Minaret (2005), Janmohamed's Love in a Headscarf (2009), and Tanaïs's Bright Lines (2015) that diversify and queer Muslim diasporic writing.

\section{Living in the Interstices as a Muslim Woman: A Close Reading of Minaret (2005),}

\section{Love in a Headscarf (2009), and Bright Lines (2015)}

Reading Aboulela, Janmohamed, and Tanaïs through the lens of Muslim diaspora space brings to light a literary site where Muslim female subjectivity and sexuality is explored in all its complexities. As discussed in Chapter 2, Aboulela's writing on pious diasporic subjecthood has received popular and critical attention. Her Muslim female 
characters often find empowerment and sometimes love through their embrace of Islamic principles. Similarly, the themes of Islam, freedom, and migration intersect in British Muslim writer Shelina Zahra Janmohamed's works. Written in the form of a chick-lit memoir, Janmohamed's Love in A Headscarf introduces a refreshing perspective on love and marriage. Both Aboulela and Janmohamed are celebrated as Muslim romance writers who also interrogate ideological entanglements in the tensions between tradition, female empowerment, and religion.

The New York based Bengali American author Tanaïs not only joins Aboulela and Janmohamed in dismantling the normative fetishization of the Muslim woman, but they also reclaim queerness as an integral part of Muslimness. Her debut Bright Lines, winner of Edmund White Debut Fiction Award and Brooklyn Eagles Literary Prizeamong many others, is the first Muslim narrative to present multi-faceted, fully fleshedout queer Muslim women characters. In this chapter, I demonstrate that the three writers contest the idea that Islam is in need of a reform; instead, they suggest that the patriarchal customs through which religious texts have been interpreted to serve socially constructed norms need re-evaluation.

In her groundbreaking chick flick memoir-fiction Love in a Headscarf, Janmohamed recounts the trials and tribulations of her ceaseless search for a husband through arranged meetings. Although the language of the text is couched in romantic terms, the complex entanglement of tradition and Muslimness is at the heart of Shelina's story. Shelina's primary concern are the prevailing stereotypes that generate distorted representations of Islam and Muslim women in the Global North. Her masterful 
combination of personal experiences with brief instructive analyses of Koranic verses and hadiths add a philosophical dimension to her text. She recounts her experiences on several disheartening dates in a Carrie-Bradshaw-and -Bridget-Jones tone, which mitigates the discrepancies between Muslim and non-Muslim women/readers. The memoir further emphasizes the similar challenges that most women, regardless of origin, race, and ethnicity, encounter when it comes to finding Mr. Right.

As Shelina writes about the complexity of love, she highlights the interstitial space that she occupies as an empowered Muslim woman. On one hand, within the Islamic community her decision to cover her hair "as a principle of my choice and empowerment" (Love 163) is simply overlooked, and she is disturbed by the misogyny that permeates her community's (mis) perception of Muslimness. On the other hand, she recognizes the ways in which the wider society, particularly following $9 / 11$, views her conservative dress code as a tool of oppression. "I was indeed suffering at the hands of an Asian Muslim culture that interpreted Western feminism as misguided," she writes, "And misguidedly interpreted Islam in order to subjugate women" (164). In a similar way, she notes that western feminism often propagates that "Muslim women have been brainwashed. You think you want to wear it [the headscarf] because your religious leaders tell you that is what a good Muslim woman should do, so you're complicit in your own subjugation" (152). In the chapter "Semiotic Headscarf," she critiques both Islamic and western liberal ideologies that seek to mold her into a monolith. She reflects on the ways in which she is often actively silenced in discussions on the question of headscarf. She writes as follows: 
Traditional Muslim men insisted that Muslim women should wear it in order to defend Islam. The voices in the media that hinted that Muslims were to be feared as stuck-in-the-dark-ages-violent-terrorists insisted that Muslim women should not wear the headscarf.

Could I say something, please? I thought.

I opened my mouth to speak but a Muslim man stepped in to defend me [...]

I'd really like to say something for myself, I thought again. (152, italics in original)

Despite her desire to contribute to the social discourse about gender, sexuality, and equality, "I was an inadmissible feminist" because "only Muslim women who had openly rejected Islam were allowed to be part of the discussion" (153). Caught between two prescriptive ideologies that "oppress[ing] me farther by telling me what to think (152), she rejects both by embarking on a spiritual journey to make meaning of her Muslim womanhood and the concept of love "in all its facets and to define it on my own terms" (243). On her quest towards self-actualization, the notions of Muslimness and love are disentangled from the web of patriarchy.

In a key episode, for instance, Shelina meditates on the demeaning "the trump card of the boy's superior cultural position and the marriage at-all-costs attitude" (Love 168) that plagues the society. Although she draws attention to her willingness in participating in the process of marriage as a family affair, she is soon exposed to the corruption of the whole matchmaking system. "My family took their Islamic responsibilities very seriously," she writes, "I had to agree to my future partner willingly 
and happily. What they were offering was an arranged marriage - something very different from a forced marriage" (25). Her insightful meditations on the underlying factors that cause each and every date to go horribly wrong reveal that traditional norms dictate the unwritten rules of such meetings that place emphasis on wealth, race, caste, skin color, and family name, which, according to Islam, "should not be part of the selection criteria at all" (Love 56). After several failed dates, she recognizes that Islamic principles and traditional norms are deeply, misguidedly entwined. She highlights, for instance, the racial and ethnic discrimination that tends to drive the system of "arranged marriage" in the diaspora:

...the experience through the marriage process was forcing me to ask difficult questions about whether the rules that we were socially obliged to follow really did adhere to the fundamentals of our faith. If they did, why was it considered almost unheard of to marry someone from a different ethnic group? (129).

The older generation's reluctance to cross ethnic, national, and religious boundaries is, she suggests, a way to hold on to the idea of home-as-homeland. She writes in reference to the "Aunties" who play the role of a matchmaker in her pursuit of love: "WWe had to move away from our homes, away from Muslim countries in order for us to really understand our faith of Islam,' said the Aunties... 'Back home' it was assumed that culture was 'Islamic"” (163). The conflation of restrictive traditional norms and Muslimness is further revealed in a scene where "Aunties" offer Shelina some advice about Muslim men. When Shelina continues to receive rejections from several Muslim men who seek an unveiled wife, the matchmakers ask her to be more "flexible" and to 
stop covering her hair "for a year" (168) — until she gets married. The paradoxical nature of their unsolicited advice exposes the repressive facets of traditional values that grant the "Aunties" the right to ask her nonchalantly:

to not do something which they all agreed was the right thing to do and to make it seem that I, the poor passive, accepting woman, was inflexible and lacking in kindness and understanding, and unwilling to show a commitment to the ideal of getting married if I didn't do it. (169, italics in original)

Shelina's inescapable encounter with the prevailing cultural machineries that operate merely "in the interest of getting the boy married" (Love 169) unearths the liberatory practices of her faith which are not imparted to young Muslim women who are often restricted by the sociocultural ideals. "Girls were offered two life settings: before marriage and after marriage," she writes, "So until I found a husband, everything else had to wait. Soon I would realize that this was a false dichotomy! And that actually I could quite happily get on with my life and search for a partner at the same time" (115). In addition to the conservative traditional values that often limit women's choices, Shelina criticizes the neoliberal ethos that dictates relationship norms. She discusses the difficulty of defining her identity as a Muslim woman seeking love because of the prevailing cultural focus on "beauty" and "sexiness." "You had to be sexy in the public domain to be accepted," she writes, "If you were interested in love, then it had to be a beautiful, glamorous, sexy kind of love. That is also why a Muslim woman talking about love is such an incongruous idea" (243). By deciding to set herself free from such sociocultural norms and formulaic definitions of Islam and love, she is able to make sense of her 
positionality at the juncture of British culture, Asian culture, and Muslimness. Her epiphany serves as a catalyst to the reconstruction of her Muslim identity, as she decides to shift her attention to her inner world, "making my spirit blossom" (Love 204).

The journey of self-discovery Shelina embarks on subsequently challenges the societal restrictions that relegate women to the periphery and "that constrained me from living my life, and from questioning, exploring, and practicing my faith to the fullest" (Love 130). "My faith as a Muslim," she elucidates, "is what created my vision as a human being. Where the two [tradition and faith] came into contact, and where there were contradictions, faith had to take priority" (129). Her reinvigorating insight into the interplay of faith and tradition allows for her liberation from the constraints of cultural norms; she climbs Mount Kilimanjaro, drives a convertible, visits her parents' birthplace Tanzania, and the Middle East with her friends. The warnings from Aunties and other women in the community that pour in is no surprise to her. In fact, she relishes the opportunity to refute the claims that such activities are unIslamic and "not the kind of thing a girl should do" (Love 131) through sophisticated analyses of the Koranic verses and hadiths. For instance, when an Auntie pressures Shelina to change her plan of climbing Kilimanjaro because "you are a girl and you have to know your place" (131), Shelina's witty response challenges the Auntie: "But God says that we should travel in the world and see His creations. In fact, He says several times in the Qur'an that we should travel His earth which He created for us" (131). She further goes on to recount the story of Koran's revelation to Prophet Mohammed in the Cave of Hira. She writes: 
There was irritated coughing. "This is, of course, a lovely story, but this doesn't change the fact that nice girls don't climb mountains. You have to take care of your reputation otherwise no one will marry you."

"Oh, but this does change everything, Auntie [...] This Cave of Hira is at the top of a very steep mountain which is no easy task to climb. Khadija would climb this mountain every day to visit the Prophet as he sat and meditated. The wife of the Prophet climbed a mountain. And I'm going to do the same." (132)

Shelina exposes the ways in which male superiority is often misguidedly couched in Islamic terms. She not only confronts the Aunties, but she also brings to focus how her decisions as a woman are constrained by traditional practices steeped in patriarchal cultural norms rather than Islamic philosophy itself. Shelina's conversation with the Auntie here further illustrates how calling into question Islamic principles distorted by tradition, misinterpretation, and power can be a liberating act. Her re-readings of the Koran enable her "to excel, explore, and discover $[\ldots]$ to investigate myself and everything around me" (Love 71). At the end, it is her constant exploration and investigation of her inner world, the Truth, as well as of other countries, peoples, and cultures that lead her to her husband-to-be, Najm.

As Shelina prioritizes spirituality and inner freedom, she recognizes the inextricable link between the Divine love and physical love, "that the two searches—for the love of a partner and for the love of the sublime - these two loves ran intertwined" (Love 189). "The search for love of the Divine could help me find the love I was looking for in a man," she writes, "My faith was trying to tell me that if I found love for Him, that 
would create the love I searched for in a person" (190). Before she meets Najm, she concludes her travels in Mecca, the Holy land, which serves as a cogent metaphor for her return to Britain as re-birth. Shelina's desire for change and renewal through her search for the Divine love empowers her to bring her voice as a Muslim woman to the front. Her spiritual and physical journey around Africa and the Middle East that ends in umrah, her visit to Mecca, instantiate the reconstruction of her subjectivity unshackled from the traditional and societal constraints. Not surprisingly then the narrative's epilogue, which offers a glimpse into her wedding day, is titled as "The Beginning." As Janmohamed concludes her story, she brings it full circle to her childhood home where it all began with her first suitor. "I step into the car, about to begin the journey," Shelina writes at the end, "and say as I always do at the beginning of any action: Bismillah Ar-Rahman Ar-Raheem, In the name of Allah, the Lovingly Compassionate, the Kind" (253). The lens of Muslim diaspora space brings into the open the challenges that Muslim women encounter in the Global North, as well as the possibilities for alternative modes of Muslim womanhood. Janmohamed's emphasis on Muslimness as a tool of liberation demonstrates the importance of escaping the confines of binaries that perpetuate a fixed notion of Muslim female subjectivity.

Love in A Headscarf aptly provides the context for the protagonist's struggles in Leila Aboulela's Minaret as a "born Muslim" who embraces her faith in the diaspora. Najwa opens her narrative in the name of Allah-Bism Allahi, Ar-rahman, Ar-raheemand reminds the reader of a line that sticks with her after a Koran lecture: "The mercy of Allah is an ocean. Our sins are a lump of clay clenched between the beak of a pigeon" 
(4). The first chapter strategically situates Najwa's narrative in a Muslim framework. Its significance also lies in the implicit suggestion that the project of narrating her story is a redemptive act through which Najwa rewrites her Muslimness. Beginning in 1984, Minaret spans twenty years, charting the drastic changes that Najwa undergoes after her father is executed at the beginning of the Second Sudanese Civil War in 1983. Najwa is compelled to leave Sudan for Britain with her mother and brother to escape execution. Raised in a privileged, affluent household in Khartoum, Najwa's reality alters in London. Following her mother's death and her brother's imprisonment, she feels a deep rift within herself. The novel offers a glimpse into Najwa's spiritual journey towards self-realization as she starts rebuilding herself from rock bottom in London.

As the opening of the novel indicates, Najwa's Muslimness anchors her soul, as well as her diasporic identity. Within the context of Muslim diaspora space, the connections Najwa makes with other Muslims in London across ethnic, racial, and religious differences generate opportunities for crossing figurative borders. Like Shelina who emphasizes her faith as a choice "about the way that I wanted to live my life" - a choice made "on careful thought and what I believed was right" (Love169), Aboulela places the Muslim woman's agency — the right to choose to be a Muslim woman -at the heart of Najwa's story, challenging academic, social, and political discourses that foster false dichotomies about the oppressive ways through which women are "muslimized" in their communities. From the beginning, Aboulela underlines how Muslimness paradoxically remains foreign to Najwa in Khartoum where she revels in financial and sexual freedom granted solely to upper-class women. Her past is marked by an 
overabundance of parties at the American club, sexual indulgence, recreational drugs, and emotionally abusive boyfriends. The juxtaposition of her past with her present steeped in Muslim rituals highlights the arduous process of becoming that recreates her identity as an empowered Muslim woman in Britain.

In her discussion on the notion of agency in the formation of Muslim female subjectivity, anthropologist Saba Mahmood (2014) critiques western formulations of agency that unreflectively invalidate the Muslim woman's conscious decision to be devout. According to Mahmood, it is critical to question the ideal of freedom and liberty as a western political ideal and to "detach the notion of agency from the goals of progressive politics" (14). Mahmood's inquiry of various modalities of agency whose meaning and effect can be accommodated outside the notions of subversion is necessary for our understanding of Muslim women's positionality at the intersection of Muslimness and empowerment. In this context, detangling the notion of agency from the feminist project that prescribes a politically subversive subjectivity for Muslim women (Mahmood 154) can yield a more nuanced understanding of multiple modes of Muslim womanhood. Reading Najwa's rite of passage, like Shelina's, through the lens of Muslim diaspora space thus requires readers to engage with the text beyond the all-too-familiar stereotypes about Muslim women.

For instance, Najwa reconstructs her identity in a twenty-year span through trials and tribulations. Having felt a spiritual void for years, she makes the conscious decision to seek solace in Islam. She reflects on the emotional discomfort that made her restless in Khartoum. She recalls "the girls in Khartoum University wearing hijab and those who 
covered their hair with white robes [...] the rows of students praying" and how she “envied them something I didn’t have but I didn’t know what it was. I didn't have a name for it." (Minaret 134). Although daily life in Sudan is steeped in Muslim rituals and practice, she is never cognizant of their existence. "Whenever I heard the azan in Khartoum, whenever I heard the Qur'an recited," she writes, "I would feel a bleakness in me and a depth and space would open up, hollow and numb" (134). Like the majority of Muslim characters I have studied in this project- from Esteban to Nidali, Najwa's recognition of such absences in the diaspora activates her transformation. As she reflects in a conversation with her lover, her employer's brother, Tamer: " For a brief moment I am not sure who I am, the Najwa who danced at the American club disco in Khartoum or Najwa, the maid Lamya hired by walking into the Central Mosque one afternoon" (111). The realization that she is neither and both at the same time enables her to find comfort in the liminal space she inhabits in the diaspora; she thus finds the courage to delve into that "space that would open up" in Sudan which, she realizes, is actually dynamic and deep.

She is introduced to the Muslim diaspora community after her mother's death when women from the mosque help her wash her mother's body. Najwa finds this cleansing ritual intriguing as the women teach her a specific prayer "asking Allah to wash my mother's sins with water and ice" (Minaret 135). After the ritual, Najwa kindly rejects the women's invitation to the mosque, "Couldn't they see that I was not the religious type?"; however, the prayer and "the image of ice remained and the feeling she imparted that my mother needed me still" (135). When she decides to visit the mosque a few days later, the diversity of the women at the mosque surprises her. The girl reciting 
Surah Ar-Rahman on the floor, teenagers in jeans and headscarves, middle-aged businesswomen, whispers in foreign languages - Turkish, Arabic, Urdu — capture Najwa's interest. The warm welcome she receives from the mosque community despite "[her] lack of religious upbringing, no degree, no husband, no money" (239) allows Najwa to recognize the irrelevance of her past, giving her the opportunity to rebuild herself.

Returning to Mahmood's discussion the notion of agency is illuminating in this context. Mahmood suggests that western liberal paradigm often overlooks the Muslim subject's decision to embrace Muslimness as an emancipatory way of life. However, "Norms are not only consolidated and/or subverted," Mahmood explains, "but performed, inhabited, and experienced in a variety of ways, pushing the question of norms further in a direction that I think allows us to deepen the analysis of subject formation" (22). In this light, in order to fully understand Muslim women's positionality against the oppressive tenets of both dogmatic and liberal discourses, a comprehensive analysis of the political, cultural, and social spaces where they engage in meaning making process is required. Although Najwa, like Shelina, throws norms into question, her decision to wear the headscarf and immerse herself in Muslim practices and rituals should not necessarily lead to the perception that her subjectivity is purely resistant, detached from a sense of pious self. Her decision to be veiled is not a political act of subversion per se. Rather, the meaning and effect of her practice can be understood not only in secular terms of selfempowerment but also in religious terms of virtue because she is able to cultivate a Muslim self through the act of veiling, or in Mahmood's words, "bodily acts" (158). The 
re-construction of self, in this context, is secured through repeated bodily acts that enable her to train her desires and her sense of self.

These acts — the act of veiling, for instance — are not mere markers of exteriority and physicality; on the contrary, bodily acts cannot be divorced from an interiorized self. For instance, after Najwa is introduced to her study group at the mosque, she feels that it is not sufficient for her to reach the modesty she desires without wearing the headscarf. After she begins wearing the headscarf, "sometimes the tears ran down my face," she writes, "I sweated and felt a burning along my skin, in my chest. This was the scrub I needed" (Minaret 247). Her emphasis on the "exfoliation, clarifying, deep-pore cleanse, words" that "I knew from the beauty pages of magazines and the counters of Selfridges," of "my soul not my skin" (247) underlines the intimate link between interiority and exteriority through which she reconfigures her Muslimness. Bodily actions then are reinforced and utilized to acquire a sense of virtuous self. If the women take off their headscarves, for example, their sense of Muslimness is undermined because the veil serves as an outward bodily marker of both piety and self-empowerment. As Mahmood states, this is an important aspect of veiling which is overlooked when the headscarf is judged merely in terms of its symbolic value as a marker of women's subordination or political resistance (159). Despite the overt political implications of the act of covering up, Najwa's transformation highlights a mode of pious subjectivity that moves beyond political resistance and operates as a means to cultivate an empowering Muslim womanhood. 
Najwa's headscarf serves as a tool through which she unlearns and re-learns everything about being a Muslim woman. Najwa is able to reconcile her disparate positionalities by reconfiguring the meaning of "liberation" as she participates in the women's study group at Regent's Park masjid, London Central Mosque. Her decision to wear the headscarf, to pray and participate in the Koran study at the mosque inculcates in her the spirit of piety, offering an alternative mode of freedom—not only from her past but also from all the political and cultural ideologies that have constrained her from being true to herself. Moreover, the disheartening scene when Najwa is terrorized on the bus because of her Muslim identity shows that the anti-Muslim sentiments, which drastically increased after $9 / 11$, strengthen her connection to her faith. This episode takes place in 2003 after the War on Terror launches. On the bus, three young men hurl racist remarks at Najwa, calling her a "Muslim scum" (Minaret 80) They move on to humiliate her by pouring soda on her head and face. Petrified, Najwa is unsure about how to react; she is dehumanized and scared but takes comfort in the surah, Lord of Daybreak: "I tell myself that Allah will protect me, that even if they hurt me, I won't feel it too badly" (80-1). In addition to underscoring the sociopolitical context of the novel, Najwa's experience on the bus demonstrates the double discrimination that Muslim women, particularly those wearing the headscarf, a visible marker of Muslimness, may experience. Najwa's reflection on the incident further proves that her laudable efforts to cultivate a pious sense of self do not cancel her political awareness. Her vulnerability in the wider society, however, brings her closer to the Muslim diaspora community that is increasingly perceived as a threat to British society. 
The Regent's Park masjid as the central setting of the novel gains in importance within the context of Muslim diaspora space. The women's ethnicity, race, clothing, and language as markers of difference in public space are complicated once they enter the masjid which configures as a territory-less space where ethno-national, racial, and sectarian boundaries are crossed. It also becomes a space of empowerment where the women — from Malaysia, Syria Turkey, Sudan, India, as well as locals from Britain— show solidarity against patriarchal norms that perpetuate their subjugation. The women meet every week to discuss and examine religious texts from a gender perspective. As Najwa recognizes cultural articulations of patriarchy that permeate Islamic ideology, she makes meaning of her multiple positionalities in diaspora space as a Muslim and a woman. Like Shelina, Najwa demonstrates that being modest and Muslim does not negate her sexual desire, as well as her search for love and joy. Her relationship with Tamer and her sexual fantasies (Minaret 215) provide a case in point. However, the end-of-Ramadan party that the study group throws at the mosque is an excellent example that challenges the secular tendency to label Muslim women as inherently oppressed, along with the traditionalist interpretations of the Koran that confine women to an inferior essence.

Before the Eid party begins, the preacher, Um Waleed discusses the importance of Ramadan and reviews the entirety of the month when the women met every night for taraweeh prayers. Seeing the preacher dressed up for the party, Najwa notes, "Without her hijab, in a tight crimson party dress, her hair tinted, her face brimming with make-up, she looks so Arab, so unsubtle that I think this is how she is, her secret self $[\ldots]$ her own excitement over life" (Minaret 185). After Um Waleed's speech, the festivities begin. As 
Najwa watches her friends dance, she narrates, "Around us, the mood is silky, tousled, non-linear; there is tinkling laughter, colours, that mixture of sensitivity and waywardness" (183). She surveys the prayer hall, now filled with the women from her prayer group, all unveiled, dressed in colorful, revealing, and traditional clothing, hairs done, nails polished, and having fun. Emphasizing that there is more to the women than their headscarves, she writes, "It is as if the hijab is a uniform, the official, outdoor version of us. Without it, our nature is exposed" (186). By bringing women of different ethnicities, races, and levels of piety together, Aboulela underscores the important role of agency both in using the headscarf as a tool to complement her women characters' modesty. She also successfully contests the gendered parameter of the Muslim diaspora in the Global North.

Despite the challenges that $9 / 11$ posed for her and her community, in the mosque Najwa finds "a new peace and a new community" (Minaret 67). The mosque as a space of dynamic encounter opens up a possibility for Najwa to jettison the parts of her past, as well as the political ideologies that no longer serve her. This is best illustrated in scene where Najwa and Tamer discuss their Sudanese identity. "My mother is Egyptian," Tamer tells her, "I've lived everywhere except Sudan: in Oman, Cairo, here." He goes on:

My education is Western and that makes me feel that I am Western. My English is stronger than my Arabic. So I guess, no, I don't feel very Sudanese though I would like to be- I guess being a Muslim is my identity. What about you?" 
I talk slowly. "I feel that I am Sudanese but things changed for me when I left Khartoum. Then even while living here in London, I've changed. And now, like you, I just think of myself as a Muslim.” (110)

For both Najwa and Tamer, Muslimness emerges as a powerful identity marker in London. Being "Western" or speaking "English" does not negate Najwa and Tamer's Muslim identity; on the contrary, the diaspora space they inhabit enhances their Muslimness by offering them an alternative mode of being a Muslim with no economic, sociocultural, political, and familial influences. Throughout the novel, the multifaceted nature of Najwa's identity is highlighted. Aboulela writes Najwa's story with an Islamic imaginary; she is depicted as a pious Muslim woman with a past complicated by civil wars and political corruption; a woman who also seeks love and lust. Aboulela thus uses the diaspora space that is London as a means to empower her female protagonist. This empowerment, however, is not characterized by sexual liberation or political resistance. Instead, Najwa is able to develop a coherent sense of self in terms of Muslimness, challenging the mainstream notion that "unless you're political, people think you're not a strong Muslim (Minaret 48) as Tamer complains. Even after Najwa and Tamer discuss marriage, Najwa, like Shelina, prioritizes her relationship with God and goes on a pilgrimage to Mecca, which concludes the novel. Through her protagonist who unsettles both Muslim and non-Muslim ideologies, Aboulela challenges the formulaic tropes used to defined the Muslim woman, showing that Muslim practices and rituals that may appear to signify submission to the system of patriarchy from a progressive point of view may in 
fact be a form of empowerment. Like Love, Minaret disorientates gendered narrative structures by bringing to the fore the ways in which their Muslim characters transgress Islamist patriarchal traditionalism, anti-Muslim prejudices, and the progressive liberal feminist discourses all of which work to further push them to the fringes of society.

Like Janmohamed and Aboulela, Tanaïs undertakes producing a Muslim narrative that reclaims the female body in Bright Lines. Tanaïs, too, pushes against socio-culturally enforced national, ethnic, and patriarchal boundaries; however, she focuses on nonnormative female sexuality by creating contexts which enable her diasporic characters to reconcile queerness and Muslimness. Set in the summer of 2003 in New York and the winter of 2004 in Bangladesh, Bright Lines is a hefty coming-of-age story that brings together its main characters, Moroccan Egyptian American Maya, Bangladeshi American Charu Saleem, and her cousin Ella Saleem who was orphaned during the Indo-Pakistani War of '71. Following the murder of Ella's parents', her aunt and uncle Hashi and Anwar Saleems, who immigrate to Brooklyn after the civil war breaks out, adopt Ella. The novel charts Ella, Charu, and their friend Maya's sexual awakening, as they spend the summer before college on a quest towards self-realization. In the face of intersecting predicaments of migration, belonging, and homing desire, Ella and Maya learn to negotiate their diasporic identity, religious morality, and heteronormative expectations around sexuality and gender. This reading of Bright Lines through the lens of Muslim diaspora space highlights the ways in which Tanaïs breaks new ground by placing queerness at the heart of Muslim diasporic experience. 
Tanaïs is concerned with the difficulty of reconfiguring the queer Muslim diasporic self. In doing so, they challenge the dominant narratives about diasporic queer Muslim subjectivity. Although Muslim rituals and practices loom large in Tanaïs's diasporic imagery in the novel, Maya and Ella's dance around cultural and religious restrictive norms best illustrate how Tanaïs unsettles the tendencies to portray Islam and queer identity as a monolithic whole. They introduce Maya, Charu's friend whom she meets at Sunday Koran study, on the very first page of the novel. The text opens with Anwar Saleem sitting in his Apothecary located between Ye Olde Liquor Shoppe and A Holy Bookstore — owned by an Islamic cleric Salah S., Maya's father, who becomes emotionally abusive towards his family following his wife's diagnosis with a terminal illness. Anwar catches a sight of a girl climbing down the fire escape, as she "peel[s] off her hijab, revealing hair cropped as short as Audrey Hepburn's" (Bright Lines 4). Anwar, however, is not yet aware that the girl, Maya, heads to his house to stay with Charu where she takes refuge after her argument with her father who refuses to send her off to college.

This is where Ella meets Maya for the first time one night when she finds her tucked in her bed. During Maya's stay with the Saleems, Ella occasionally feels a pang of love and desire which she continues to repress. The "forbidden thoughts" (Bright Lines 49), the narrator emphasizes, date back to Ella's childhood and are not her only secret. Since her parents' murder, Ella has been hallucinating; visions of strangers, plants, "a waning moon over a placid lake, a bevy of Egyptian blue monarchs, a television set bouncing up and down around the room" (22) all come to her in bright colors and various shapes. As a kid, she fears that her uncle and aunt would send her back to Bangladesh if 
they find out about her visions; as she gets older, she cannot figure out a way to tell them. Cognizant that "it was either a tumor or trauma that caused her phantasms" (23), Ella thus does not tell anyone—except Maya — about her visions until the family's visit to Bangladesh. In Maya, Ella finds a friend in whom she can confide, as well as a lover who helps her start her journey towards self-definition.

Maya's relentless fluidity enables Ella to see ambivalence, difference, and contradiction as a positive force. It takes her a while to process Maya's multiple subjectivities as a Moroccan Egyptian queer Muslim girl. Maya is committed to the headscarf, daily prayers, and to attending the mosque, and she unapologetically embraces her identities. One morning, Maya's alarm wakes Ella up at dawn, and Ella sees Maya whispering her prayers knelt in prostration. After acknowledging Ella's existence, Maya tells her, "I'm almost done. This is the part you ask for stuff" (Bright Lines 50), referring to the practice of making $d u a$ at the end of each prayer. "Ella waited for her to finish," the narrator states, "after a few more whispery requests, Maya turned her head to the left, then the right, then clasped her hands once more. As she rose up her knees popped like bubble wrap, and she laughed" (50). Despite her fascination with Maya's willingness to wake up so early to pray, Ella begins to comprehend Maya's commitment to Muslim rituals and practices, as she finds out that Maya's faith guides her way of being and acting in the world. The following day, Maya convinces Ella and Charu to take a day trip to a gay beach because “rather than get undressed with someone's eyes, don't you like the idea of being naked on the beach?" (52). The bike ride to the beach, the first of the many throughout the novel, marks a threshold for Ella, as she observes how 
unapologetically Muslim Maya is. On their way to the beach, they stop at a cornerstone to buy snacks. When Maya goes for sliced ham, Ella asks her "You eat ham?":

"My first babysitter was a Puerto Rican girl. I begged her to let me eat ham cheese sandwiches and one day, she finally did," said Maya, chuckling. “I just started eating pepperoni last year and now I'm addicted," said Charu. (53) Although Ella and Charu, too, are from a Muslim background, the owner of the shop who overhears the girls' conversation asks Maya, "You gonna eat this? Ain't you a Muslim?" To which Maya responds curtly, "Yup" (53), suggesting that her answer to the two different questions is yes, and that eating ham does not detract from the value that she places on her headscarf and her relationship with God.

In an effort to transgress the dichotomy between the internal and the external, Tanaïs uses the headscarf a trope that contests its representation as a mere political symbol. In a scene where Charu, an aspiring fashion designer, introduces her new collection of headscarves, which she wittily calls "either haute hijabi or jihadi hotties" (Bright Lines 77), she dresses Maya in a bright-colored headscarf for a night out. Unable to stop staring at Maya, Ella thinks Maya "looks like a Muslim version of Spiderwoman" with her suggestive red lipstick and the skintight black jumpsuit she wears (77). Later, when Ella and Maya attend the mosque, Ella observes the shift in Maya's demeanor at the masjid. "She was different," the narrator states, "from the ham-eating, bike-riding spider-woman-jumpsuit wearing girl Ella had come to know this summer” (133). Despite the shift in her attitude, Maya's pious and queer identities are not placed in opposition to one another; on the contrary, they complement one another as aptly 
illustrated at a warehouse dance party: "Maya walked with a tightrope walker's poise forward and backward to her own rhythm. A breeze crept into her hijab and the multicolored fabric flew around her head" (124). For Maya, covering her hair is a form of self-expression, enabling her to cultivate a Muslim self without negating other aspects of her identity.

Throughout the novel, Tanaïs reclaims queer Muslimness through Maya's ambiguous and fragmented identity, disentangling the restrictive Islamic prescriptions from Muslimness which emerges as a compass. For instance, on the gay beach, Ella watches Maya remove her headscarf and undress. When she asks her about the meaning of the Arabic tattoo etched on her left rib, Maya explains that it is a line from the Surah al-Qamar: "The hour has come near/ the moon is split in two/ they see a miracle/ they turn away and say/ it is passing magic" (Bright Lines 55). The 54th surah of the Koran narrates the story of a miracle Prophet Mohammed performs by splitting the moon in two in Mecca. A response to non-believers, the splitting of the moon within the context of the Koran can be read as a metaphor for the emerging religion and its official symbol, the crescent moon. 36 The inscription of these lines on Maya's body represents not only the ongoing process of reconfiguring her identity as a queer diasporic Muslim who inhabits in-betweendom, but it also points to the ways in which the queer body can claim ownership of Islam. Maya's response to Ella’s comment “I thought Muslims weren’t allowed to get tattoos," highlights how she pushes against the binarisms that define her.

\footnotetext{
36 Since the Islamic lunar calendar made the crescent moon the symbol of Islam.
} 
She tells Ella, "Can't think of anything that is more godly than tattooing God's words on myself" (55). When it is time for the maghrib prayer, Maya steps aside and uses a beach towel as a prayer rug. Ella, too, vicariously finds comfort in Maya's prayers: "she held her breath during Maya's prostrations, thankful for this respite from her solitude" (57). The act of praying on a towel, on the gay beach is highly contradictory not only in the Koranic injunction but also in secular progressive discourses. Maya's namaz thus serves as a symbol through which Tanaïs subverts the mainstream perception that Muslimness and queerness are mutually exclusive. Following this line of symbolism, for Ella, Maya herself performs miracles by disorienting the normative gendered and religious structures. As the narrator depicts Maya on her bike through Ella's perspective, "her hijab sail[ing] behind her like a kite, as if she might levitate" (53). In a way then Maya is Ella's miracle that opens up the space for Ella's quest toward self-realization.

Although Ella does not transition into a man until after her turbulent visit to Bangladesh, the masjid scene in the summer of 2003 anticipates the life-changing shift in Ella. When Maya is compelled to leave the Saleems' due to a family conflict, she takes refuge in the masjid. Ella who follows Maya to the prayer house realizes that it must be time for fajr, the morning prayer, "Maya's prayer," (Bright Lines 132) as she calls it. This is Ella's first time at a prayer house; although her deceased father was a firm believer in Allah, her uncle, still a Muslim at heart, has stopped attending the mosque after the death of Ella's parents. Ella's sudden headache - anticipating her visions — at the masjid implies that the trauma of losing her parents and her heritage may indeed be the source of her hallucinations. Despite the discomfort, Ella finds herself fascinated with the mosque 
"covered in plush Turkish carpets and a stickered wall of a hundred hologram Allahs" (132). After Maya helps Ella tie a headscarf around her head, she follows Maya's motions, and they pray, starting in their feet, bending over their knees with a flat back, and sitting down on the rug. What is curious here is Ella's vision as she sits on the rug, waiting for the completion of Maya's duas. As her headache worsens, "the glittering wall of Allah decals" begins to "twinkle under fluorescent lighting, waxing and waning rainbow shapes" (133). Similar to the prayer on the gay beach scene, the masjid episode evokes the LGBTQ rainbow flag to foreshadow the necessary collapse of the dichotomies between secular and religious, and more specifically, queer and Muslim. The merging of Allah decals with different rainbow colors and shapes further represents Maya and Ella's assertion of their queer subjectivity into Muslim spaces. Within the context of Ella's journey, her vision of rainbow(s) also emerges as a symbol of hope and acceptance, for Ella's transition begins on the last day of her visit in Bangladesh after she embraces her hallucinations, as well as all her different "colors."

Tanaïs thus successfully creates local and global contexts where Muslim identity marked by queerness is no longer an oxymoron. In Part I set in New York, she presents a community of young Muslim Americans whose Muslimness finds expression in nonnormative queer aesthetics. The warehouse party that introduces Ella to this counterculture is an excellent example in this context. At the party, Ella meets a diverse group people of different sexual orientations and backgrounds, from Maya's ex-boyfriend Halim who is now openly gay and Anwar's friend Rashaud Persaud who is a crossdresser (Bright Lines 97, 127) to Maya's lesbian friends, the "two girls in different shades 
of lipstick, lip-locked" who greet Ella with "as-salaam-alaikum" (124), clearly marking their identity as Muslim. Fascinated, Ella observes:

Young people strut[ing] at all corners of the spot, leaning against walls, waiting in line for the bathroom, vogue-dancing in the center of the room [...] Black, yellow, and brown kids rock[ing] wondrous hair-styles. Braided, dyed, feathered, twisted, cornrowed, flat-topped, matched with mesmerizing fashions-stirrup pants, Adidas tracksuits, tattoos, piercings, spray-painted sneakers. She envied their freedom. (125)

Tanaiis brings together Muslimness and Americanness in a way that transcends both socially enforced heteronormative norms and the constraints of Islamic dogma. The authority of familial values and clerics is contested here, as the young Muslim Americans redefine Muslimness as well as Americanness based on their lived experiences. Moreover, the juxtaposition of Ella's desire to be as free as the "cool kids" at the party with her self-actualization in Bangladesh unsettles the linear, holistic narrative that glorifies the Global North as the source of freedom while propagating the assumption about Islamic backwardness. Tanaïs deconstructs the authority of any one single narrative about LGBTQ subjectivity, highlighting the role of different familial, religious, political, and economic ideological entanglements in the process of "coming out." In Queer Muslims in Europe (2018), Peumans demonstrates that popular and academic discourses on diasporic queer Muslims center around the process of moving from a closet in the homeland as a fully queer person, "waiting to burst out of the closet one leaves behind" (5) in the host society. By enabling Ella to start her transition in Bangladesh, Tanaïs 
reverses the theological narratives of progress that misguidedly emphasize the superiority of western paradigms.

After a difficult summer, Anwar and Hashi decide to take Ella and Charu to Bangladesh for the first time, encouraging them to familiarize with their heritage. In Bangladesh, Ella spends most of her time with her grandfather and her half- brother Rana to learn more about her parents. However, in a key episode where Rana shows Ella around the city, Ella unexpectedly recognizes the importance of negotiating her sexual orientation to live a meaningful life. As they

drive by a slum, she spots a hijra, a transsexual woman:

"Are there a lot of people—like Tina here?" Ella asked.

"Hijras?"

"Yeah." (Bright Lines 203)

The representation of hijras in the second part of the novel aptly reflects the ethos of the novel. In this episode, Tanaïs not only brings to the fore the issues of race and ethnicity in discussions about gender and sexuality, but she also emphasizes that queer identity is not fixed. Rana emphasizes the different modes that a transsexual identity can take. "Yes. There are different shades, of course," he tells Ella, "Some emasculate their penises; some don't. Many are charming and pretty women; others don't consider themselves men or women. It's complicated" (203). Encouraged by her brother's close friendship with the transgender woman Tina, she asks him whether "there is a word for the other way around?" Ella's inability to even articulate the words "a woman who lives as a man" (203) shows how difficult it is for her as a young adult to grapple with unnamed or 
repressed aspects of her identity. The word Rana teaches her, however, allows her to imagine what it would feel like to be free and prompts Ella's transition. Rana tells her that "Swadhin" is a word that is used for a transsexual man in India: "It's a good word swadhin, meaning ultimate liberation $[\ldots]$ a female finding salvation by becoming a man" (205). For the rest of her trip, as Ella confronts the series of trauma that trigger her hallucinations, from the death of her parents and leaving her grandfather to her desire for women and her inaptness, she grounds herself in the implications of the word, swadhin: "Swadhin, thought Ella. Ultimate liberation. She repeated the word. The word filled her up the way her visions did. She felt more complete, somehow" (249). As Ella's feelings of pain and confusion are gradually replaced by empowerment and inner growth, the narrative voice strategically shifts from the personal pronoun she to he, and Ella becomes "El."

The novel ends with El's return to New York with a renewed sense of self. However, Tanaïs highlights that this is only the beginning of his transition. Following his sexual awakening illustrated in a scene where Maya and El get intimate for the first time, the narrator fast-forwards to offer a glimpse into El's future:

Over the months, and eventually years, El will see more of Rezwan, Rana, and Anwar in himself. Swadhin, or salvation, comes from changing course altogether. He will speak in the tenor of a pubescent boy, until a resonant bass settles. He will sprout a mustache and beard that would have made Anwar proud. Each time, there will be a rubbing alcohol stream, a prick of the syringe, fluid in his vein. He 
will become a cartographer, inking a border town beside a river on a map. Each time, closer to completing his atlas. (290)

This passage that anticipates El's physical transition encapsulates the process of deconfiguration and reconfiguration involved in the queer Muslim diasporic experience. El's journey toward self-definition involves a move back and forth between the homeland and "home"; it involves losing and finding himself. Tanaïs then ends the novel on a hopeful note for the reconfiguration of queer Muslimness - which can be shaped and reshaped by transnational, contradictory, and sometimes ambiguous moralities and sociocultural frameworks. In addition to foregrounding distinct experiences of Muslim women in the diaspora like Minaret and Love, Bright Lines also gives overdue visibility to issues with which queer Muslim women grapple.

\section{Conclusion}

In their texts, Aboulela, Janmohamed, and Tanaïs implicate alternative modes of Muslim female empowerment, as well as notions of transnationality in the construction of the Muslim female-queer subjectivity. That is to say, the form(s) of empowerment that the writers present is not a version of secular feminism nor does it prescribe to the dogmatic readings of textual Islam. Rather, it intersects with and pushes in elements of Islamic thought and feminist-queer thought in new directions within a transnational context. There emerges then a literary representation of diasporic Muslim subjectivity that resists the restrictive heteronormative, homophobic, and discriminatory impulses of both conservative Islam and secular liberalism. 


\section{Conclusion}

Throughout this project, I have argued for the importance of reading Muslim diasporic writing through a postcolonial cultural studies method that unsettles the fixed categories of "Muslim" and "diaspora." I have shown that the Eurocentric discourse on Muslim identity endorses a narrative that wraps Muslim identity in a single religious ideological cloak, reducing the multiple subjectivities of Muslim migrants and citizens in the Global North to a monolith. The lack of emphasis on literary texts and the role of imagination in studies of Muslim diaspora, I have argued, reinforces the reductive tropes that have emerged with renewed force since the recent surge in Islamophobic rhetoric both in the U.S. and Europe. In an effort the address this gap in literary and diaspora studies, I have pointed to the need to re-imagine the processes of production, consumption, and circulation as situated at a Brahian point of dynamic encounter where Muslimness is both transculturalized and translocalized - through the lived experiences and practices of those who identify as Muslim.

Focusing on imagination and self-representation as a key sociocultural force in the context of Muslim diasporas, I have demonstrated that Laila Lalami, Leila Aboulela, Diana Abu-Jaber, Elif Shafak, Randa Jarrar, Shelina Zahra Janmohamed, and Tanaïs create diasporic contexts that allow diverse Muslim characters to interact among themselves and relate to the larger society. In reconceptualizing "Muslim diaspora" through a literary lens, my goal has not been to erase religious subjectivity; rather, I have cautioned against the reduction of the Muslim subjecthood to a single ideological element. Muslim diaspora space as a mode of analysis, I have suggested, brings to light 
the ways in which writers of Muslim origin transgress the generic theme of "East Meets West," emphasizing authorial intention to refuse polarizations encrypted in the signs of "nation," "Islam," and "the West."

My contrapuntal reading of various Muslim narratives through the lens of Muslim diaspora space has highlighted the ways in which the notions of Muslimness and westernness are constantly being disoriented and re-oriented in these works of literature. Despite their ethnic, national, sectarian, and stylistic differences, Laila Lalami, Leila Aboulela, Diana Abu-Jaber, Elif Shafak, Randa Jarrar, Shelina Zahra Janmohamed, and Tanaïs articulate Muslimness and western-ness on their own terms, from diverse, distinct, and contradictory positionalities. I have found in this study that these writers are participating in overlapping reconfigurations of Muslimness in contemporary literary imaginations. This literary reimagining of Muslimness, while contesting the biased representations of Muslim identity, mediates and responds to the realities of the twentieth-first century: increasing Islamophobia, anti-immigrant rhetoric, changing modes of citizenship, and destabilization of the fixed notions of home.

This dissertation has situated fiction and literature as the primary conduit of voicing Muslimness as a way of being and acting in the world. However, there are many potential avenues for future academic study of Muslim narratives through the lens of Muslim diaspora space. For one thing, the scope of this study can be extended to various literary and cultural forms of diasporic experience. A close look at the contemporary cultural production of Muslim artists points to an increasing engagement in the deconstructive project of rewriting, remapping, and redefining the dominant hegemonic 
discourse. Other novelists—male, female, and queer—whom I have not had the opportunity to include in this project due to time constraints, (to name a few) Mohsin Hamid, Kamila Shamsie, Fadia Faqir, Ali Eteraz, and Hala Alyan; poets, Ladan Osman, Fatima Asghar, Hanif Abdurraqib, Safia Elhillo, Fatime Diriye; comedians, Hasan Minhaj, Maysoon Zayid, Dean Obeidallah; visual artists and painters, Muna Mire, Mehdi-Georges Lahlou, Helen Zughaib, and Sarah Rahbar all offer a nuanced understanding of Muslim identity marked by distinct lived realities, as well as the reconfiguration of diasporic Muslim subjectivity.

Concomitantly, these contemporary artists of Muslim origin respond to the need to revise thematic and textual limitations that Muslim artists have long encountered as "native informants." Their works, which vary in genre, form, and content, have a common desire to build a bridge of meaningfulness between what it means to be a Muslim and a citizen/resident in the Global North. Painter Helen Zughaib's work, for instance, juxtaposes western motifs with those of Islamic traditions to transgress the dichotomies; Hasan Minhaj overtly places his positionality as an "Indian-American Muslim comedian in America during the Trump Administration" (Minhaj 2018) at the center of his satire. The emerging representations of Muslims in pop-culture, too, with the production of films and TV shows such as "The Bold Type" (2017) and "Ramy" (2019) and with the fusion of musical genres such as Islamic Punk and Hip Hop reveal the formation of a cultural diasporic space where Muslims are actively reclaiming the discourse on Muslimness, defining Muslim identity on their own terms. 
Edited by poets Fatima Asghar and Safia Elhillo, the collection of poetry Halal If You Hear Me (2019) highlights the voices of queer, trans, non-conforming, practicing and non-practicing Muslim women. Asghar and Elhillo write that:

One of the most exciting experiences in reading submissions for this anthology has been in seeing the sheer range of subjects and experiences and tones that Muslims writers write about and in, have always written about and in, every day disproving the fiction coming from both sides that Muslims are a monolith and that there is only one way to be Muslim, one 'right' kind of Muslimness.

(“Compassionate Curating” 2017)

My study has offered the new analytical framework of Muslim diaspora space to bring to light precisely this shift that is already happening in cultural and literary areas. Muslim diaspora space, I have suggested, can be used to better comprehend the literary/cultural practices that are generating a discourse that reimagines a diasporic Muslim subjectivity that is innately diverse, complex, and synchronously Muslim.

I would also like to note that my goal in this project has not been to support, what scholars call, "the liberal caveat," the idea that Muslims' integration depends on their depoliticization. On the contrary, I have explored how writers of Muslim origin manage such stereotypical labels as "fundamentalist," "terrorist," and "oppressed" used to define practicing Muslims - as well as others such as "blasphemous" and "not Muslim enough" used to define Muslims who are considered too liberal — to imbue new meaning into the notion of Muslimness. 
In an attempt to generate more conversations on Muslimness as a lived reality, this project has started with the following interlocking questions: What are some of the ways in which diaspora literature offer alternative visions of Islam and multiple modes of being and belonging? How has the notion of Muslimness informed diasporic literary production? Can new approaches to reading Muslim narratives help migrants and citizens of Muslim origin make sense of the chaos and ongoing shifts that characterize contemporary experience? These scholarly questions, as well as the more difficult ones raised in The Moor's Account (2014), The Kindness of Enemies (2015), Crescent (2003), The Saint of Incipient Insanities (2004), A Map of Home (2007), Minaret (2005), Love in A Headscarf (2009), and Bright Lines (2015) such as Where is home? What is my heritage? Where do I belong? What is my body? and Who defines $m e$ ? have guided my dissertation and still need to be explored further, particularly in relationship to the emerging trends and patterns in the works of literature by writers of Muslim origin. Given the growing trend of Islamophobia and anti-immigration rhetoric in the current sociopolitical climate, such questions about Muslims and Muslim diasporic artistic expression have never been more important. 


\section{Works Cited}

@Fresno_State. “Letter by Fresno State President Joseph I. Castro on the conclusion of the review regarding professor." Twitter, 24 April 2018.

https://twitter.com/Fresno_State/status/988913052572532742. Accessed 15 February 2020.

@LailaLalami. “Today, the NYT frets that, in my book on Spanish conquest, 'Europeans conquer, enslave and erase while Native Americans are a people apart."' Twitter, 5 Sep. 2014, https://twitter.com/LailaLalami/status/507948804977725440. Accessed 26 June 2019.

“A Conversation Between Leila Aboulela and Elnathan John.” Literary Hub, 2 June, 2016, https://ithub.com/on-writing-islamic-identity-and-being-labeled-apolitical-writer/. Accessed 5, Jan. 2019.

Abbas, Sadia. "Leila Aboulela, Religion, and the Challenge of the Novel." Contemporary Literature, vol. 52, no. 3, 2011, pp. 430-461.

Abdel Haleem, M. A. S., translator. The Qur'an: English Translation and Parallel Arabic Text. Oxford UP, 2010.

Abdul-Jabbar, Wissam. “Deconstructing Arab Masculinity in Diana Abu-Jaber's Crescent (2003): The Return of the Unheimlich.” Arab Studies Quarterly, vol. 39, no.1, Winter 2017, pp. 741-17.

Abu-Jaber, Diana. Crescent. W.W. Norton \& Company, 2003.

---. Arabian Jazz. W.W. Norton \& Company, 1993. 
---. Origin. W.W. Norton \& Company, 2007.

---. The Language of Baklava. Anchor Books, 2005.

---. Birds of Paradise: A Novel. W.W. Norton \& Company, 2011.

Aboulela, Leila. The Kindness of Enemies: A Novel. Reprint Ed. Grove Press, 2017.

---. The Translator. Polygon, 1999.

---. Coloured Lights. Polygon, 2001.

---. Minaret. Bloomsbury Publishing, 2005.

---. Lyrics Alley. Grove Press, 2010.

---. Elsewhere, Home. Grove Atlantic, 2018.

---. Bird Summons. Weidenfeld \& Nicolson, 2019.

Ahmed, Leila. A Border Passage: From Cairo to America - A Woman's Journey. Penguin, 2000.

Ahmed, Rehana, et al. Eds. Culture, Diaspora, and Modernity in Muslim Writing. Routledge, 2012.

Ahmed, Shahab. What is Islam? The Importance of Being Islamic. Princeton University Press, 2015. 
Akbar, Arifa. "Back to Khartoum: Leila Aboulela returns to the land of her fathers." Independent,

17 Dec. 2010, https://www.independent.co.uk/arts-entertainment/books/features/back-tokhartoum-leila-aboulela-returns-to-the-land-of-her-fathers-2162261.html. Accessed 15 June 2019.

Akcapar, Sebnem Koser. "Turkish associations in the United States: towards building a transnational Identity.” Turkish Studies, Routledge, vol. 10, no. 2, 2009, pp. 165193.

Al Deek, Akram. Writing Displacement: Home and Identity in Contemporary PostColonial English Fiction. Palgrave MacMillan, 2016.

Al-Joulan, Nayef Ali. “Diana Abu-Jaber’s Arabian Jazz: An Orphic Vision of Hybrid Cultural Identity.” Neophilologus, vol. 94, 2010, pp. 637-652.

Albakry, Mohammed, and Jonathan Siler. "Into the Arab-American Borderland: Bilingual Creativity in Randa Jarrar's 'A Map of Home.”' Arab Studies Quarterly, vol. 34, no. 2, 2012, pp. 109-121.

Alghaberi, Jameel. “The Concept of 'Home' in Palestinian Diaspora Fiction: A Critical Study of Randa Jarrar's Fiction." Langkawi: Journal of The Association for Arabic and English, vol. 4, no. 13, 2018.

Albrecht, Sarah, et al. "Editorial: conceptualizing Muslim diaspora." Journal of Muslims in Europe, vol. 5, 2016, pp. 1-9.

Ali, Ayaan Hirsi. The Caged Virgin. Free Press, 2004.

---. Infidel: My Life. Free Press, 2006. 
Allen, Jeffrey Renard. "His Manifest Destiny." Review of The Moor's Account. The New York Times, 7 Sep. 2014. https://www.nytimes.com/2014/09/07/books/review/themoors-account-by-laila-lalami.html. Accessed 16 May 2018.

Alsultany, Evelyn, and Ella Shohat. Between the Middle East and the Americas: the Cultural Politics of Diaspora. Eds. University of Michigan Press, 2013.

Anderson, Benedict. Imagined Communities: Reflections on the Origin and Spread of Nationalism. 1991. Revised Edition.Verso, 2016.

Appadurai, Arjun. Modernity at large. University of Minnesota Press, 1996.

Ashgar, Fatimah, Safia Elhillo. Eds. Halal If You Hear Me. HaymarketBooks, 2019.

---. "Compassionate curating: editing halal if you hear me." VIDA Women in Literary Arts, 9 March 2017, https://www.vidaweb.org/compassionate-curating-editinghalal-if-you-hear-me/. Accessed 1 Jan. 2019.

Atayurt-Fenge, Zeynep Z. “'This Is a World of Spectacles': Cyclical Narratives and Circular Visionary Formations in Elif Shafak's The Gaze." Critique, vol. 58, no. 3, p. 287.

Awad, Yousef. "Faith, Resilience and the War on Terror in Aboulela's The Kindness of Enemies." International Journal of Arabic-English Studies, vol. 18, 2018, pp. 7190.

Bady, Aaron. "Interview: Laila Lalami.” Post45, 28 Oct. 2014. http://post45.org/2014/10/interview-laila-lalami/ Accessed 15 May 2018. Ba, Mariama. So Long a Letter. Trans. By Bode-Thomas. Heinemann, 1981. 
Badran, Margot. Feminism in Islam: Secular and Religious Convergences. Oneworld Publications, 2009.

Barlas, Asma. "Uncrossed bridges: Islam, Feminism and Secular Democracy." Philosophy and

Social Criticism, vol. 39, 2013, pp. 417-425.

---. “Believing Women” in Islam: Unreading Patriarchal Interpretations of the Qur'an. UT Press, 2002.

Bartyzel, Dorota, Marek Strzelecki. "Poland's Incoming Prime Minister: 'My Dream Is to Re-Christianize the EU.' Bloomberg Politics, 8 Dec. 2017. https://www.bloomberg.com/news/articles/2017-12-08/poland-approves-court-revampbill-scuppering-eu-reboot-chances. Accessed 13 May 2018.

Barrett, Thomas M. "The Remaking of the Lion of Dagestan: Shamil in Captivity." The Russian Review, vol. 53, no. 3, 1994, pp. 353-366.

Bayrakli, Enes, Farid Hafez. Eds. The State of Islamophobia in Europe in 2018. European Islamophobia, Jan. 2018, https://tinyurl.com/EIR2018. Accessed May 2019.

Bell, Chris. "A professor spoke ill of the dead. What happened next?" $B B C N E W S, 29$ July 2019, https://www.bbc.com/news/blogs-trending-47147778. Accessed 14 January 2020.

Bhabha, Homi. The Location of Culture. Routledge, 2004.

---. “The World and the Home.” Social Text, vol. 31, no. 32, 1992, pp. 141-153. 
Bongie, Chris. "Exile on Main Stream: Valuing the Popularity of Postcolonial Literature."

Postmodern Culture, vol. 14, no. 1, 2003, pp. 1-54.

Boccardi, Mariadele. "Introduction: The Novel of History 1969-2005." The Contemporary British Historical Novel. Palgrave Macmillan, 2009. pp. 1-27.

Brouillette, Sarah. Postcolonial Writers in the Global Literary Marketplace. Palgrave, 2007.

Brah, Avtar. Cartographies of Diaspora: Contesting Identities (gender, racism, ethnicity series). Routledge, 1996.

Burwell, Catherine. "Reading Lolita in Times of War: Women's Book Clubs and the Politics of Reception.” Intercultural Education, vol. 18, no. 4, October 2007, pp. 281-296.

Brown, Wendy. "Introduction." Is Critique Secular? Blasphemy, Injury, and Free Speech. Eds. Wendy Brown, Talal Asad, et. al. Fordham Press, 2013. pp. 1-14. Carbajal, Alberto Fernández. Queer Muslim Diasporas in Contemporary Literature and Film. Manchester University Press, 2019.

Clifford, James. "Diasporas." Cultural Anthropology, vol. 9, no. 3, 1994, pp. 302-338. Chambers, Claire. Britain through Muslim eyes. Palgrave Macmillan, 2015.

Chambers, Claire. "Multi-Culti Nancy Mitfords and Halal Novelists: The Politics of Marketing Muslim Writers in the UK." Textus: English studies in Italy, vol. 23, no. 2, 2010, pp. 389-403. 
Chamber, Claire, Caroline Herbert. "Introduction." Imagining Muslims in South Asia and the Diaspora: Secularism, Religion, Representations. Routledge, 2014. pp. $1-14$.

Chittick, William C. Sufism: A Beginner's Guide. Oneworld Publications, 2007.

Clifford, Lisa. "A Conversation with Leila Aboulela." Women in Islam, vol. 1, no. 3 , 2017. Published online, 2019. https://www.womeninislamjournal.com/articles/2019/2/12/zdjullcykf6xgkmsb5cs 5p95b0n1rh Accessed February 2020.

Curiel, Jonathan. "An Arab American writer seeks her identity." SFGATE, 2014, https://www.sfgate.com/entertainment/article/An-Arab-American-writer-seeksher-identity-2773799.php. Accessed 15 June 2019.

Cohen, Robin. Global diasporas: An introduction. UCL Press, 1997.

Connor, Walker. "The Politics of Ethnonationalism.” Journal of International Affairs, vol. 27 , no. 1, 1973, pp. 1-21.

Council on American-Islamic Relations. Anti-Muslim Bias Incidents April - June 2018, CAIR, 2018, https://tinyurl.com/CAIRQ2Report2018. Accessed January 2020,

Davids, Nuraan. "Are Muslim women in need of Islamic feminism? In consideration of a re-imagined Islamic educational discourse.” British Journal of Religious Education, vol. 37, no. 3, 2015, pp. 311-325.

De Sondy, Amanullah. "Why Queer Islamic Studies?” The Scholar and Feminist Online, vol. 2, no. 2, 2017, http://sfonline.barnard.edu/queer-religion/why-queer-islamicstudies/. Accessed 15 February 2020. 
Djelloul, Ghaliya. "Islamic feminism: A contradiction in terms?" Eurozine, 2018. Trans. by Mike Routledge. https://www.eurozine.com/islamic-feminism-contradictionterms/ Accessed 20 September 2019.

De Vaca, Alver Nunez Cabeza. Chronicle of the Narvaez Expedition. Penguin Classics, 2013.

DeLillo, Don. Falling Man. Charles Scribner's Sons, 2007.

Eteraz, Ali. Native believer. Akashic Books, 2016.

Espinoza, Alex. "Taking Down the House: An Interview with Randa Jarrar." ArabAmerica.com, 8 Jan. 2017, https://www.arabamerica.com/taking-houseinterview-randa-jarrar/. Accessed 20 February 2019

Fadda-Conrey, Carol. "Arab American Literature in the Ethnic Borderland: Cultural Intersections in Diana Abu-Jaber's Crescent." MELUS, vol. 31, no. 4, 2006, pp. 187-206.

Fernea, Elizabeth Warnock. In Search of Islamic Feminism: One Woman's Global Journey. Anchor, 1988.

Field, Robin E. "A Prophet in Her Own Town: An Interview with Diana Abu-Jaber." MELUS, vol. 31, no. 4, 2006, pp. 207-25.

Fortier, Anne-Marie. “'Coming Home': Queer Migrations and Multiple Evocations of Home.” European Journal of Cultural Studies, vol.4, no. 4, 2001, pp. 405-424. 
Friedman, Susan. S. Mappings: Feminism and the Cultural Geographies of Encounter. Princeton University Press, 1998.

Fanon, Frantz. Black Skin, White Masks. Grove Press, 2008.

Falkenhayner, Nicole. Making the British Muslim: Representations of the Rushdie Affair and Figures of the War-On-Terror Decade. Palgrave Macmillan, 2014.

Gedro, Julie, Robert C. Mizzi. "Feminist theory and queer theory: implications for HRD research and practice." Advances in Developing Human Resources, vol.16, no. 4, 2014, pp. 445-456.

Geaves, Ron, Theodore Gabriel. Eds. Sufism in Britain. Bloomsbury Academic, 2015.

Geaves, Ron. "Sufism in the West." The Cambridge Companion to Sufism. Ed. Lloyd Ridgeon. Cambridge University Press, 2015.

George, Rosemary M. The Politics of Home: Postcolonial Relocations and Twentiethcentury Fiction. University of California Press, 1999.

Gana, Nouri. "IN SEARCH OF ANDALUSIA: RECONFIGURING ARABNESS IN DIANA ABU-JABER'S CRESCENT.” Comparative Literature Studies, vol. 45, no. 2, 2008, pp. 228-246.

Gore, Clelia. “Open Call for Submissions from Muslim Writers.” Available at: https://cleliagore.com/open-call/, 2017. Accessed 14 May 2018.

Gorman, Anthony, Sossie Kasbarian. Diasporas of the Modern Middle East. Edinburgh University Press, 2015. 
Gross, Terry. “'How To Be A Muslim’ Author On Being A Spokesperson For His Faith.” Fresh Air, NPR, 6 July 2017, https:/www.npr.org/2017/07/06/535757103/howto-be-a-muslim-author-on-being-a-spokesperson-for-his-faith. Accessed 21 April 2019.

Hall, Stuart. "The Spectacle of the 'Other.”' Ed. Stuart Hall. Representation: Cultural Representations and Signifying Practices. Open University, 1997. pp. 223-291. Hall, Stuart. Modernity and Difference. Institute of International Visual Art, 2001.

Hankir, Zahra. "Laila Lalami: 'I Think Evil Needs to Be Called Out." Literary $H u b, 26$ March 2019, https://lithub.com/laila-lalami-i-think-evil-needs-tobe-called-out/. Accessed 29 March 2019.

Hassan, Waïl S. "Leila Aboulela and the Ideology of Muslim Immigrant Fiction.” NOVEL: A Forum on Fiction, vol. 41, no. 2/3, 2008, pp. 298-319.

Hassan, Salah D. "Infinite hijra: migrant Islam, Muslim American literature, and the antimemesis of the Taqwacores.” Eds. Ahmed R., Morey P., Yaqin A., Culture, Diaspora, and Modernity in Muslim Writing. Routledge, 2012.

Hassan, Riaz. "Globalisation's challenge to the Islamic ummah.” Asian Journal of Social Science, vol. 34, no. 2, 2006, pp. 311-323.

Hallenbeck, Cleve. Ed. The Journey of Fray Marcos de Niza. Southern Methodist University Press, 1987. 
Helie, Anissa. "Policing Gender, Sexuality and 'Muslimness." Sexuality in Muslim Contexts: Restrictions and Resistance. Eds. Anissa Helie and Homa Hoodfar. Zed Books, 2012.

Philip, J. Heijmans, Hana de Goei. "European Far-Right Leaders, Meeting to Condemn the E.U., Are Greeted With Boos.” The New York Times, 16 Dec. 2017, https://www.nytimes.com/2017/12/16/world/europe/prague-far-rightconference.html. Accessed 2 Jan. 2020.

Hetzler, Florence M. "The Aesthetics of Ruins: A New Category of Being.” Journal of Aesthetic Education, vol. 16, no. 2, 1982, pp. 105-108.

Hesová, Zora. "Secular, Islamic or Muslim Feminism? The Places of Religion in Women's Perspectives on Equality in Islam." Gender and Research, vol. 20, no. 2, 2019, pp. 26-46.

Hood, Thomas. A Tale of the Harem. E. Moxon, 1871

Huggan, Graham. The Postcolonial Exotic: Marketing the Margins. Routledge, 2001.

Islam, Tanwi N. Bright Lines: A Novel. Penguin, 2015.

---. “Tanaïs.” Tanwinandini.com, 2020, https://www.tanwinandini.com. Accessed 20 March 2020.

Islamic Writers Alliance. Eds. Many Poetic Voices, One Faith. Muslim Writers Publishing, 2009.

Janmohamed, Shelina Zahra. Love in a Headscarf. Aurum Press, 2009.

Jarrar, Randa. A Map of Home. Penguin Books, 2007.

---. Him, Me, and Muhammed Ali. Sarabande Books, 2016. 
Jeffrey, Robin, Sen Ronojoy. Being Muslim in South Asia: Diversity and Daily Life. Oxford Scholarship Online, 2014.

Kahf, Mohja. "Teaching diaspora literature: Muslim American literature as an emerging field." The Journal of Pan African Studies, vol. 4, no. 2, 2010, pp. 163-167.

---. The Girl in The Tangerine Scarf. PublicAffairs, 2006.

Kanwal, Aroosa. "Global Ummah: Negotiating Transnational Muslim Identities." Rethinking Identities in Contemporary Pakistani Fiction. Palgrave Macmillan, 2015.

Kaplan, Caren. Questions of Travel: Postmodern Discourses of Displacement. Duke University Press, 1996.

Khan, Mussarat, Kathryn Ecklund. "Attitudes Toward Muslim Americans Post-9/11." Journal of Muslim Mental Health, vol. vii, no.1, 2012, pp. 1-16.

Kolocotronis, Linda Jamilah. Echoes. Muslim Writers Publishing, 2006.

Kundnani, Arun. The Muslims Are Coming. Verso, 2014. 
Kushkush, Isma'il. "One Foot in Each of Two Worlds, and a Pen at Home in Both." The New York Times, 21 March 2014, https://www.nytimes.com/2014/03/22/world/africa/one-foot-in-each-of-twoworlds-and-a-pen-at-home-in-both.html. Accessed 18 June 2019.

Kuortti, Joel. Writing Imagined Diasporas: South Asian Women Reshaping North American Identity. Cambridge Scholars Publishing, 2007.

Král, Françoise. Critical Identities in Contemporary Anglophone Diasporic Literature. Palgrave, 2009.

Kramatschek, Claudia. “Interview with Kamila Shamsie: A Dark Chapter in Pakistan's History." Qantara, 23 Oct. 2009, https://en.qantara.de/content/interview-withkamila-shamsie-a-dark-chapter-in-pakistans-history. Accessed 15 May 2019.

Lalami, Laila. "Writing Muslims.” Religion \& Literature, vol. 43, no. 1, Spring 2011, pp. 144-148.

---. Hope and Other Dangerous Pursuits. Algonquin Books, 2005.

---. Secret Son. Algonquin Books, 2009.

---. The Moor's Account. Pantheon, 2014.

---. The Other Americans: A Novel. Vintage, 2019.

Landau, Jacob M. "Diaspora nationalism: The Turkish case.” The Call of the Homeland: Diaspora Nationalisms, Past and Present. Eds. Allon G., Athena S. L., \& Smith, A.D. Brill, 2010. pp. 219-240 
Lipka, Michael. Muslims and Islam: Key findings in the U.S. and around the world. Washington, DC: Pew Research Center, 2017.

Atef, Laouyene. "Politics of the Exotic in Diana Abu-Jaber's Crescent." Critique: Studies in Contemporary Fiction, vol. 56, no. 5, 2015, pp. 586-601.

McDonald, Alison. “A Conversation with Elif Shafak.” Otium, vol. 2, no.1, April 2005, http://www.elifsafak.us/en/roportajlar.asp?islem=roportaj\&id=2. Accessed 24 March 2019.

Macdonald, Kate. "Interview with Laila Lalami, author of The Moor's Account." KateMacdonald.net, 21 Aug. 2015, https://katemacdonald.net/2015/08/21/interview-with-laila-lalami-author-of-themoors-account/. Accessed 13 June 2018.

Michael, Magali Cornier. "Arabian Nights in America: Hybrid Form and Identity in Diana Abu-Jaber's Crescent." Critique: Studies in Contemporary Fiction, vol. 52, no. 3, 2011, pp. 313-331.

Mandaville, Peter. Transnational Muslim Politics: Reimagining the Umma. Routledge, 2001.

McEwan, Ian. Saturday. Jonathan Cape, 2005.

Minhaj, Hasan. Interviewed by Monica Bushman for The Frame, KPCC. 20 April 2018. Modood, Tariq. Still Not Easy Being British: struggles for a multicultural citizenship. Trentham Books, 2010.

Mahmood, Saba. Politics of Piety: The Islamic Revival and the Feminist Subject. Princeton University Press, 2012. 
Malak, Amin. Muslim Narratives and the Discourse of English. State University of New York Press, 2004.

Mbe, Vikas S. “A Conversation with Elif Shafak.” Thoughteconomics, 1 May 2019, https://thoughteconomics.com/elif-shafak/. Accessed 15 May 2019.

Meer, Nasar, Tariq Modood. "Refutations of Racism in the 'Muslim Question'” Patterns of Prejudice, vol. 43, no. 3-4, 2009, pp. 335-354.

Mernissi, Fatima. Beyond the Veil: Male-female Dynamics in Modern Muslim Society. Indiana University Press, 1987.

Metcalf, Barbara D. Ed. Making Muslim Space in North America and Europe. University of California Press, 1996.

Moghissi, Haideh, et al. Eds. Diaspora by Design: Muslims in Canada and Beyond. University of Toronto Press, 2009.

Moghissi, Haideh. "Introduction." Muslim Diaspora: Gender, Culture and Identity. Routledge, 2006.

Mohamed, Besheer. New estimates show U.S. Muslim population continues to grow. Washington, DC: Pew Research Center, 2018.

Moghul, Haroon. How to Be a Muslim: An American Story. Penguin Random House, 2017. Morey, Peter, Amina Yaqin. Framing Muslims: Stereotyping and Representation After 9/11. Harvard University Press, 2011. 
Morey, Peter. Islamophobia and the Novel. Columbia University Press, 2018.

Mostafa, Gadal-Ha M. "Correcting the image of Islam and Muslims in the West: Challenges and Opportunities for Islamic Universities and Organizations.” Journal of Muslim Minority Affairs, vol. 27, no. 3, 2007, pp. 371-386.

Moslund, Sten Pultz. Migration Literature and Hybridity. Palgrave MacMillan, 2010.

Nash, Geoffrey. Writing Muslim Identity. Continuum, 2012.

Nasta, Susheila. Home Truths: Fictions of the South Asian Diaspora in Britain. Palgrave Macmillan, 2001.

Nordin, Irene Gilsenan, et al. "Introduction.” Transcultural Identities in Contemporary Literature. Brill | Rodopi, 2013.

Oh, Ingyu. "Rethinking Borders in Japan: Internal, Cultural, and Geopolitical." CrossCurrents: East Asian History and Culture Review, vol. 18, no. 1, 2016, pp. 85-95.

Pardoe, Julia S. H. The Romance of the Harem. Henry Colburn, 1839.

Peumans, Wim. Queer Muslims in Europe: Sexuality, Religion and Migration in Belgium. Bloomsbury Publishing, 2018.

Pickersgill, Jeannette. Tales of Harem. Longman, Rees, Orme, Brown, And Green, 1827. Rahnema, Saeed. "Islam in Diaspora and Challenges to Multiculturalism.” Ed. Moghissi. Muslim Diaspora: Gender, Culture and Identity. Routledge, 2006.

Rahman, Momin. Homosexualities, Muslim Cultures and Modernity. Palgrave Macmillan, 2014.

Ramadan, Tariq. "The Future of the New 'We." Harvard International Review, vol. 35, no. 1, 2013, pp. 14-18. 
Roy, Oliver. Globalized Islam. Columbia University Press, 2004.

Saeed, Amna, Fatima Zain. “Texts within Text: An Intertextual Study of Elif Shafak's The Forty Rules of Love." NUML Journal of Critical Inquiry, vol. 16, no. 1, 2017, pp. $29-45$.

Said, Edward. Orientalism. Vintage, 1979.

---. "Traveling Theory." The World, the Text, and the Critic. Reprint edition. Harvard University Press, 1983.

Saint-Blancat, Chantal. "Une diaspora musulmane en Europe?” Archives des sciences soci-ales des religions, vol. 92, no. n.a., 1995. pp. 9-24.

---. "Islam in Diaspora: Between Reterritorialization and Extraterritoriality." International Journal of Urban and Regional Research, vol. 26, no. 1, 2002, pp. $138-151$.

Safran, William. "Diasporas in Modern Societies: Myths of Homeland and Return." 1991. The Routledge Diaspora Studies Reader. Eds. Klaus Stierstorfer and Janet Wilson. Routledge, 2018. pp. 2-5. 
Santesso, Esra. Disorientation: Muslim Identity in Contemporary Anglophone Literature. Palgrave Macmillan, 2013.

Seedat, Fatima. "Islam, Feminism, and Islamic Feminism: Between Inadequacy and Inevitability." Journal of Feminist Studies in Religion, vol. 29, no. 2, Fall 2013, pp. $25-45$.

Selby, Jennifer A. “'Muslimness' and Multiplicity in Qualitative Research and in Government Reports in Canada." Critical Research on Religion, vol. 4, no. 1, 2016, pp. 72-89.

Seyhan, Azade. Writing Outside the Nation. Princeton University Press, 2001.

Schumann, Christopher. “A Muslim 'Diaspora' in the United States?” The Muslim World, vol. 97, no. n.a, 2007, pp.: 67-76.

Shafak, Elif. The Saint of Incipient Insanities. Farrar, Straus \& Giroux, 2004.

---. Forty Rules of Love. Penguin, 2009.

---. The Gaze. Penguin, 2000.

---. The Bastard of Istanbul, Viking Press, 2006/

---. 10 Minutes 38 Seconds in This Strange World. Viking Press, 2019.

Shamsie, Kamila. Home Fire: A Novel. Riverhead, 2017.

Sheffer, Gabriel. Diaspora Politics: at Home Abroad. Cambridge University Press, 2003.

---. "Transnationalism and Ethnonational Diasporism.” Diaspora, vol. 15, no. 1, 2006. 
Simbar, Reza. "Political Islam and International System: Impacts and Implications." Journal of International Area Studies, vol.16, no. 2, 2009, pp. 107-123.

Simon, Alissa. "Mythology, Taboo and Cultural Identity in Elif Shafak's The Bastard of Istanbul." Postcolonialist, vol. 2, no. 2, 2015, pp. 111.

Slessor, Catherine. "Reading the ruins." The Architectural Review, 21 Dec. 2017, https://www.architectural-review.com/essays/reading-the-ruins/10026503.article. Accessed 12 May 2019.

Smale, Alison. "Marine Le Pen Extols Far Right During Speech in Germany." The New York Times, 21 Jan. 2017, https://www.nytimes.com/2017/01/21/world/europe/marine-le-pen-extols-farright-during-speech-in-germany.html. Accessed 15 Feb. 2018.

Smith, Cassander L. "Beyond the Mediation: Esteban, Cabeza de Vaca's Relación, and a Narrative Negotiation.” Early American Literature, vol. 47 no. 2, 2012, p. 267291.

Spivak, Gayatri. "Can the Subaltern Speak?” Marxism and the Interpretation of Culture. Eds.

C. Nelson and L. Grossberg. Macmillan Education, 1988. pp. 271-313.

Stotesbury, John A. "Genre and Islam in Recent Anglophone Romantic Fiction.” Refracting the Canon in Contemporary British Literature and Film. Eds. Susana Onega and Christian Gutleben. Rodopi, 2004. pp. 69-82

Takim, Liyakat. "Shi'ism in the American Diaspora: Challenges and Opportunities." Journal of Muslim Minority Affairs, vol. 38, no. 1, 2018, pp. 73-86. 
TBMM Turk Ceza Kanunu. Turkish Criminal Code.

https://www.tbmm.gov.tr/develop/owa/kanunlar_gd.durumu?kanun_no=5237, 2004.

“Tell MAMA’s Annual Report for 2017 Shows Highest Number of Anti-Muslim Incidents." Faith matters, 22 July 2018, https://tellmamauk.org/tell-mamasannual-report-for-2017-shows-highest-number-of-anti-muslim-incidents/. Accessed 15 Aug. 2019.

“Tell MAMA Annual Report 2018: Normalising Hatred.” Faith Matters, 2 Sep. 2019. https://tellmamauk.org/tell-mama-annual-report-2018-_-normalising-hate/. Accessed 13 Feb. 2020.

“The Impact of Christchurch Terror Attack | Tell MAMA Interim report 2019." Faith Matters, 12 March 2020, https://tellmamauk.org/the-impact-of-the-christchurchterror-attack/. Accessed 27 March 2020.

Tölölyan, Khachig. "The Nation State and Its Others: In Lieu of a Preface." Diaspora, vol. 1, no.1, 1991, pp. 3-7.

Updike, John. The Terrorist. Alfred A. Knopf, 2006.

Wadud, Amina. Qur'an and Woman: Rereading the Sacred Text from a Woman's Perspective. Oxford University Press, 1999.

Werbner, Pnina. "Introduction: the Materiality of Diasporas between Aesthetics and 'Real' Politics." Diaspora, vol. 9, no.1, 2000, pp. 5-20. 
---. "Theorising Complex Diasporas: Purity and Hybridity in the South Asian Public Sphere in Britain." Journal of Ethnic and Migration Studies, vol. 30, no. 5, 2004, pp. 895-911.

West, Keon, Joda Llyod. "The Role of Labeling and Bias in the Portrayals of Acts of ‘Terrorism': Media Representations of Muslims vs. Non-Muslims.”Journal of Muslim Minority Affairs, vol. 37, no. 2, 2017, pp. 211-222.

White, Paul. "Introduction." Writing across Worlds: Literature and Migration.

Eds. King R., Connell J. \& White P. Routledge, 1995.

Yadlin, Rivka. "The Muslim Diaspora in the West." Middle Eastern Minorities and Diasporas. Eds. Moshe Ma‘oz, Gabriel Sheffer. Sussex Academic Press, 2002.

Yazıcıŏglu, Özlem Ögüt. "Who is the Other? Melting in the Pot in Elif Shafak's The Saint of Incipient Insanities and The Bastard of Istanbul." Litera, vol.2, no. 2, Dec. 2009.

Young, Robert J.C. Colonial Desire: Hybridity in Theory, Culture and Race. Routledge, 1995.

---. Torn Halves: Political Conflict in Literary and Cultural Theory. Manchester UP, 1996.

Zine, Jasmin. "Lost in Translation: Writing Back from the Margins." Journal of Feminist Studies in Religion, vol. 24 no. 1, 2008, pp 110-116.

---. "Creating a Critical Faith-Centered Space for Antiracist Feminism: Reflections of a Muslim Scholar-Activist.” Journal of Feminist Studies in Religion, vol. 20, no. 2, 2004, pp. 167-187. 
Born and raised in Istanbul, Turkey, Neriman Kuyucu has developed a passion for interdisciplinary approaches to literature. She holds M.A. degrees in English and Cultural Studies from University of Michigan-Flint where she worked on a thesis project that documented Hemingway's experiences in Turkey. Her doctoral work focuses on migration and diaspora literature. Her research examines the ways in which the cultural/literary production of the Muslim Middle Eastern/South Asian/North African diasporas can contribute to the notions of Muslim diaspora. 
